$8 / x^{1}+n^{3}$
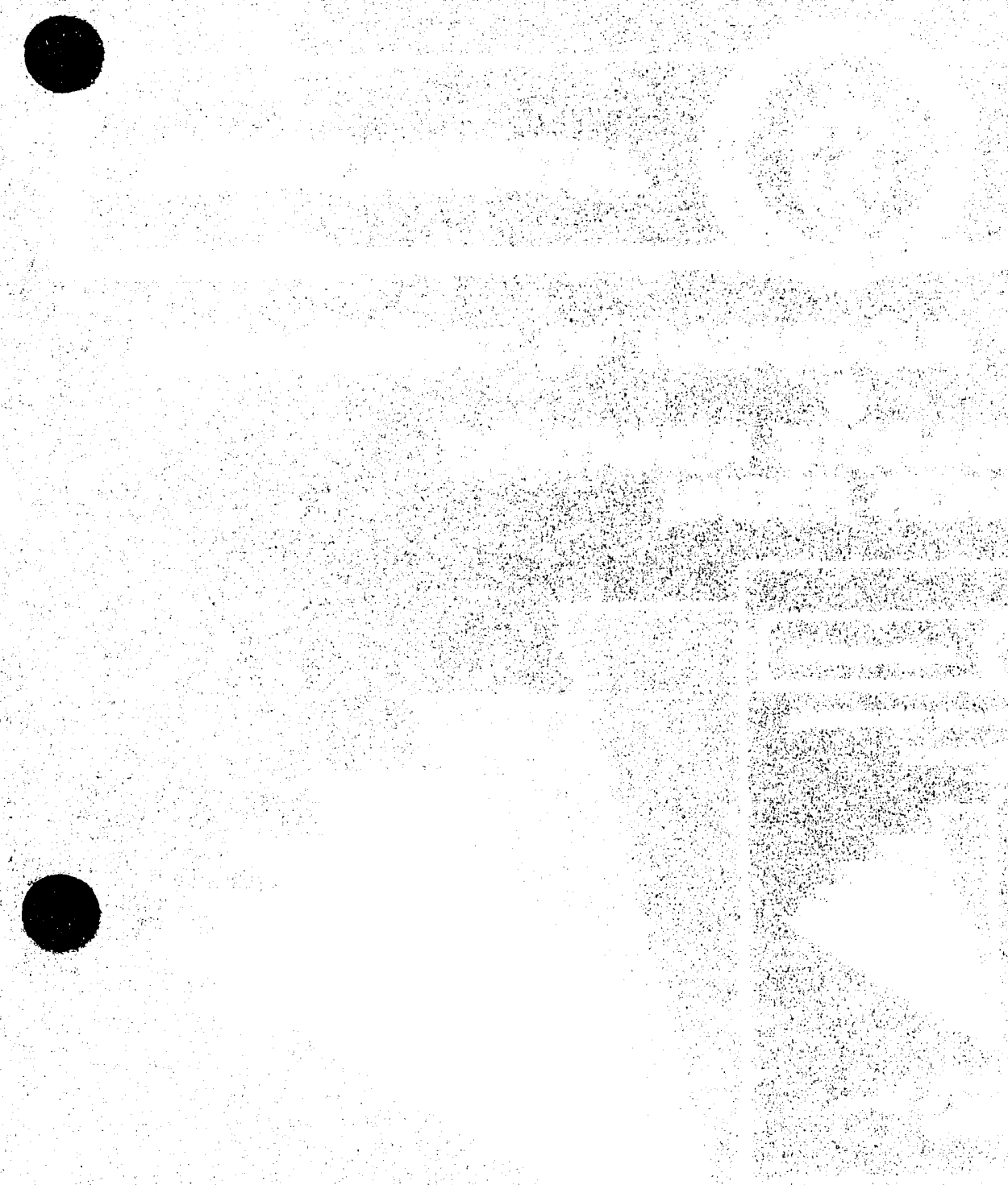


\section{ENVIRONMENTAL}

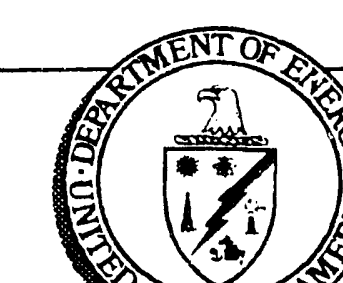

GUIDANCE

\section{MANAGEMENT OF HAZARDOUS WASTE CONTAINERS \&}

\section{CONTAINER STORAGE AREAS UNDER RCRA}

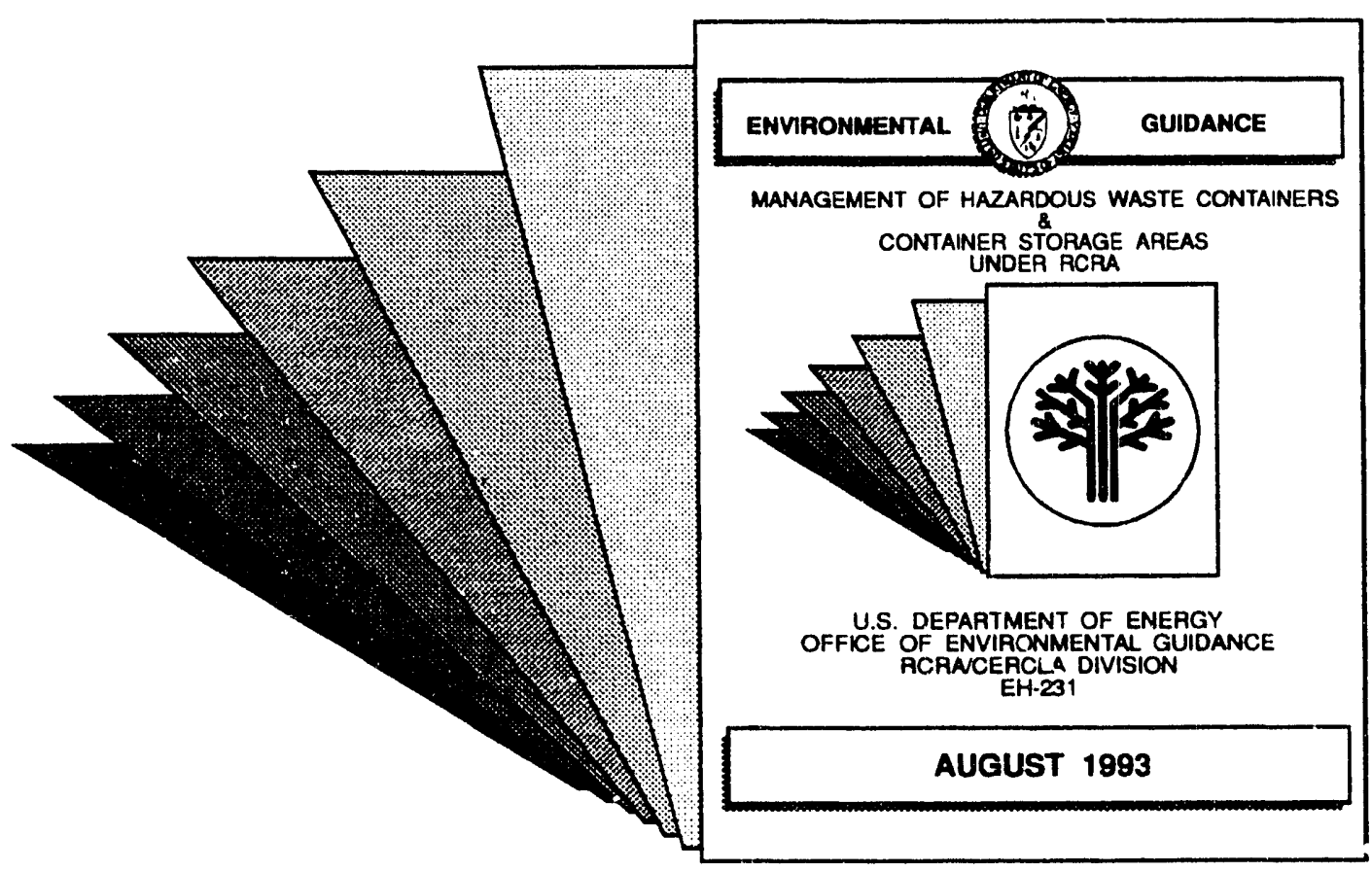

\section{U.S. DEPARTMENT OF ENERGY}

OFFICE OF ENVIRONMENTAL GUIDANCE RCRA/CERCLA DIVISION

EH-231

\section{AUGUST 1993}


DATE: August 3, 1993

REPLY TO ATTN OF

Office of Environmental Guidance:Coalgate:6-6075

SUBuECT: Management of RCRA Hazardous Waste Containers and Container Storage Areas

To: Distribution

The purpose of this memorandum is to provide Program Offices and Field Organizations with a copy of a guidance document entitled: Management of RCRA Hazardous Waste Containers and Container Storage Areas, developed by the Office of Environmental Guidance, RCRA/CERCLA Division (EH-231).

The approach taken in this guidance document is graphical and utilizes tables, flowcharts, and narrative text to provide a "roadmap" to Resource Conservation and Recovery Act (RCRA) hazardous waste container and container storage area requirements under 40 CFR 264/265 Subpart I (Use and Management of Containers) for permitted and interim status facilities, respectively. The guidance consists of five chapters which address RCRA standards applicable to hazardous and radioactive mixed waste container management at DOE facilities. The standards addressed include requirements for: (1) container storage facility design and construction; (2) management of hazardous and radioactive mixed waste containers (i.e., labeling and marking, inspection, segregation of incompatible wastes, etc.); (3) requirements for response to, and remediation of, releases from containers and container storage areas, and (4) closure and post-closure care of container storage areas.

It should be noted that this guidance is not intended to be used alone. Rather, it should be used in tandern with Federal and State regulations and other technicallyoriented guidance documents to plan and institute effective management practices for RCRA hazardous and radioactive mixed waste containers and container storage areas at DOE facilities.

In preparing the subject guidance document, EH-231 distributed a draft version of the guidance to selected Program Offices and Field Organizations for review and comment. Comments received have been addressed in preparing the final document, and we believe that the input provided by the reviewers has improved the utility, applicability, and quality of this guidance document. EH-231 wishes to extend its appreciation to those DOE elements that reviewed the draft document and provided comments for consideration in the development of the final guidance. 
Questions pertaining to RCRA container and container storage area requirements in general, or the attached guidance in particular, should be directed to Jerry Coalgate of my staff at (202) 586-6075.

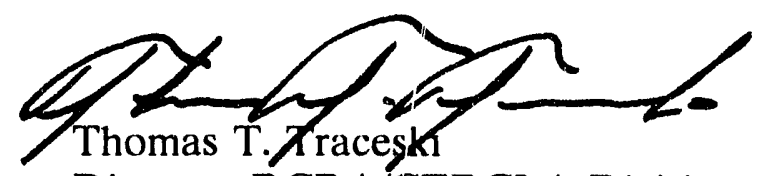

Director, RCRA/CERCLA Division

Office of Environmental Guidance

Attachment 


\section{Program Omces}

O.J. Lawrence, CE-64 Al Knight, CP-20

Henry Garson, DP-3.2

Lake Barrett, DP-6.1

Dan Rhoades, DP-6.2

Charles Halsted, DP-27

Donald Knuth, DP-60

Thomas Evans, DP-62

Fritz Wolff, DP-624

John Ford, DP-63

Karl Goodwin, DP-636

Richard Hahn, DP-64

Randy Lynch, DP-643

Ralph Hagan, DP-644

Ken Ferlic, DP-65

M. Whitaker, DR-1

Lynne Fairobent, EH-1

Joe Fitzgerald, EH-30

Harry Pettengill, EH-40

Rick Jones, EH-41

Richard Moore, El-23.1

Jim Disbrow, El-523

Paul Grimm, EM-2

Tom Elsasser, EM-4

Ellen Livingston-Behan, EM-5

Willis Bixby, EM-6

Randal Scott, EM-20

Jill Lytle, EM-30

Jim Turi, EM-33

Lee Stevens, EM-331

Mark Frei, EM-34

Joseph Coleman, EM-35

Jay Rhoderick, EM-351

Kent Hancock, EM-352

John Tseng, EM-36

Jack Baublitz, EM-40

Jim Fiore, EM-42

Bill Wisenbaker, EM-43

Sally Mann, EM-44

Mark Stahr, EM-441

Ralph Lightner, EM-45

J. A. Ahlquist, EM-452

Clyde Frank, EM-50

Tom Evans, EM-53

Larry Weiner, EM-60

Kitty Gandee, EM-62

Don Donaldson, EM-121

David Moses, EP-63

James Farley, ER-8.2

Frederick Koomanoff, ER-10

Albert Evans, ER-13

Sat Goel, ER-14

David Goodwin, ER-20.1

Omer Goktepe, ER-22

Joseph McGrory, ER-23

John Yates, ER-42

Steven Rossi, ER-53

William Osburn, ER-73

Robert Wood, ER-74

James Carney, ER-912

Craig Zamuda, FE-6

N. L. Johnson, FE-33

Mark Matarrese, FE-64

David Jewett, FE-222

Hal Delaplane, FE-423

William Dennison, GC-11

Charles Bradley, NE-33

Charles Thompson, NE-43

Raj Sharma, NE-47
Robert Gisch, NE-60

Jim Fairobent, OE-11

Joanna Stancil, PA-3

Steve Brocoum, RW-22

Dwight Shelor, RW-30

D. M. Valentine, RW-332

Gerald Parker, RW-333

A.G. Joseph, ST-30

Rodney Adelman, WDC

\section{Field Omces}

N. S. Dienes, Albuquerque Operations Office P.M. Ramey, Albuquerque Operations Office Rich Sena, Albuquerque Operations Office

C. L. Soden, Albuquerque Operations Office

R. E. Sabre, Albuquerque Operations Office

Mike Butler, Brookhaven Area Office

D.J. Cook, Central Training Academy, AL

M. Flannigan, Chicago Operations Office

Joel Haugen, Chicago Operations Office

J. Hunze, Chicago Operations Office

T. J. Rowland, Fernald Office

G. Westerbeck, Fernald Office

Jerry Lyle, Idaho Operations Office

Gerald C Bowman, Idaho Operations Officee

Walt Sato, Idaho Operations Office

Peggy Hinman, Idaho Operations Office

Bruce Church, Nevada Operations Office

Don Elle, Nevada Operations Office

Joe Fiore, Nevada Operations Office

Jim Magruder, Nevada Operations Office

Steve Mellington, Nevada Operations Office

J. D. Ross, Nevada Operations Office

Rodney R. Nelson, Oak Ridge Operations Office

H. Wayne Hibbitts, Oak Ridge Operations Office

Robert Sleeman, Oak Ridge Operations Office

Peter Gross, Oak Ridge Operations Office

L.K. Price, Oak Ridge Operations Office

Larry Radcliff, Oak Ridge Operations Office

Don Alexander, Richland Operations Office

J. Bauer, Richland Operations Office

Rudy Guercia, Richland Operations Office

R.D. Izatt, Richland Operations Office

Bob Holt, Richland Operations Office

Leo Little, Richland Operations Office

J. Hartman, Rocky Flats Office

Frazer Lockhart, Rocky Flats Office

Tom Lukow, Rocky Flats Office

Al Pauole, Rocky Flats Office

Mark Van Derpuy, Rocky Flats Office

E. Ballard, San Francisco Operations Office

J. Cullen, San Francisco Operations Office

Jim Davis, San Francisco Operations Office

Alex Dong, San Francisco Operations Office

Joe Juetten, San Francisco Operations Office

Terry Vaeth, San Francisco Operations Office

'Thomas Heenan, Savannah River Operations Office

Lou Goidell, Savannah River Operations Office

A.B.Gould, Savannah River Operations Office

Lenard Sjostrom, Savannah Operations Office

M.G. O'Rear, Savannah River Operations Office

Steve Wright, Savannah River Operations Office

R. B. Provencher, West Valiey Project Office

Rob Waldman, Alaska Power Administration

Alex Crawley, Bartlesville Project Office

Thomas Wesson, Bartlesville Project Office

Alexandra Smith, Bonneville Power Administration, A

Thru: BPA, RM 8 G033

John Ganz, Morgantown Energy Technology Center

Joseph Martin, Morgantown Energy Technology
Center

Jim Killen, Naval Petroleum Reserves in California D. Miles, Naval Petroleum Reserves in Wyoming, Utah, \& Colorado, Casper, WY

Melvin Keller, Pittsburgh Energy Technology Center

Earl Shollenberger, Pittsburgh Naval Reactors Office, Thru: NE-60

Andrew Seepo, Schenectady Naval Reactors Office, Thru: NE-60

Jim Lloyd, Southeastern Power Administration

Don Hayes, Southwestern Power Administration

Melissa Smith, Strategic Petroleum Reserve Project Management

Office

Vicki Ponce, Western Power Administration

Gerald Johnson, Manager, Amarillo Area Office

(AAO)

Larry D. Kirkman, Manager, Dayton Area Office (DAO)

Earl Bean, Manager, Kansas City Area Office (KCAO)

Kathleen Carlson, Manager, Kirtland Area Office (KAO)

Jerry Bellows, Acting Manager, Los Alamos Area Office (LAAO)

Richard E. Glass, Manager, Pinellas Area Office (PAO)

J. E. Solecki, Manager, Grand Junction Project Office

Arlen Hunt, Waste Isolation Pilot Plant Project Office (WIPP-AL)

James Mewhinney, WIPP Project Office (WIPP-AL)

A. R. Chernoff, Jr., Project Manager, Uranium Mill Tailings

Remedial Action Project Office

Kathleen Grassmeir, Yucca Mountain Project Office

W.R. Miller, Special Projects Manager, ES\&H Division, Morgantown, WV

Paul K. Kearns, Manager, NREL, Golden Office

Jeff Baker, NREL, Golden Office

Nat Brown, SSCPO

\section{cc: Other Oreanizations}

National Low-Level Waste Management Program, EG\&G Idaho Hazardous Waste Remedial Action Program, (HAZWRAP) Remedial Action Program Information Center 


\title{
Management of Hazardous Waste Containers and Container Storage Areas \\ under the Resource Conservation and Recovery Act
}

\author{
AUGUST 1993 \\ Prepared by \\ U.S. DEPARTMENT OF ENERGY \\ OFFICE OF ENVIRONMENTAL GUIDANCE \\ RCRA/CERCLA DIVISION \\ (EH-231) \\ Washington, D.C. \\ Technical support by \\ ICF, Incorporated \\ $\&$ \\ Pacific Northwest Laboratory
}




\begin{abstract}
DOE's Office of Environmental Guidance, RCRA/CERCLA Division, has prepared this guidance document to assist waste management personnel in complying with the numerous and complex regulatory requirements associated with RCRA hazardous waste and radioactive mixed waste containers and container management areas. This document is designed using a systematic graphic approach that features detailed, step-by-step guidance and extensive references to additional relevant guidance materials. Diagrams, flowcharts, references, and overview graphics accompany the narrative descriptions to illustrate and highlight the topics being discussed. Step-by-step narrative is accompanied by flowchart graphics in an easy-to-follow, "roadmap" format.
\end{abstract}




\section{TABLE OF CONTENTS}

SECTION

$\underline{\text { PAGE }}$

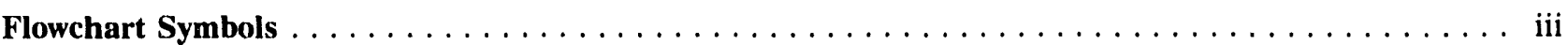

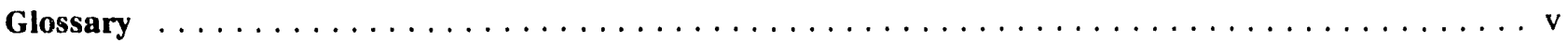

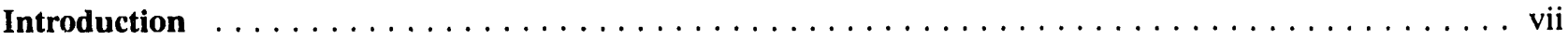

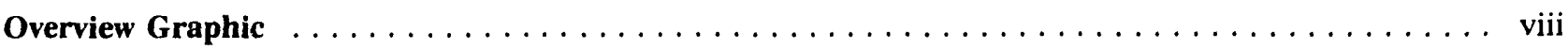

MODULE 1: APPLICABILITY

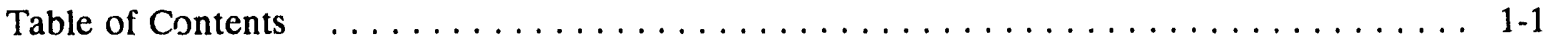

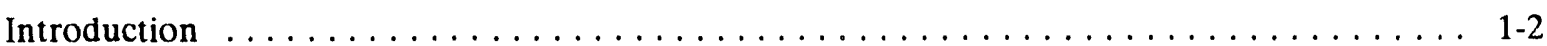

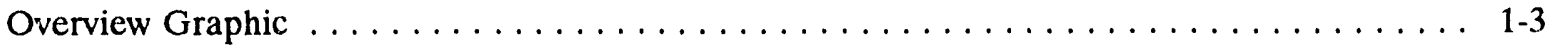

Submodule 1.1 - What is a RCRA Hazardous Waste

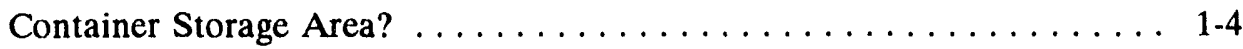

Submodule 1.2 - What Requirements Apply to RCRA

Container Storage Areas? . . . . . . . . . . . . . . . 1-10

\section{MODULE 2: CONTAINER FACILITY DESIGN AND CONSTRUCTION}

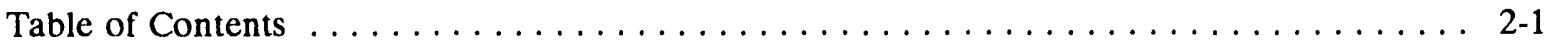

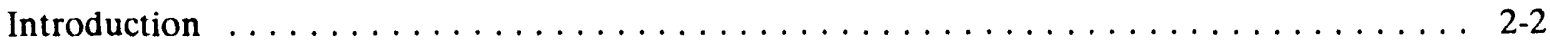

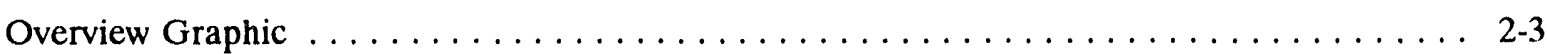

Submodule 2.1 - General Container Facility Design and

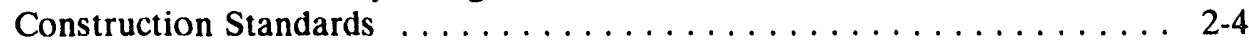

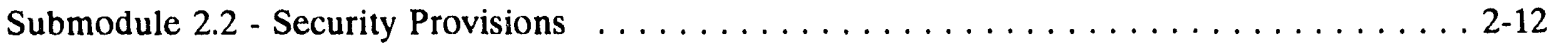

Submodule 2.3 - Permitting . . . . . . . . . . . . . . . . . . . . . . . 2-14

\section{MODULE 3: MANAGEMENT OF CONTAINERS}

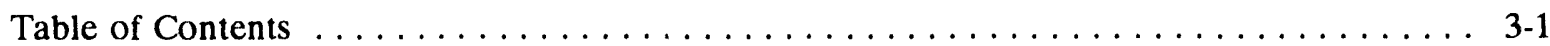

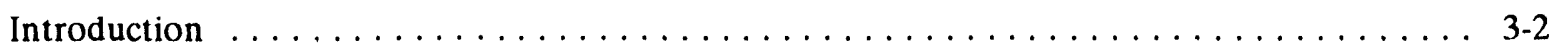

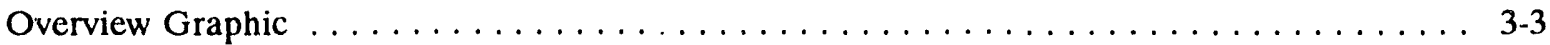

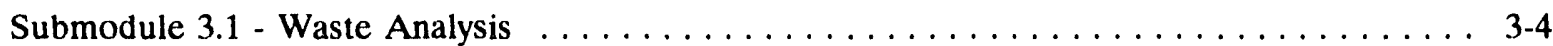

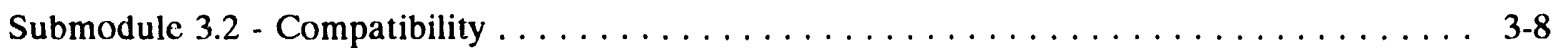




\section{TABLE OF CONTENTS (Continued)}

SECTION

$\underline{\text { PAGE }}$

Submodule 3.3 - General Container Management Practices $\ldots \ldots \ldots \ldots \ldots \ldots \ldots \ldots$ 3-12

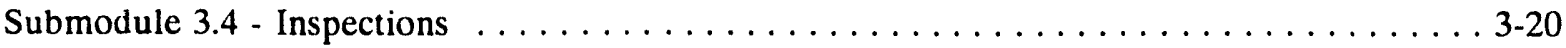

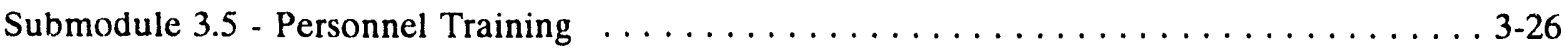

Submodule 3.6 - Manifesting and Recordkeeping $\ldots \ldots \ldots \ldots \ldots \ldots \ldots \ldots \ldots \ldots \ldots \ldots \ldots$

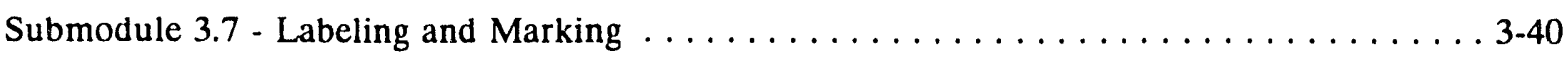

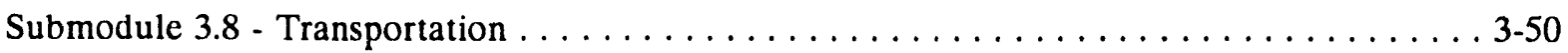

MODULE 4: EMERGENCY PREPAREDNESS, RESPONSE, AND REMEDIATION

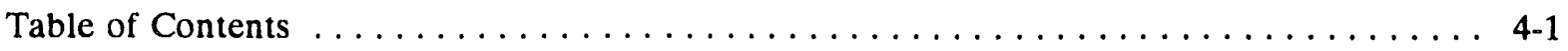

Introduction $\ldots \ldots \ldots \ldots \ldots \ldots \ldots \ldots \ldots \ldots \ldots \ldots \ldots \ldots \ldots \ldots \ldots \ldots \ldots \ldots \ldots \ldots \ldots, 2$

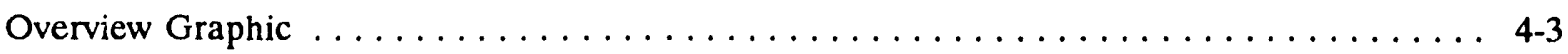

Submodule 4.1 - Release Detection and Reporting $\ldots \ldots \ldots \ldots \ldots \ldots \ldots \ldots \ldots \ldots$

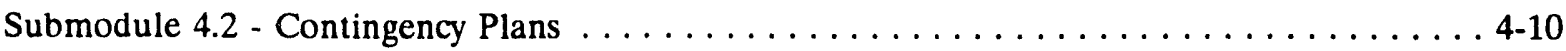

Submodule 4.3 - Spill Response $\ldots \ldots \ldots \ldots \ldots \ldots \ldots \ldots \ldots \ldots \ldots \ldots \ldots \ldots \ldots$ 4-14

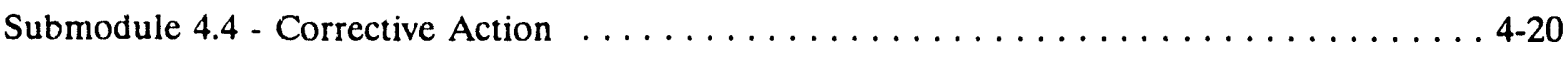

MODULE 5: CLOSURE

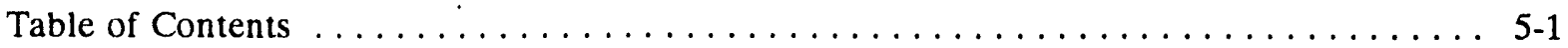

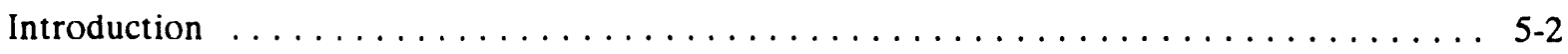

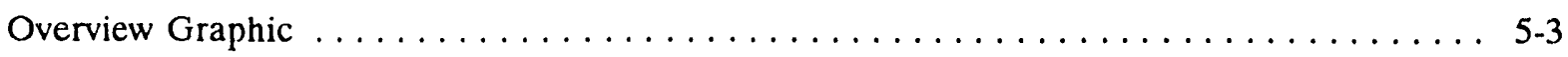

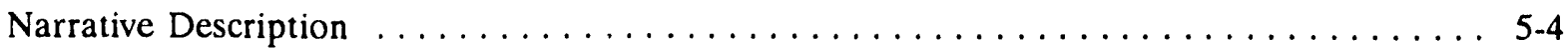

Attachment A - RCRA Container Regulations $\ldots \ldots \ldots \ldots \ldots \ldots \ldots \ldots \ldots \ldots \ldots \ldots \ldots \ldots$ 


\section{FLOWCHART SYMBOLS}

This document as a graphical guidance document, utilizes flowcharts and other graphic techniques to accompany and illustrate the narrative descriptions. The flowcharts employ certain symbols, as highlighted below.

Ovals represent the beginning of a new flowchart.

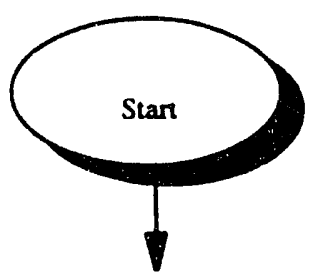

- Unshaded Rectangles indicate actions that must be completed. Follow the directions contained in the unshaded rectangles.

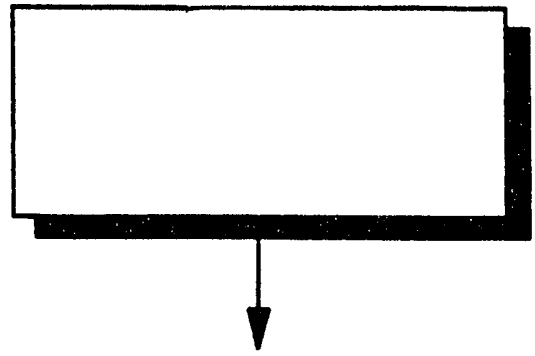

- Diamonds represent decision points. Answer the question (either Yes or No) contained in the diamond and follow the appropriate path.

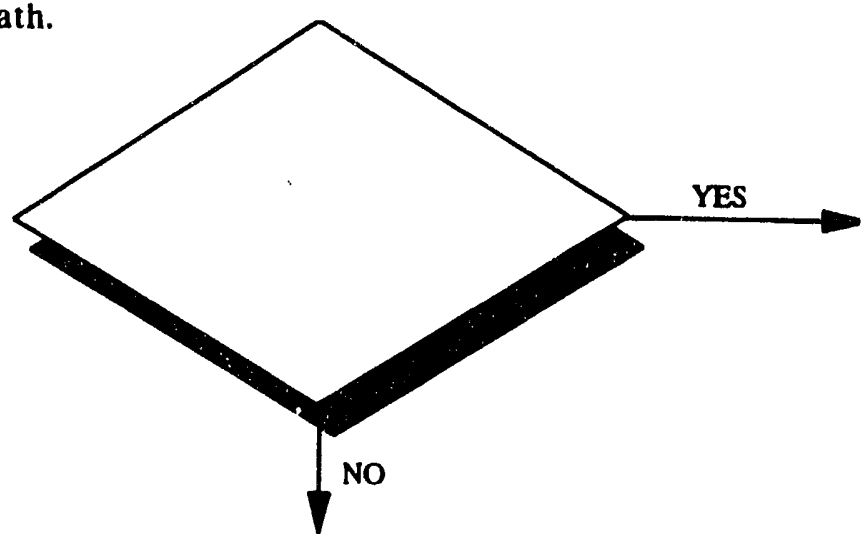

- Shaded Rectangles contain directional statements (i.e., "continued on," "continued from," or "go to" statements). Follow any directional statements to or from the appropriate steps within the guidance. 
Note Boxes contain additional guidance in performing the actions outlined in the flowchart.

$$
\text { Note: }
$$

- Submodule Headings are used to label sections of the flowchart.

- Flowchart Step Numbers are intended to assist DOE personnel in cross-referencing the flowchart and the accompanying narrative guidance. 


\section{GLOSSARY}

The glossary contains brief definitions of some important terms used in this document. In some cases, these definitions are derived from very complicated regulatory terms. For more detailed definitions, consult the regulatory citations given in parentheses.

Active life The period from the initial receipt of hazardous waste at a facility until the Regional Administrator receives certification of final closure (40 CFR 260.10).

Acutely hazardous waste Hazardous wastes that have been identified as being extremely toxic and/or extremely reactive $(261.33(\mathrm{e}))$.

Characteristic waste A solid waste defined as hazardous because it exhibits one or more of the following characteristics: ignitability, corrosivity, reactivity or toxicity (40 CFR 261 Subpart C).

Closure The process in which the owner/operator of a hazardous waste management facility discontinues active operation by treating, removing from the site, or disposing of on-site, all hazardous wastes in accordance with an approved closure plan (40 CFR 264 and 265 Subpart G).

Conditionally exempt small quantity generator A facility that generates less than $100 \mathrm{~kg} / \mathrm{month}$ of hazardous waste and less than $1 \mathrm{~kg} /$ month of acutely hazardous waste is exempt from full regulation under Subtitle $C$, subject to certain conditions regarding the types, amounts, treatment and disposal of wastes (40 CFR 261.5).

Container Any portable device in which material is stored, transported, treated, disposed of, or otherwise handled (40 CFR 260.10).

Container storage area The area in which containers are stored (40 CFR 264 and 265 Subpart I).

Containment system A system of dikes, barriers, walls, drains, etc, designed to contain leaks and spills from containers. For containers holding liquids, this system must have sufficient capacity to contain ten percent of the volume of all containers or the volume of the largest container, whichever is greater (40 CFR 264.175).

Contingency plan A document describing an organized, planned, and coordinated course of action to be followed in case of a fire, explosion or release of hazardous waste constituents which could threaten human health or the environment (40 CFR 260.10).

Corrective action The process whereby owner/operators of hazardous waste treatment, storage, or disposal facilities (TSDFs) are required to detect and, if necessary, address releases of hazardous constituents from their facilities to environmental media (40 CFR 264.100 and 264.101).

Facility All contiguous land, and structures, other appurtenances, and improvements on the land, used for treating, storing, of disposing of hazardous waste. A facility may consist of several treatment, storage, or disposal units (e.g., one or more landfills, surface impoundments) (40 CFR 260.10).

Generator Any person, by site, whose process produces a hazardous waste or whose actions first cause a hazardous waste to become subject to regulation (40 CFR 260.10).

Hazardous waste A waste is considered hazardous if it is listed in Subpart D of Part 261 "Lists of Hazardous Wastes" or if it exhibits any of the following characteristics: (1) ignitability; (2) corrosivity; (3) reactivity; and (4) toxicity (40 CFR 261.3). 
Interim status The period during which the owner/operator of an existing TSDF is treated as having been issued a RCRA permit even though a final permit determination has not been made (40 CFR 270.10).

Leachate Any liquid, including any suspended comnonents in the liquid, that has percolated through or drained from hazardous waste (40 CFR 260.10).

Listed Waste A solid waste that is defined as hazardous because it is specifically listed in Subpart D of 40 CFR Part 261 (40 CFR 261 Subpart D).

Manifest An official EPA document (EPA Form 8700-22 and if necessary, continuation sheet EPA Form 8700-22A) containing information regarding the type, quantity and origin of hazardous waste that allows waste to be tracked from the point of its generation to the point of its ultimate disposal (40 CFR 260.10).

Permit An authorization, license or equivalent control document issued by EPA or a State allowing a TSDF to operate (40 CFR 270 Subpart A).

Placard Placards are placed on the outside of vehicles used in transporting containers of hazardous waste off-site. Placards identify and provide warning of the hazards associated with the waste (e.g., radioactive, corrosive, combustible, dangerous) (49 CFR 172 Subpart F).

Post-Closure The period following closure of a hazardous waste management facility during which the owner/operator must continue to secure the facility sufficiently to protect human health and the environment. The standard post-closure care period for hazardous waste is $\mathbf{3 0}$ years

(40 CFR 264 and 265 Subpart G).

Regulated unit Any surface impoundment, waste pile, land treatment unit, or landfill that received hazardous waste after July 26, 1982 (40 CFR 264.90).

Satellite accumulation Accumulation of hazardous waste at the point of generation that does not exceed 55 gallons (40 CFR 262.34).

Solid waste Any garbage, refuse, sludge or other waste materials, except: domestic sewage and any mixture of other wastes that pass through a sewer system to a publicly owned treatment works, industrial wastewater discharges that are point source discharges subject to regulation under the amended Clean Water Act, irrigation return flows, source, special, nuclear, or byproduct materials defined by the Atomic Energy Act of 1954, and in situ mining materials (40 CFR 261.2).

Solid waste management unit (SWMU) Waste management units from which hazardous wastes or constituents may migrate, even if the unit was not intended for the management of hazardous waste, along with any areas that become contaminated as a result of routine and systematic releases of wastes (55 FR 30808).

Tank A stationary device, designed to contain an accumulation of hazardous waste, which is constructed primarily of non-earthen material (e.g., wood, plastic, concrete, steel). (Note: This guidance manual applies only to containers, not tanks) (40 CFR 260.10).

Waste characterization A process in which the owner/operator of a TSDF, or possibly the generator, obtains a detailed chemical and physical analysis of the hazardous wastes to be handled at a facility (40 CFR 264.13 and 265.13). 


\section{INTRODUCTION}

U.S. Department of Energy (DOE) facilities manage millions of gallons of hazardous and radioactive mixed waste in container storage areas. These storage areas and their associated containers must be managed in accordance with all applicable Federal, State, and local environmental regulations, including the Resource Conservation and Recovery Act (RCRA) as amended by the Hazardous and Solid Waste Amendments (HSWA) of 1984. RCRA establishes standards for hazardous waste from the time it is generated to the time of its ultimate disposal. These "cradle to grave" regulations are codified in Title 40 of the Code of Federal Regulations (CFR).

Specific RCRA regulations applicable to hazardous and radioactive mixed waste containers and container storage units are located in 40 CFR 264 Subpart I and 40 CFR 265 Subpart I for permitted and interim status facilities, respectively. Subpart I requirements for both permitted and interim status facilities contain provisions for: ensuring that containers are in good condition (e.g., not rusting, not containing any apparent structural defects, not leaking); container handling; inspections; containment system design and operation; compatible, reactive, or ignitable wastes; and closure. In addition to the unitspecific requirements, waste managemer. personnel managing these facilities must comply with the general hazardous waste management practices contained in Subparts B through E of Parts 264 and 265 and general closure requirements of Parts 264 and 265 Subpart G. Waste management personnel also must be aware of RCRA procedures for identifying hazardous waste (40 CFR Part 261), requirements for generators and transporters of hazardous waste (Parts 262 and 263), as well as permitting requirements (Part 270).

Regulations promulgated under RCRA, as well as DOE Orders, DOT and OSHA regulations, the Emergency Planning and Community Right-to-Know Act (EPCRA), and a host of State and local regulations all potentially affect operations at hazardous and radioactive mixed waste container storage areas.

To assist waste management and environmental oversight personnel in complying with these numerous and complex regulatory requirements, DOE's Office of Environmental Guidance,

RCRA/CERCLA Division, has prepared this guidance document on management of RCRA hazardous and radioactive mixed waste container storage areas. The document is designed using a systematic graphic approach that features detailed, step-by-step guidance and extensive references to additional relevant guidance materials. Diagrams, flowcharts, references, and overview graphics accompany the narrative descriptions to illustrate and highlight the topics being discussed. The graphics (e.g., flowcharts) also accompany the step-by-step, narrative descriptions in an easy-to-follow, "roadmap" format.

\section{HOW TO USE THIS GUIDANCE DOCUMENT}

This document is composed of modules and submodules. Each module represents a major component of container storage facility requirements at DOE facilities. Each submodule discusses a particular aspect of these broad requirements. For example, the overall container management requirements of Module 3 are divided into submodules discussing issues such as inspections, compatibility, and manifesting. This document is designed so that each module and/or submodule can be used independently. For example, those responsible for or interested in training requirements could look solely at Submodule 3.5, "Personnel Training." Personnel should refer to other sections when necessary, but each submodule and module provide thorough and accurate guidance individually for the relevant regulations. The submodules will reference other submodules, when necessary, to ensure that waste management and environmental oversight personnel receive all pertinent information. This cross-referencing eliminates narrative redundancy, enables each submodule to act as a stand-alone document, and ensures that the information on a topic is thorough and complete. 


\section{OVERVIEW OF GRAPHIC GUIDANCE PACKAGE}
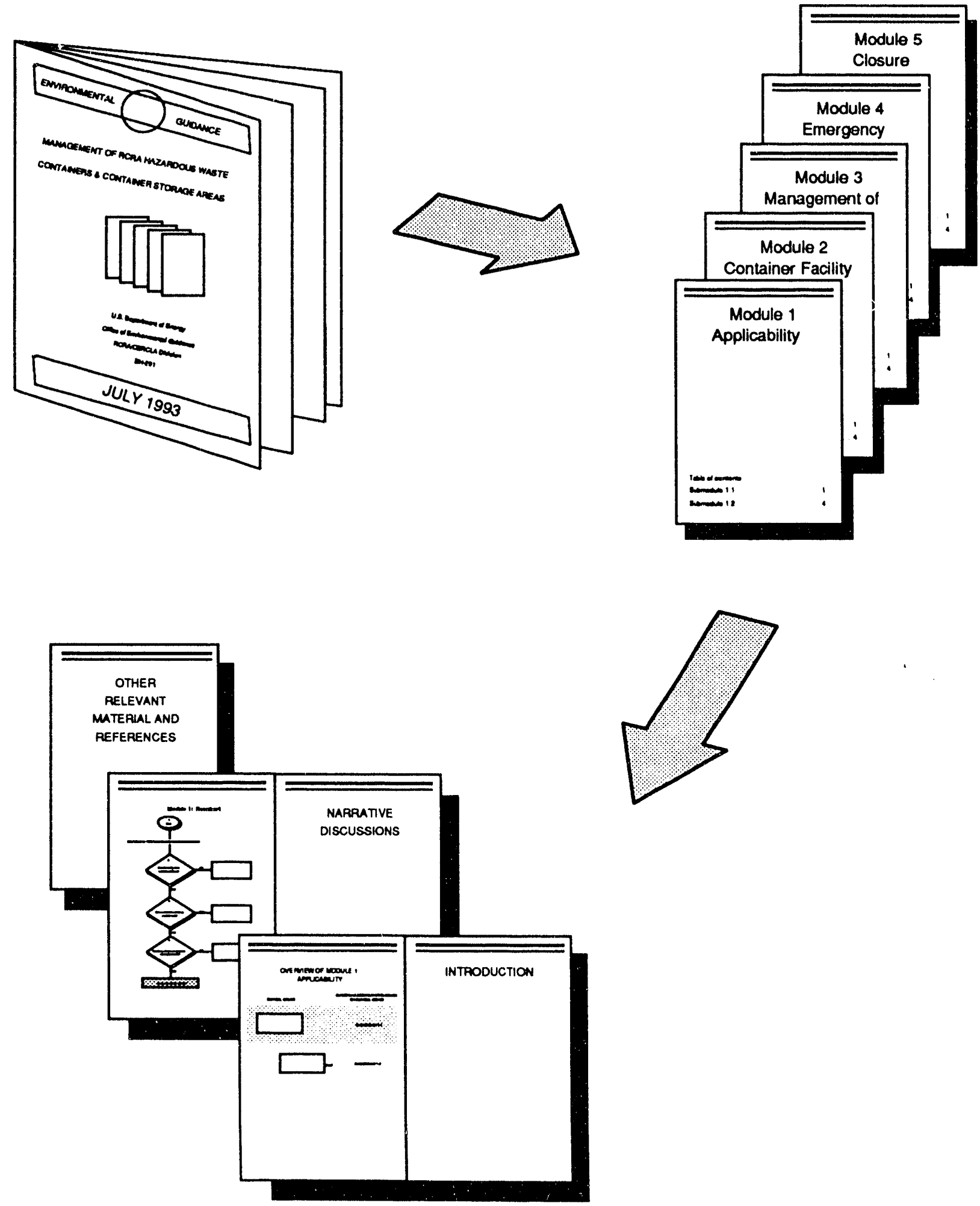


\section{PURPOSE OF THIS GRAPHIC GUIDANCE DOCUMENT}

DOE should use this guidance document as:

- an overview of the regulations for RCRA hazardous and radioactive mixed waste container storage areas;

- a comprehensive step-by-step guidance for operating procedures of a container storage area, from design and construction standards to closure and corrective action requirements; and

- a quick, ready-reference guide for any specific topic concerning container storage area operation.

\section{ADDITIONAL REQUIREMENTS}

This guidance is intended to be used in addition to, not in lieu of, requirements in specific Federal facility agreements (FFAs), and Federal, State, and local regulations affecting container storage areas. Waste management and environmental oversight personnel should be aware that additional requirements may apply to their facilities. These additional requirements include:

- DOE Orders - Line management personnel are responsible for complying with all applicable DOE orders. Circumstances at specific DOE sites may trigger requirements in addition to those required by Federal container storage area requirements.

- applicable State and local requirements - Line management personnel are responsible for complying with applicable State requirements and are encouraged to cooperate fully with State and local authorities.

- $\quad$ regulatory change - EPA may expand or modify existing requirements. Line management personnel should verify that they are using the most up-to-date reference materials.

- Federal facility agreements - Line management personnel should review FFAs or other such agreements that may effect how container storage area requirements are implemented.

\section{OVERVIEW OF MODULES}

Module 1, "Applicability" - discusses the most basic elements of container management issues (i.e., what constitutes a container, and when is a container considered to be empty).

Module 2, "Container Facility Design and Construction" - describes requirements relevant to the container storage area, such as containment system construction and storage capacity, aisle spacing, security systems, and permitting standards.

Module 3, "Management of Containers" - describes requirements that are relevant to the containers themselves such as compatibility, inspections, waste handling, manifesting, labeling, marking, transportation issues.

Module 4, "Emergency Preparedness, Response, and Remediation" - addresses issues such as release detection and reporting requirements under RCRA and CERCLA, spill response, and corrective. action that may or may not occur over the operating life of a container storage area.

Module 5, "Closure" - discusses requirements for ceasing operations at a container storage area. 


\section{STRUCTURE OF THE MODULES AND SUBMODULES}

Each module consists of a table of contents, an overview graphic, and several submodules, in most cases. The overview graphic demonstrates how the module fits into the overall container and container area management process, and outlines the submodules, where applicable. Each submodule contains a flowchart, an accompanying narrative description of the requirements, and references to relevant regulations and materials. Several submodules also contain additional useful guidance materials (e.g., checklists, sample labels, manifests, and diagrams). 


\section{MODULE 1}

\section{APPLICABILITY}

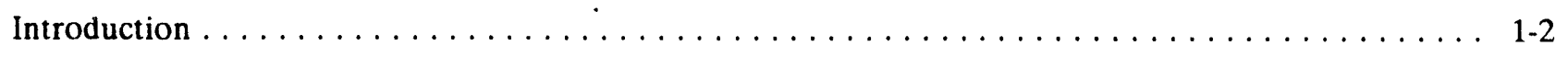

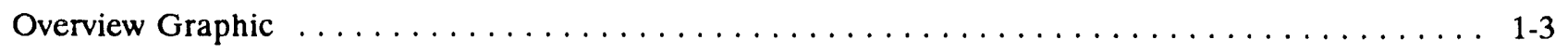

Submodule 1.1 - What is a RCRA Hazardous Waste Container Storage Area? . . . . . . . . 1-4

Submodule 1.2 - What Requirements Apply to RCRA Container Storage Areas? . . . . . . . 1-10 


\section{Introduction to Module 1: Applicability}

This module provides guidance on determining which Federal requirements apply to DOE facilities managing hazardous waste in containers and container storage areas. Line management personnel should use this module to:

- identify what constitutes a container;

- $\quad$ determine the types of waste (e.g., hazardous and radioactive mixed waste) that are subject to RCRA requirements and those that are subject to other requirements (e.g., medical waste);

- deterinine whether or not a container is empty and thus exempt from regulation;

- understand the impacts of applicable requirements on the quantity of waste accumulated and accumulation time; and

- $\quad$ understand the effects of State authorization and permitting status on regulation and management of container storage areas.

The following flowchart and accompanying narrative guide the reader step-by-step through the applicable requirements for container storage areas. 


\section{OVERVIEW OF MODULE 1: APPLICABILITY}

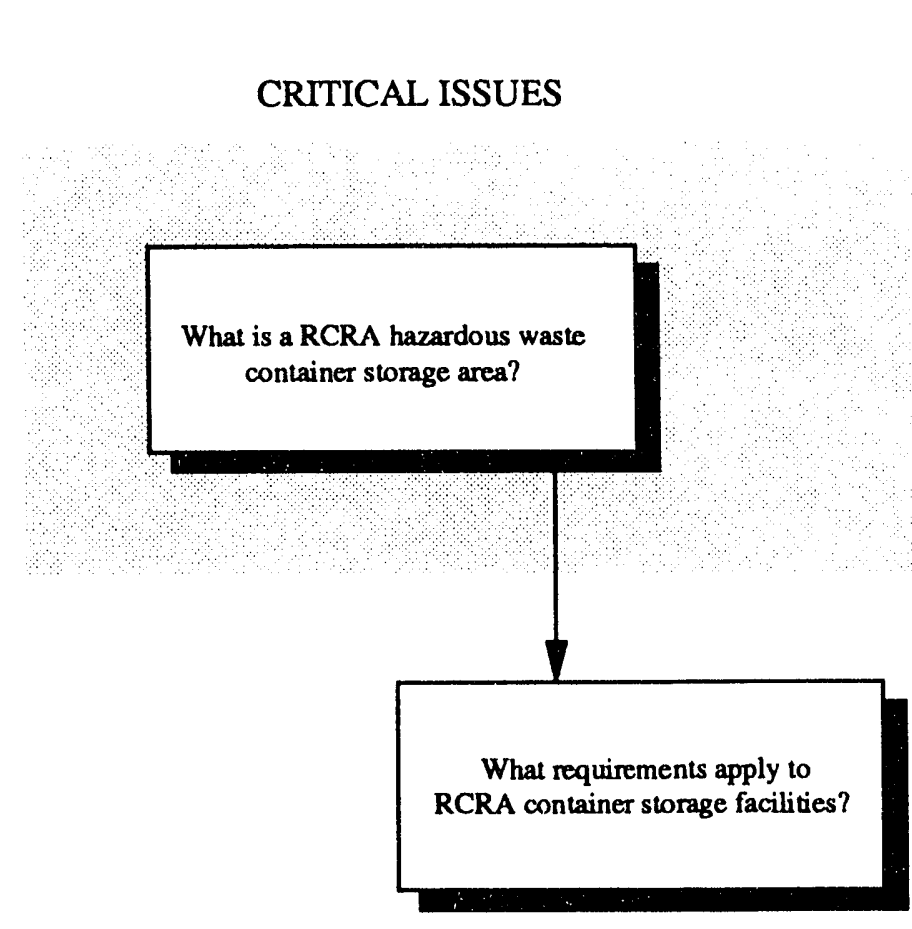

SUBMODULES CONTAINING GUIDANCE

ON CRITICAL ISSUES

SUBMODULE 1.1

SUBMODULE 1.2 


\section{Module 1: Flowchart}

\section{SUBMODULE 1.1: WHAT IS A RCRA HAZARDOUS WASTE CONTAINER STORAGE AREA?}

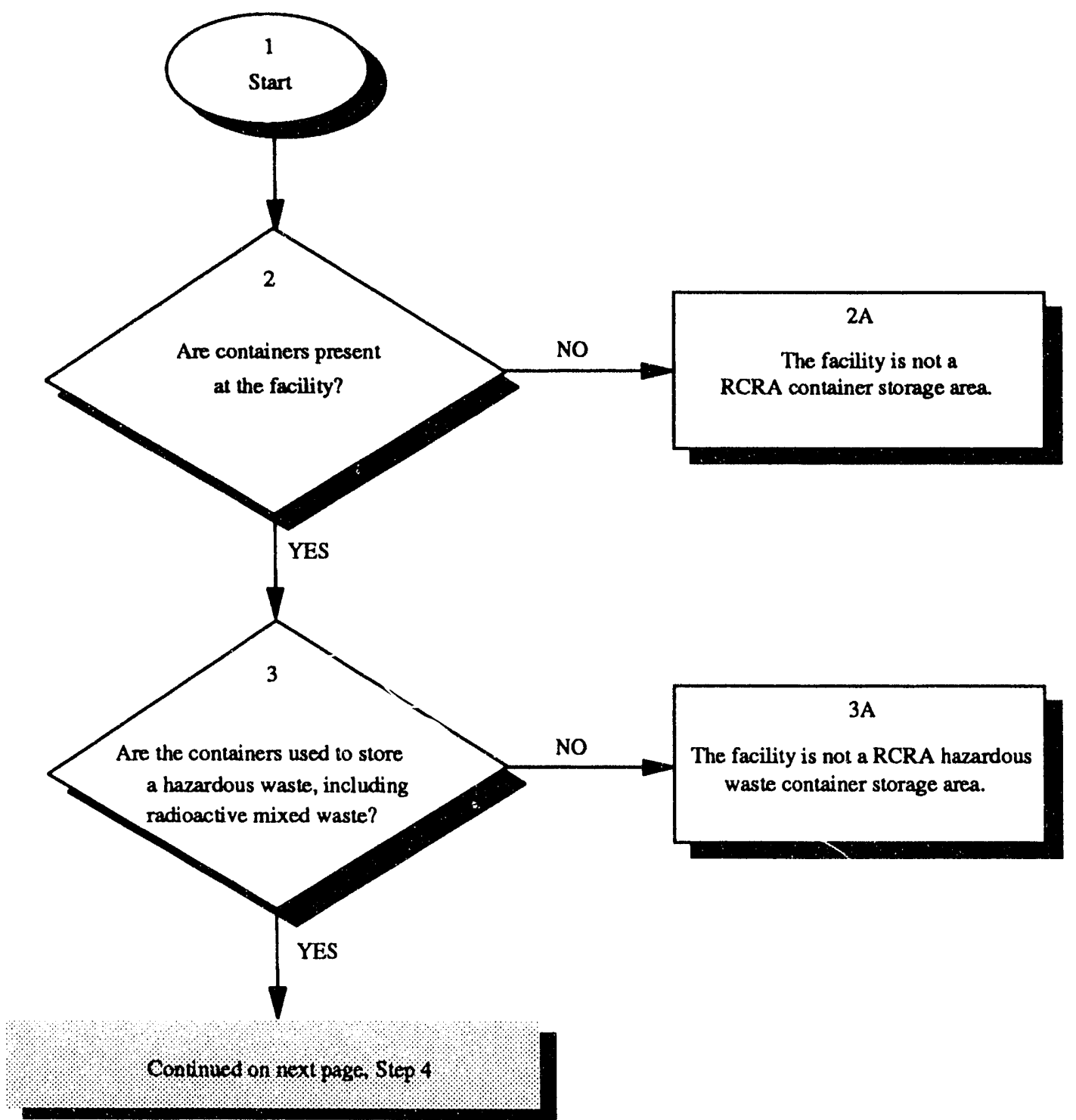




\section{SUBMODULE 1.1: WHAT IS A RCRA HAZARDOUS WASTE CONTAINER STORAGE AREA?}

Step $1 \quad$ Start.

Step 2 A container is defined as "any portable device in which a material is stored, transported, treated, disposed of, or otherwise handled" (40 CFR 260.10). According to the EPA RCRA Hotline (703-920-9810), mobility determines what constitutes a container. For example, a container may be a 1,000-gallon tank with wheels that is initially used to accumulate waste and is later moved to transfer the waste to a storage unit. However, if the tank were mounted on legs and affixed to the ground, it would be considered a tank, not a container. The most common types of containers used by waste management personnel are 55-gallon drums and barrels. Other examples of containers include 5-gallon carboys, retention tanks, overpack or salvage drums, and wood and metal boxes of assorted sizes.

Step 2A This document provides guidance on areas used to store or accumulate RCRA hazardous waste in containers. It does not discuss specific requirements that do not pertain in RCRA hazardous waste containers or container storage areas.

Step 3 Waste management personnel must next determine, using a two-step process, whether the waste being handled in a container is a hazardous waste. First, they must determine whether it is a solid waste. Note that substances such as raw materials and products that are not defined as solid waste (because, for example, they have not been thrown away, discarded, or served their intended purpose) are not subject to RCRA requirements, even if they are stored in a container. Other materials excluded from regulation under RCRA because they are not defined as solid waste include (40 CFR 261.4(a)):

- domestic sewage;

- $\quad$ Clean Water Act point-source discharge;

- $\quad$ source, special nuclear, or by-product material (Note: if these radioactive materials are mixed with hazardous waste, the hazardous component is subject to regulation under RCRA Subtitle C);

- $\quad$ irrigation return flow; and

- $\quad$ in-situ mining waste.

Guidance on determining whether a material is a solid waste can be found in $40 \mathrm{CFR}$ 261.2. EH-231 guidance on the definition of solid and hazardous waste is currently under development. (Definitions of Solid and Hazardous Wastes under RCRA, U.S. Department of Energy, Office of Environmental Guidance, RCRA/CERCLA Division, Graphic Guidance, DOE/EH-0273, August 1992. If waste management personnel determine that the material is a solid waste, then the next step is to determine whether the waste is a hazardous waste. A waste is considered hazardous if it is listed in Subpart D of Part 261 "Lists of Hazardous Wastes" or if it exhibits any of the following hazardous waste characteristics: (1) ignitability, (2) corrosivity, (3) reactivity, or (4) toxicity. Note that any residue remaining in a container or inner liner removed from a container that held any commercial chemical product identified in 40 CFR 261.33(e) or (f) becomes a hazardous waste when discarded, unless the container is defined as empty in 40 CFR 261.7(b).

Step 3A

If waste management personnel determine that the waste is not hazardous, the requirements outlined in the remainder of this document are not applicable. 


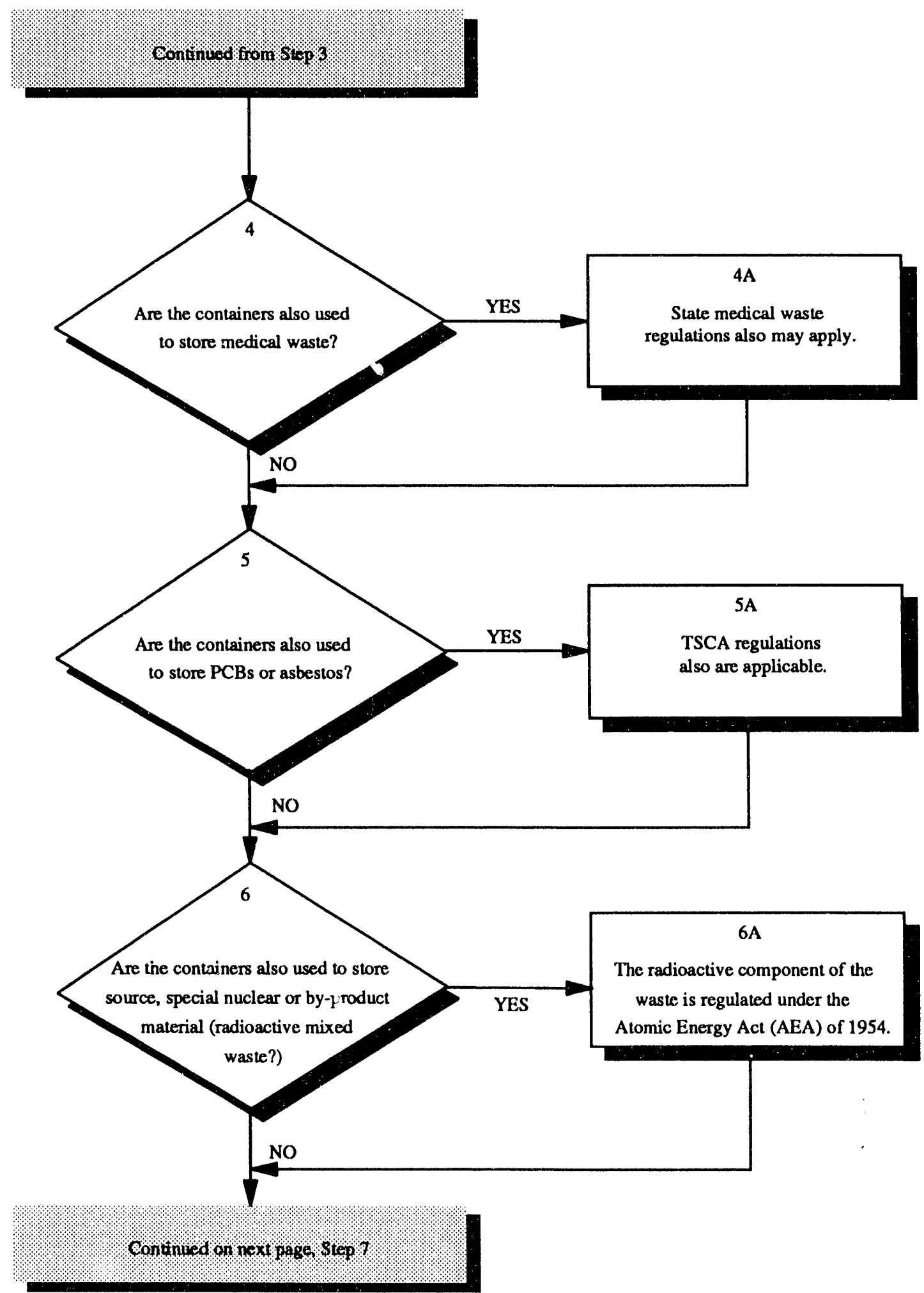


EPA currently lists seven classes of medical waste. These are: (1) cultures and stocks (e.g., culture dishes, swabs, infectious agents); (2) human pathological wastes (e.g., body parts); (3) human blood and blood products; (4) used sharps (i.e., needles, syringes, scalpel blades); (5) animal wastes (e.g., carcasses, body parts, bedding); (6) isolation wastes (e.g., materials contaminated by humans isolated to protect others from highly communicable diseases); and (7) unused sharps (54 FR 12326).

Step 4A Primary responsibility for regulation of medical wastes lies with the States. Waste management personnel should consult appropriate State regulations. On November 1, 1988, the Medical Waste Tracking Act (MWTA) was signed into law. MWTA required the EPA to establish a two-year demonstration program for tracking medical wastes generated in States subject to the demonstration program. Information regarding EPA's two-year demonstration program for medical wastes can be found in 54 FR 12326, March 14,1989 , or in the following:

- Managing and Tracking Medical Wastes - A Guide to the Fedtral Program for Generators, U.S. Environmental Protection Agency, EPA 530-SW-89-021, September 1989;

- Managing and Tracking Medical Wastes - A Guide to the Federal Program for Treatment, Destruction, and Disposal Facilities, U.S. Environmental Protection Agency, EPA 530-SW-989-023, September 1989; and

- Managing and Tracking Medical Wastes - A Guide to the Federal Program for Transporters, U.S. Environmental Protection Agency, EPA 530-SW-89-022, September 1989.

Step 5

Step 5A

Step 6

Step 6A 


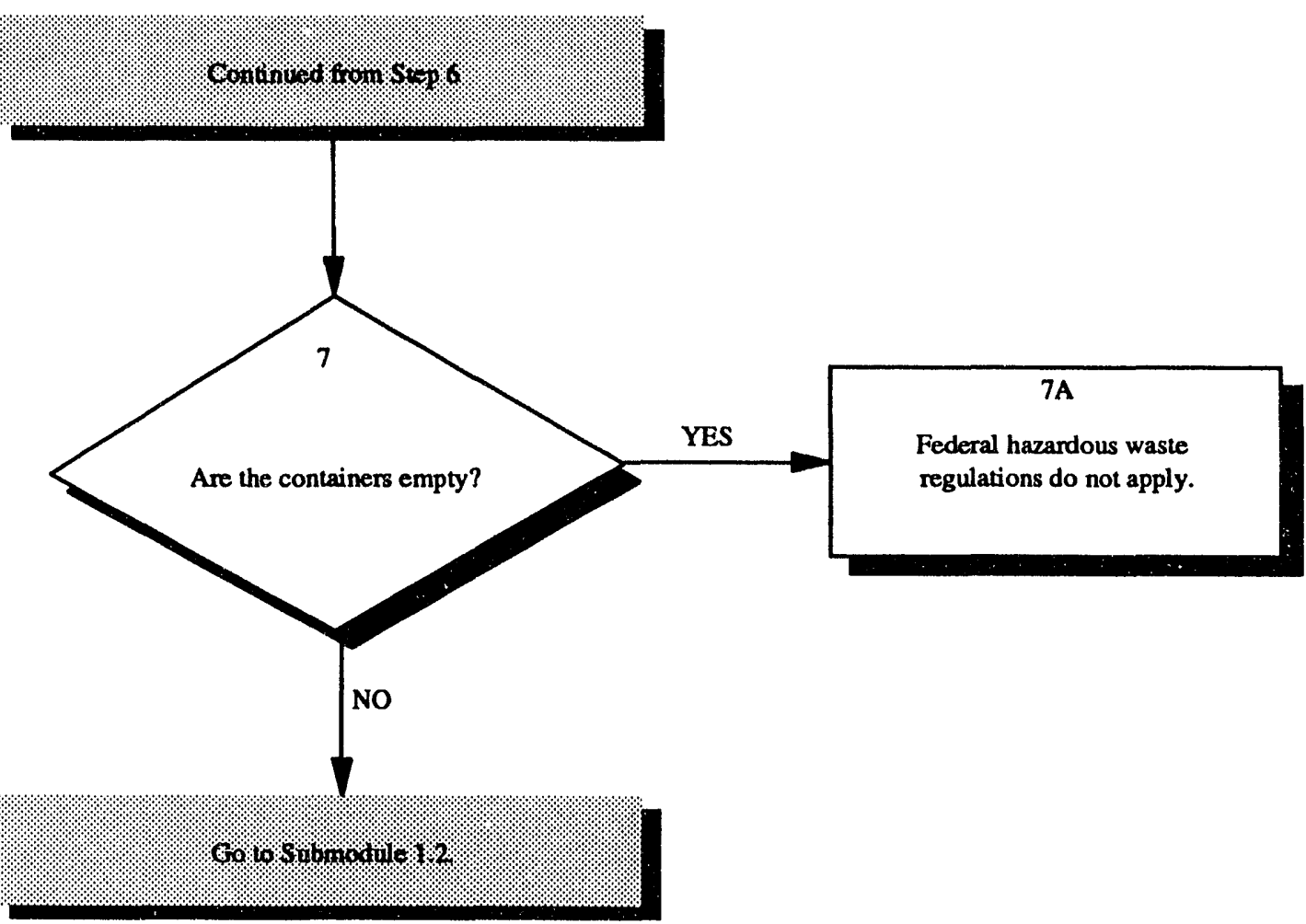


A container that has held hazardous or radioactive mixed waste is considered "empty" (40 CFR 261.7(b)(1)) if:

- all hazardous or radioactive mixed wastes have been removed that car be removed using practices commonly employed and no more than 2.5 centimeters of residue remain on the bottom of the container or inner liner; or

- residual hazardous or radioactive mixed waste comprises:

-- $\quad$ no more than 3 percent, by weight, of the total capacity of the container or inner liner if the container is less than or equal to 110 gallons or -- $\quad$ no more than 0.3 percent, by weight, if the container is greater than 110 gallons.

A container that has held a hazardous waste that is a compressed gas is empty when the pressure in the container approaches atmospheric pressure (40 CFR 261.7(b)(1)(iii)(B)(2)).

A container or inner liner removed from a container that has held an acute hazardous waste (as listed in $261.31,261.32$, or $261.33(e)$ ) is empty if:

- the container or inner liner has been triple rinsed using a solvent capable of removing the commercial chemical product or manufacturing chemical intermediate;

- the container or inner liner has been cleaned by another method that has been shown in the scientific literature, or by tests conducted by the generator, to achieve equivalent removal; or

- the inner liner that prevented contact of the commercial chemical product or manufacturing chemical intermediate with the container has been removed.

Step 7A If the container is empty, Federal hazardous waste regulations do not apply. Note that the residue in a non-empty container (which held a commercial chemical product or manufacturing chemical intermediate) may still be exempt from hazardous waste regulation if the residue is being beneficially used or reused; legitimately recycled or reclaimed; or accumulated for use, re-use, recycling, or reclamation. For example, the residue would not be considered a hazardous waste if it remains in the container and the container is re-used to store the same commercial chemical product or manufacturing chemical intermediate it previously held. (See Definitions of Solid and Hazardous Wastes, DOE/EH-0273, U.S. Department of Energy, Office of Environmental Guidance, RCRA/CERCLA Division, Graphic Guidance Document, DOE/EH-0273, August 1992, and Requirements for the Recycling of Hazardous Wastes, U.S. Department of Energy, Office of Environmental Guidance, RCRA/CERCLA Division, RCRA Information Brief, EH-231-001/0990, September 1990, for additional information.) Also note that EPA has developed a number of initiatives that may affect the definitions of solid and hazardous waste and the regulation of hazardous waste recycling. 


\section{Module 1: Flowchart}

SUBMODULE 1.2: WHAT REQUIREMENTS APPLY TO RCRA CONTAINER STORAGE AREAS?

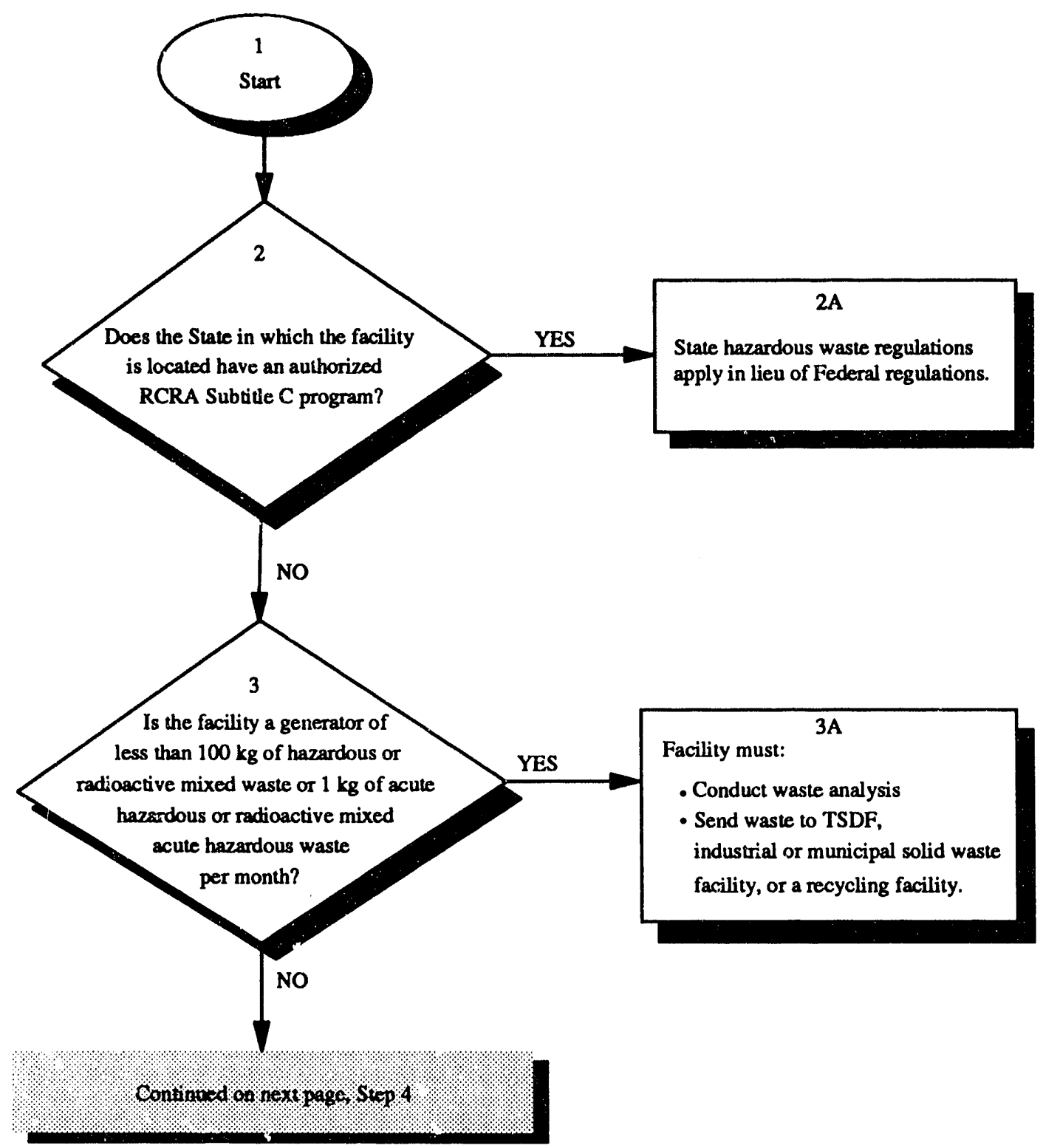




\section{SUBMODULE 1.2: WHAT REQUIREMENTS APPLY TO RCRA CONTAINER STORAGE AREAS?}

Step 1

Step 2

Step 2A

Step 3

Step 3A

Module 1
Start.

DOE container storage areas operating in States without approved RCRA programs should follow all of the applicable treatment, storage, and disposal requirements detailed in this guidance. Note that States may not be authorized for every aspect of RCRA (e.g., corrective action, radioactive mixed waste, etc.). The authorization status of a State may be ascertained by contacting the appropriate EPA Regional Office.

DOE container storage areas in States with authorized RCRA hazardous waste programs must meet the State's requirements for treatment, storage, and disposal facilities in lieu of Federal requirements. Authorized States must have programs that are at least as stringent as the Federal regulations. However, States are not precluded from adopting or enforcing requirements for TSDFs that are more stringent or more extensive than the Federal requirements. Facilities in States with approved programs may use this document as general guidance; however, line management and environmental oversight personnel should consult State regulations for precise information on State aazardous waste container requirements.

If a State has RCRA base program authorization, but is not authorized for radioactive mixed waste, the hazardous component of such waste is not regulated under RCRA (51 FR 24504). However, the hazardous component could still be subject to State requirements, if any separate requirements exist. In addition, after September 25, 1990 , radioactive mixed waste that exhibits the toxicity characteristic (TC) is regulated under RCRA, regardless of the authorization status of the State. The TC regulations were promulgated in response to HSWA requirements. HSWA also specified that EPA Regions must implement all HSWA requirements in States that are not authorized. Regardless of any considerations of State authorization, proper handling of containers of radioactive mixed waste in States without mixed waste authorization is good management practice.

DOE facilities that generate less than 100 kilograms of hazardous waste or radioactive mixed waste or 1 kilogram of acute hazardous waste or radioactive mixed waste in a calendar month are considered conditionally exempt small quantity generators and are subject to a minimum number of generator requirements (40 CFR 264.5(b)). However, managing all hazardous waste or radioactive mixed waste in accordance with substantive RCRA requirements, regardless of whether facility threshold quantities have been exceeded, is good management practice.

Conditionally exempt small quantity generators must meet the hazardous waste determination requirements of 40 CFR 262.11, and must dispose of the waste on-site, or off-site at: a permitted or interim status TSDF; a State permitted, licensed, or registered municipal or industrial solid waste facility; or a recycling facility (40 CFR 261.5(f)(3)). If more than 1,000 kilograms of hazardous waste, or 1 kilogram of acute hazardous waste or 100 kilograms of any residue resulting from the cleanup of an acute hazardous waste are accumulated on-site, waste management personnel must comply with the provisions of Part 262 for generators of between $100 \mathrm{~kg}$ and $1000 \mathrm{~kg}$ of hazardous waste, requirements in 40 CFR Parts 263 - 266, land disposal restrictions in 40 CFR Part 268, and notification and permitting requirements (40 CFR 261.5(e)). 


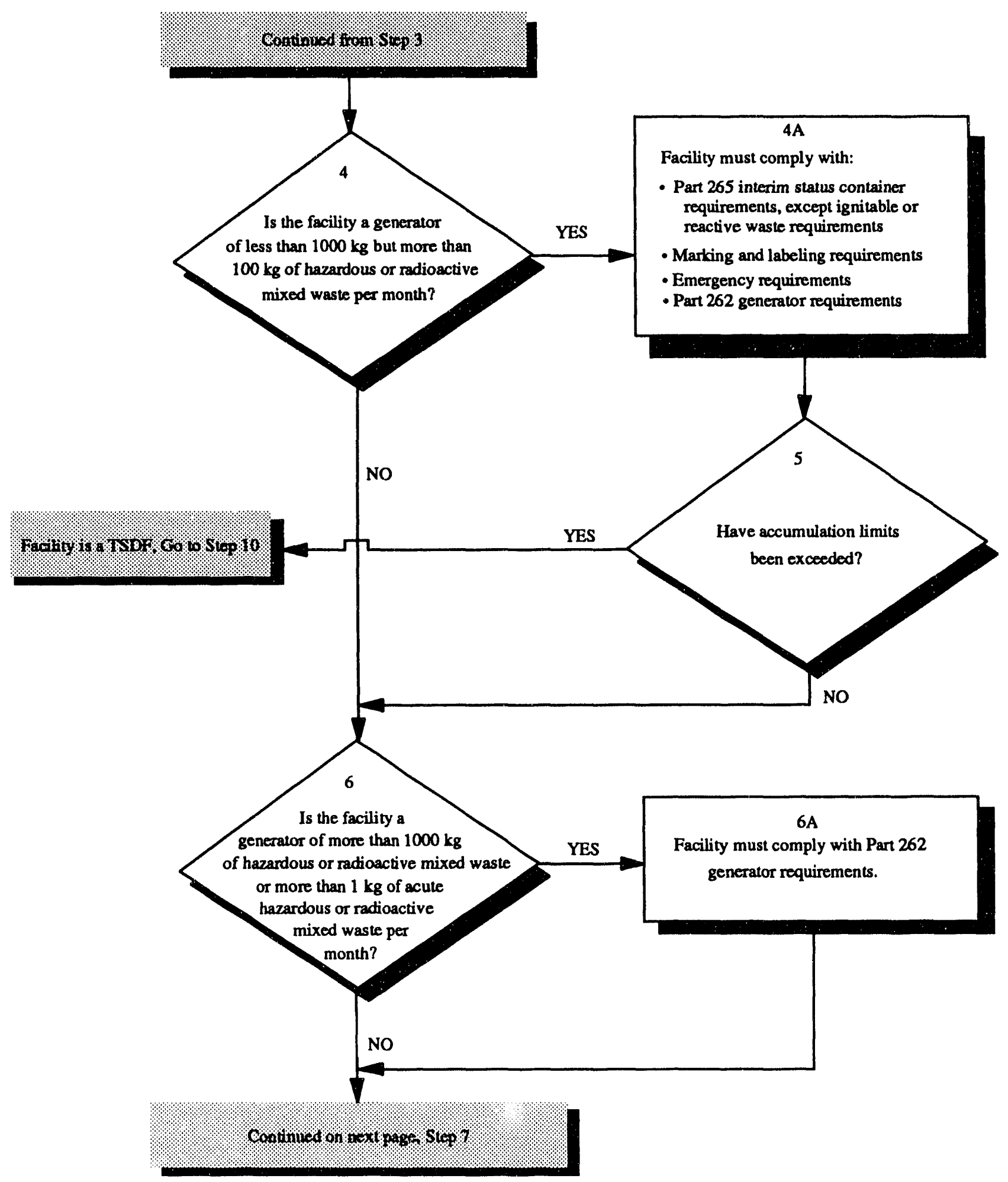


If a facility generates more than 100 kilograms but less than 1,000 kilograms of hazardous waste in a calendar month, it is considered a small quantity generator and may, without obtaining a RCRA permit or interim status, (1) accumulate hazardous waste on-site in containers for 180 days or less, or (2) for 270 days if the waste must be transported a distance exceeding 200 miles. The total quantity of waste accumulated must not exceed 6,000 kilograms (40 CFR 262.34(d)). DOE may request an extension of up to 30 days on these periods if unforeseen, temporary, or uncontrollable circumstances arise (40 CFR 262.34(f)).

Step 4A Waste management personnel at these facilities (40 CFR 262.34(d)) must ensure that:

- the storage area meets the interim status container management requirements of Subpart I of Part 265 (except for special requirements for ignitable or reactive wastes (40 CFR 265.176));

- $\quad$ each container is clearly marked with the words "hazardous waste," the container is labeled, and the date when accumulation began is clearly marked and visible;

- an emergency coordinator is designated at the facility and emergency information is posted next to the phone(s); and

- all waste management employees are familiar with waste handling and emergency procedures and respond as prescribed to all emergency situations.

Step 5

If a facility (1) accumulates hazardous waste for more than 180 days, or (2) stores hazardous wastes for over 270 days if the waste must be transported over a distance exceeding 200 miles, or (3) stores more than 6,000 kilograms of waste, it is considered a storage facility. As a storage facility, the facility is subject to all of the technical requirements of 40 CFR Parts 264 and 265, Subpart I, and the permit requirements of 40 CFR Part 270.

Step 6 Generators accumulating in a month more than 1,000 kilograms of hazardous waste or radioactive mixed waste or 1 kilogram of acutely hazardous waste or radioactive mixed waste are defined as large-quantity generators.

Step 6A The facility must comply with all Part 262 generator requirements. 


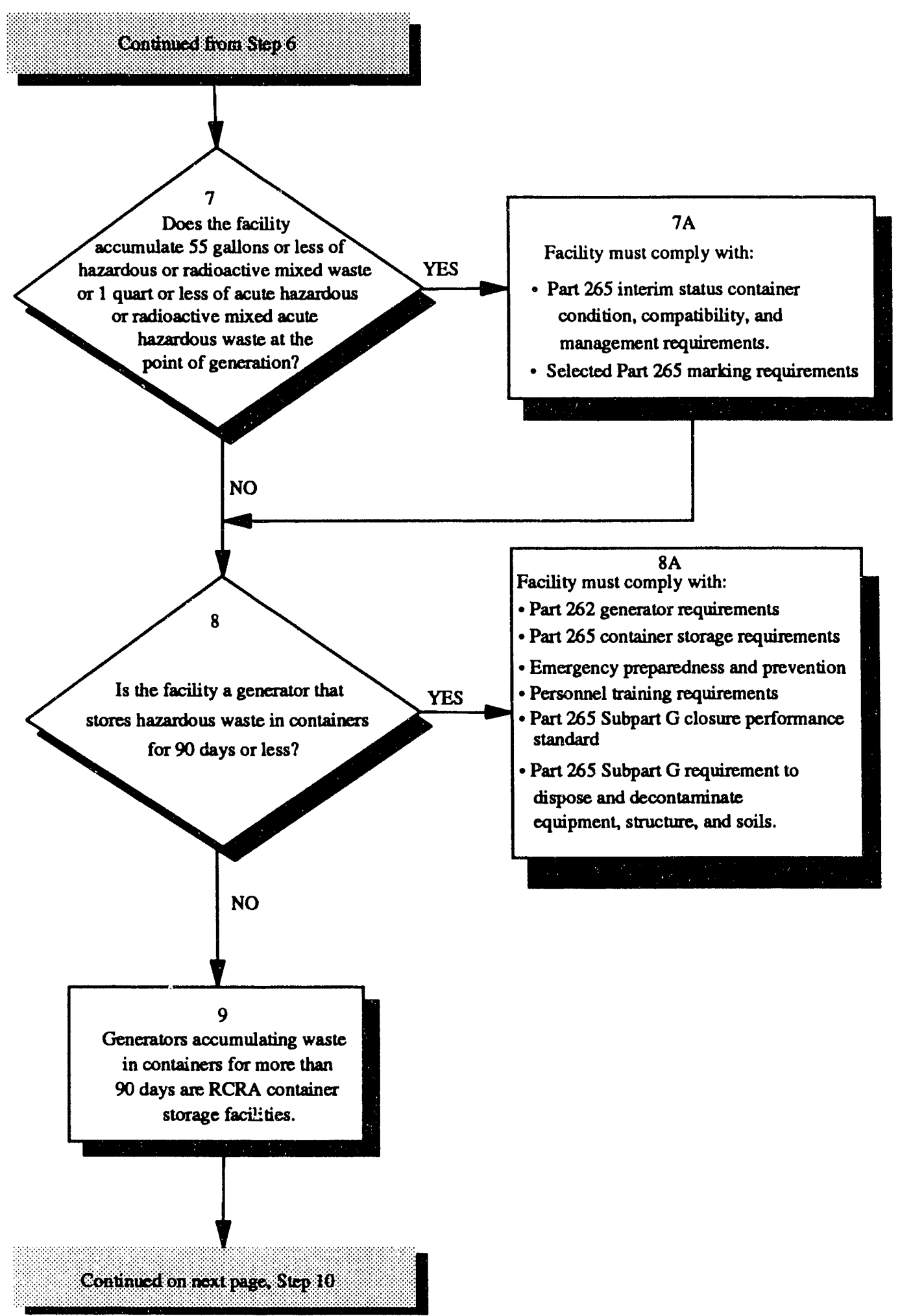


DOE facilities may accumulate up to 55 gallons of hazardous waste or radioactive mixed waste or one quart of acutely hazardous waste or radioactive mixed waste at or near the point of generation without a permit or interim status. An area used in this way is termed a satellite accumulation area. If a DOE facility exceeds the satellite accumulation area limits, it must, within three days, manage the excess accumulation in accordance with the 90-day storage requirements.

Step 7A Waste accumulated at a satellite accumulation area must be stored in containers that are properly marked, in good condition, and not reactive with the waste. These containers must be closed at all times, except when adding or removing waste, and they must not be opened in any way that would damage the container. Consult submodules $3.2,3.3$, and 3.6.

Step 8 Generators (excluding conditionally exempt small-quantity generators and 100 to 1,000 kilogram per month generators) that store hazardous waste or radioactive mixed wastes in containers for 90 days or less are subject to all generator requirements (40 CFR 262.34), but are not subject to all the permitting or interim status requirements. If a DOE facility accumulates hazardous waste for more than 90 days it is considered a storage facility and subject to all of the requirements of 40 CFR Parts 264 and 265 and the permit requirements of 40 CFR Part 270 . Waste management personnel may request an extension of up to 30 days on this 90 -day period if unforeseen, temporary, or uncontrollable circumstances arise.

Step 8A Generators must ensure that all containers are clearly marked and labeled and list the date when accumulation began. In addition, waste management personnel must be trained in accordance with 265.16 and also comply with the emergency preparedness and response requirements of Subparts $C$ and D of Part 265. These facilities must also comply with the interim status container storage area requirements of 40 CFR 265 Subpart I, as well as the closure performance standard of 265.111 and the decontamination or disposal procedures for equipment, structures, and soils of Subpart 265.114. (For more information, see OSHA Training Requirements for Hazardous Waste Operations, U.S. Department of Energy, Office of Environment, Safety, and Health, RCRA/CERCLA Division, Guidance Manual, DOE/EH-0227P, December 1991).

Step 9 A generator who accumulates hazardous wastes or radioactive mixed wastes for more than 90 days is an operator of a storage facility, and is therefore subject to the requirements of 40 CFR Parts 264 and 265 "Standards for Owners and Operators of Hazardous Waste Treatment, Storage, and Disposal Facilities" for permitted and interim status facilities respectively, and the permit requirements of 40 CFR Part 270 unless the generator has been granted an extension to the 90 -day period. Such extensions are granted by the EPA if hazardous wastes or radioactive mixed wastes must remain on-site for more than 90 days due to unforeseen, temporary, and uncontrollable circumstances. 


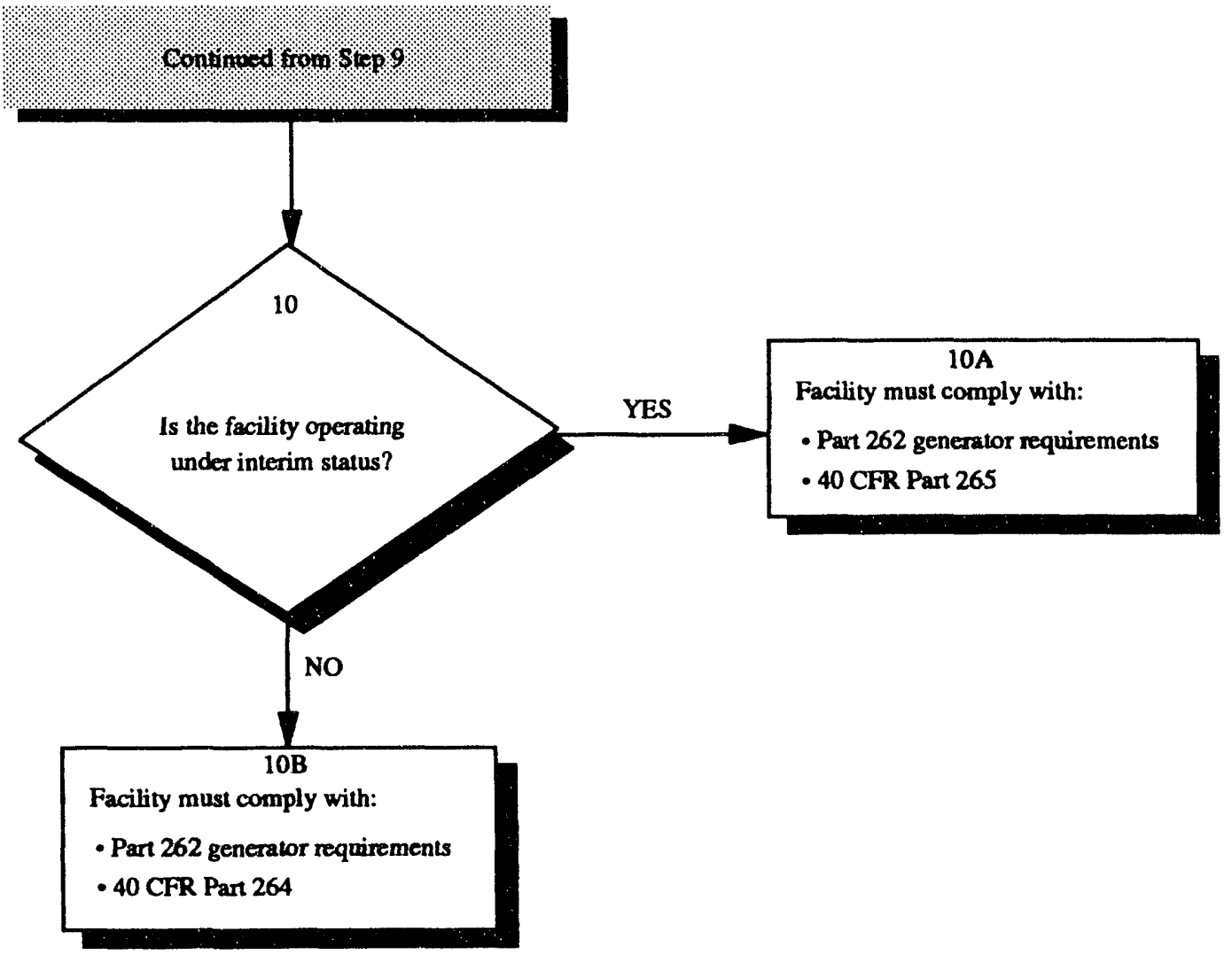


- must have been treating, storing, or disposing of the hazardous waste, commenced facility construction on or before November 19,1980, or be in existence on the effective date of statutory or regulatory amendments under the Act that rendered the facility subject to the requirement to have a RCRA permit;

- $\quad$ must comply with the RCRA Section 3010 notification requirements; and

- must apply for a permit under 40 CFR Part 270. The Part 265 interim status regulations must be met until a final administrative disposition of the permit application is made.

Step 10A Facilities that qualify for interim status must comply with the hazardous waste management requirements of $40 \mathrm{CFR}$ Part 265. DOE facilities that generate hazardous waste and treat, store, or dispose of hazardous waste on-site are subject to Part 262 generator requirements.

Step 10B Facilities that receive a permit, or are already operating under a permit, must comply with the requirements of Part 264. If the facility generates hazardous waste, waste management personnel must ensure it complies with generator requirements, as outlined in Step 10a. 


\section{REFERENCES FOR MODULE 1}

1) Definitions of Solid and Hazardous Wastes, U.S. Department of Energy, Office of Environmental Guidance, RCRA/CERCLA Division, Graphic Guidance Document DOE/EH-0273, August 1992.

2) Managing and Tracking Medical Wastes - A Guide to the Federal Program for Generators, U.S. Environmental Protection Agency, EPA 530-SW-89-021, September 1989.

3) Managing and Tracking Medical Wastes - A Guide to the Federal Program for Treatment, Destruction, and Disposal Facilities, U.S. Environmental Protection Agency, EPA 530-SW-89-023, September 1989.

4) Managing and Tracking Medical Wastes - A Guide to the Federal Program for Transporters, U.S. Environmental Protection Agency, EPA 530-SW-89-022, September 1989.

5) PCB Manifesting, Tracking, and Disposal Requirements, U.S. Department of Energy, Office of Environmental Guidance, RCRA/CERCLA Division, Information Brief, EH-231-001/1190, November 1990.

6) Hazardous and Radioactive Mixed Waste Programs, U.S. Department of Energy, DOE Order 5400.3, February 22, 1989.

7) Radioactive Waste Management, U.S. Department of Energy, DOE Order 5820.2A, September 26, 1989.

8) Radiation Protection for Occupational Workers, U.S. Department of Energy, DOE Order 5480.11, July 20, 1989.

9) Radiation Protection of the Public and the Environment, U.S. Department of Energy, DOE Order 5400.5, February 8, 1990.

10) Requirements for the Recycling of Hazardous Wastes, U.S. Department of Energy, Office of Environmental Guidance, RCRA/CERCLA Division, Information Brief, EH-231-001/0990, September 1990.

11) OSHA Training Requirements for Hazardous Waste Operations, U.S. Department of Energy, Office of Environment, Safety, and Health, RCRA/CERCLA Division, Guidance Manual, DOE/EH-(227P, December 1991.

12) 40 CFR 260 Appendix I -- Overview of Subtitle C Regulations (i. c., Definitions of Solid and Hazardous Wastes). 


\section{REFERENCES FOR MODULE 1 (cont.)}

14) 40 CFR 261.7 -- Residues of hazardous waste in empty containers.

15) 40 CFR 261.33(c) -- Discarded commercial chemical products, offspecification species, container residues, and spill residues thereof.

16) 40 CFR 262.10 -- Purpose, scope, and applicability of generator requirements.

17) 40 CFR 262.34 -- Accumulation time.

18) 40 CFR 264.1 -- Purpose, scope, and applicability of TSDF requirements.

19) 40 CFR 264 and 265 Subpart I -- Use and management of containers. 
[This page intentionally blank] 


\section{MODULE 2}

\section{CONTAINER FACILITY DESIGN AND CONSTRUCTION}

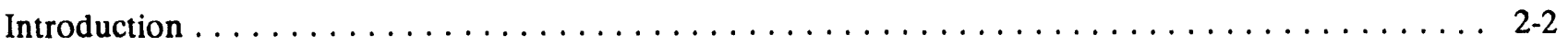

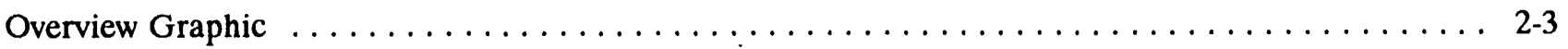

Submodule 2.1 - General Container Facility Design and Construction Standards . . . . . . . . . . . . . . . . . . . 2-4

Exhibit 2.1.1 - Sample Container Storage Area Configuration $\ldots \ldots \ldots \ldots \ldots \ldots \ldots \ldots \ldots$

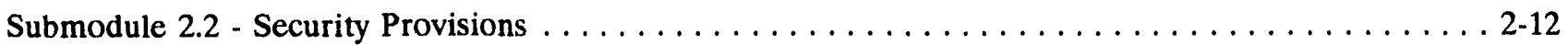

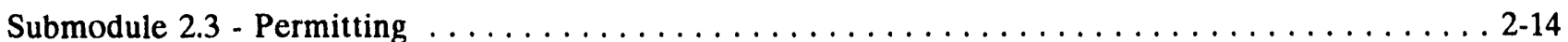




\section{Introduction to Module 2: Container Facility Design and Construction}

This module describes the RCRA requirements that apply primarily to the container storage area itself, rather than the hazardous or mixed waste, the containers, or facility operating procedures. Line management and environmental oversight personnel should use this module to:

- $\quad$ ensure compliance with container storage area standards such as design requirements, aisle spacing, containment system specifications, and location standards;

- devclop a system to maintain security at the container storage area and prevent unauthorized entry; and

- $\quad$ ensure compliance with RCRA permit application, modification, and reapplication procedures, as well as interim status standards if the container storage area has not yet received a permit.

The following flowchart and accompanying narrative discussion guides you step-by-step through the applicable requirements for container storage areas. 


\title{
OVERVIEW OF MODULE 2: CONTAINER FACILITY DESIGN AND CONSTRUCTION
}

\author{
SUBMODULES CONTAINING GUIDANCE
}

CRITICAL ISSUES

ON CRITICAL ISSUES

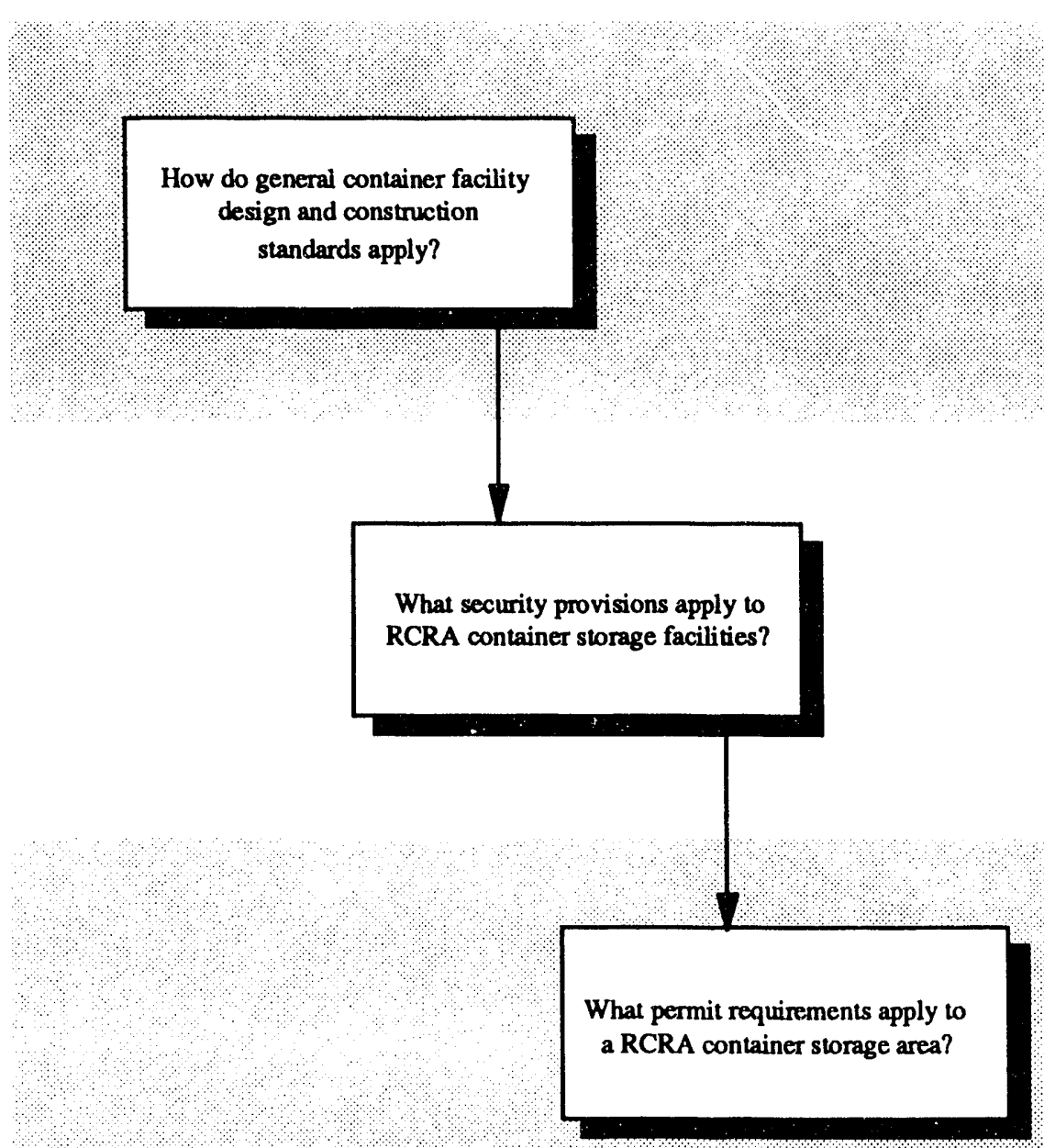

SUBMODULE 2.1

SUBMODULE 2.2

SUBMODULE 2,3 


\section{Module 2: Flowchart}

\section{SUBMODULE 2.1: GENERAL CONTAINER FACILITY DESIGN AND CONSTRUCTION STANDADRS}

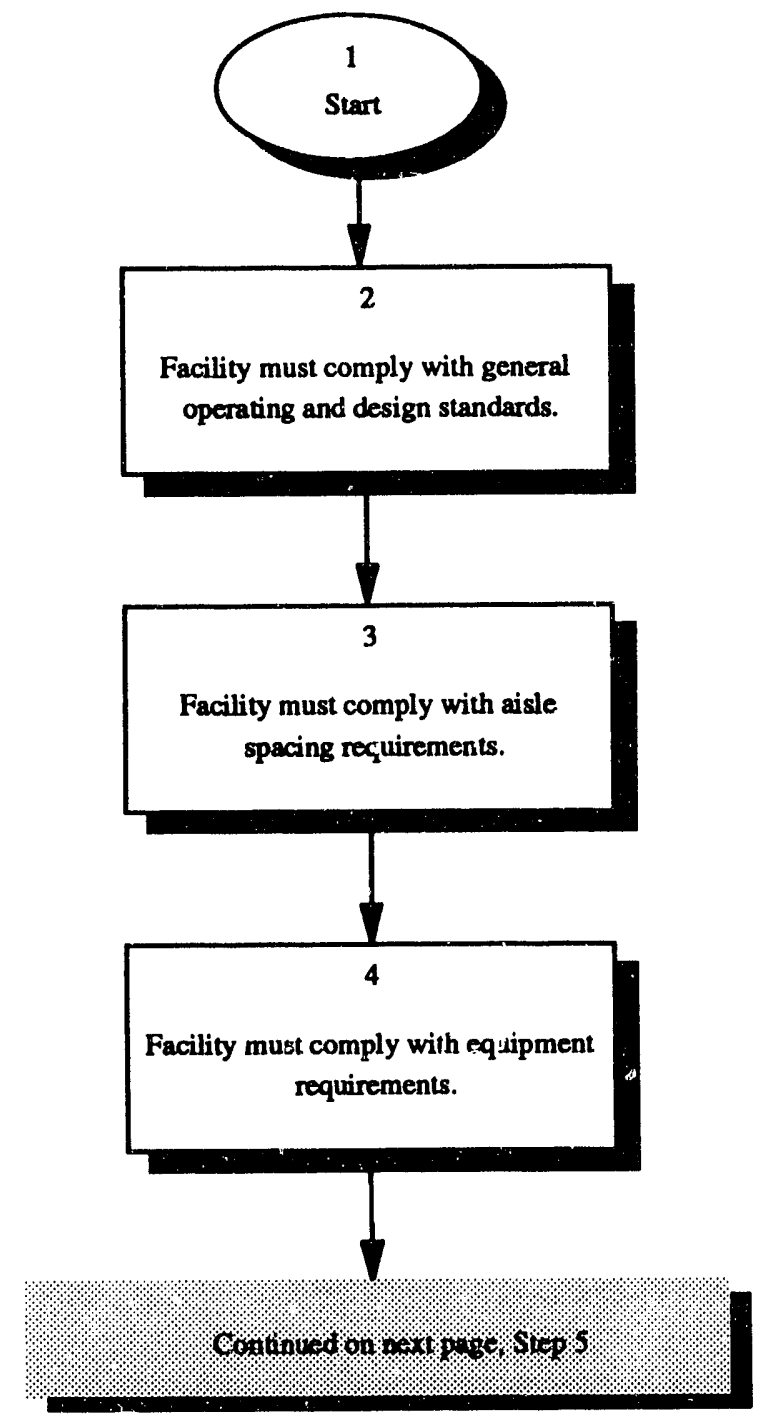

Note: Radiation Protection Standards under AEA may not allow cumpliance with normal RCRA aisle spacing requirements. 


\section{SUBMODULE 2.1: GENERAL CONTAINER FACILITY DESIGN AND CONSTRUCTION STANDARDS}

Step $1 \quad$ Start.

Step 2 Both permitted and interim status container storage areas are subject to the general design and operation standards located in 40 CFR Parts 264 and 265 Subpart B, respectively, and described in subsequent submodules of this guidance document (e.g., Submodule 4.2, "Security"; Submodule 3.4, "Inspections"; Submodule 3.2, "Compatibility").

Step 3 Waste management personnel at container storage areas must maintain sufficient aisle space to allow unobstructed movement of personnel and emergency equipment to any area of a facility, unless they can demonstrate that aisle space is not needed for these purposes (40 CFR 264.35). This demonstration must be included with Part B of the RCRA permit application. See Exhibit 2.1.1 at the end of this submodule for an example of container configurations. If such configurations are submitted with a Part B permit application, they should be clearly marked as "typical" or "example."

NOTE: For some of DOE's radioactive mixed waste streams, compliance with normal $R C R A$ aisle space requirements could result in radiological exposures 10 workers that exceed applicable occupational exposure standards found in DOE Order 5480.11. DOE often stores containers of mixed transuranic waste in configurations with less aisle space than required by RCRA for hazardous waste. Such "dense-pack" configurations reduce radiation exposures to workers and the environment by increasing the amount of shielding beyond that which would occur if the required aisle space were provided. This safer configuration ensures that worker exposures are below numerical occupational radiation exposure limits, but is a violation of normal RCRA requirements. In such cases, DOE operations offices should seek agreement with the EPA or authorized State on alternative approaches to this waste management activity that would ensure worker protection and protect human health and the environment (pursuant to RCRA Section 1006(a), which defers to the AEA in the event of inconsistent requirements). Such ari alternative could require DOE to store the waste in dense-pack configurations but to use robotics, c..meras, and release detection equipment, rather than workers, to ensure that leaks are detected and do not enter the environment. (See also Submodule 3.4, "Inspections.")

Step 4

All DOE container storage areas must be equipped with an internal communications or alarm system; an external communications system to summon emergency response teams; portable fire extinguishers, ïre control equipment, and decontamination equipment; and adequate water supplies for the equipment. All required emergency equipment must be tested and maintained as necessary to ensure proper operation in case of an emergency. Waste management personnel must have immediate access--directly or through another employee--to an internal alarm or emergency communication device whenever hazardous waste is being poured, mixed, spread, or otherwise handled. If only one employee is on the premises during a facility's operation, that person must have immedia a access to an external communication device to summon emergency assistance (40 CFR 264.32 264.35).

Waste management personnel may be exempt from one or more of these requirements if they can demonstrate that none of the hazards posed by waste handled at the facility require one or more of the types of equipment described in this paragraph. This demonstration must be included with Part B of the RCRA permit application. 


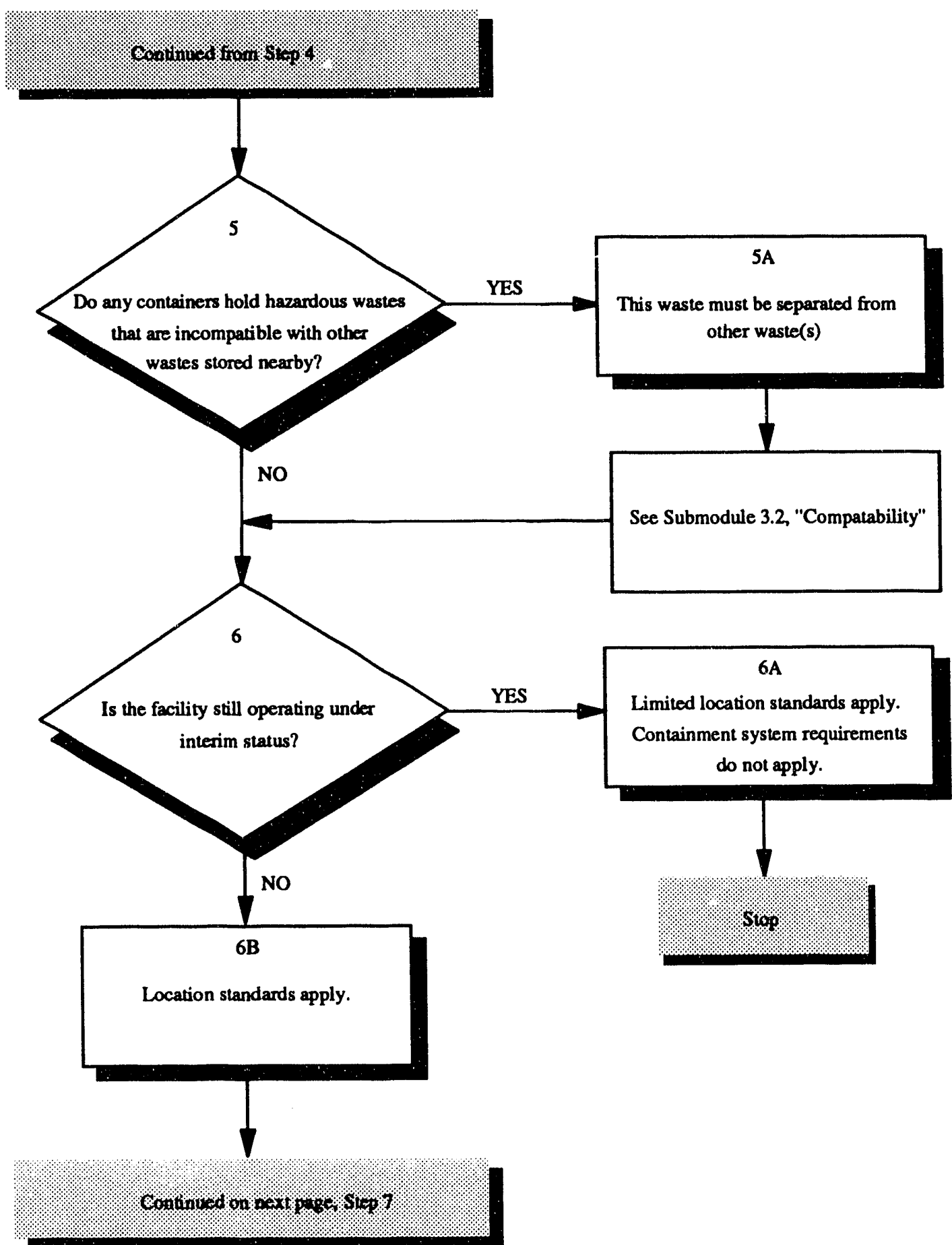


Waste management personnel must determine whether any of the containers in container storage areas are holding hazardous waste that is incompatible with other waste stored nearby (i.e., commingling with another waste under uncontrolled conditions might yield heat or pressure; fire or explosion; violent reaction; toxic dusts, mists, fumes, or gases; or flammable fumes or gases). Submodule 3.2, "Compatibility," will assist waste management personnel in determining the compatibility of wastes with one another.

Step 5A DOE container storage areas that do contain hazardous waste that is incompatible with other waste stored nearby must be separated from such waste by a wall, dike, berm, or other device.

Step 6

Waste management personnel must determine whether their facility has interim status, as discussed in Submodule 2.3, "Permitting," and Module 1, "Applicability."

Step 6A Interim status container storage areas may not be located in a salt dome, salt bed formation, or underground mine or cave, except for DOE's Waste Isolation Pilot Project (WIPP) in New Mexico (40 CFR 265.18). Permitted facilities must comply with more extensive RCRA location standards and consider siting requirements in other Federal laws (see Step 6B below). In addition, there are no specific containment system requirements (e.g., construction on impervious base, run-on control systems, dikes, or spill collection systems as in 40 CFR 264.175) for interim status container storage areas, except for containers holding hazardous wastes that are incompatible with other waste stored nearby, as described in Step 5.

Step 6B Permitted facilities must comply with RCRA location standards and consider the siting requirements in the following Federal laws: the Wild and Scenic Rivers Act (16 U.S.C. 1273 et seq.); the National Historic Preservation Act (16 U.S.C. 470 et seq.); the Endangered Species Act (16 U.S.C. 1531 et seq.); the Coastal Zone Management Act (16 U.S.C. 1451 et seq.); the Fish and Wildlife Coordination Act (16 U.S.C. 661 et seq.); and Executive Orders. $40 \mathrm{CFR} 270.3$ lists the other Federal laws that may apply to the siting of RCRA facilities.

Permitted container storage areas must comply with the RCRA location standards of 40 CFR 264.18 relating to seismic zones and floodplains. The seismic zone standards stipulate that a new container storage area, or any portion thereof, must not be located within 61 meters (200 feet) of a fault that has had displacement in Holocene time.

To streamline the process of determining whether a facility is potentially restricted from a given area, EPA developed a list of political jurisdictions that have faults with Holocene epoch displacement. These jurisdictions are listed in Appendix VI of 40 CFR Part 264. If a DOE container storage area is to be located within one of the listed jurisdictions, it must be verified that the facility will not violate the location standards. A facility located in a jurisdiction that is not listed is assumed to be in compliance with the seismic zone location standards.

The floodplain location standards require that permitted container storage areas located in a 100-year floodplain must be designed, constructed, and operated to prevent a washout of any hazardous waste by a 100 -year flood unless waste management personnel can demonstrate in the RCRA Part B permit application that they have developed procedures for removing the waste before flood waters reach the facility. Removed waste must be sent to either a permitted or interim status hazardous waste facility. 


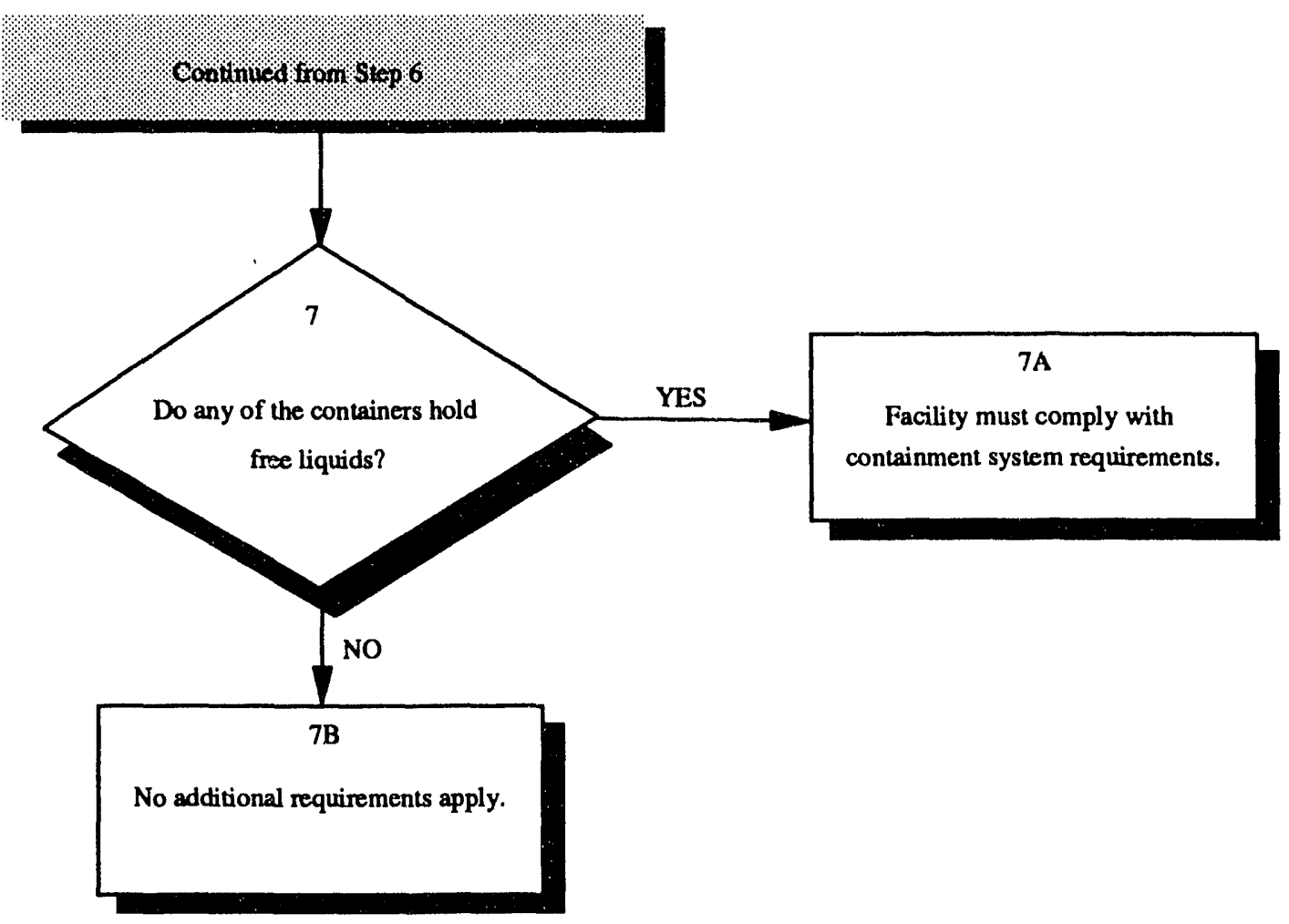


Waste management personnel must determine whether any of the containers in their storage area(s) contain any free liquids.

Step 7A Permitted container storage areas in which the containers hold free liquids must have containment systems with an impervious base that is sloped to prevent the accumulation of liquids, unless the containers are elevated or otherwise protected from liquid accumulation. The containment system must have enough capacity to hold 10 percent of the volume of the containers (not including containers holding non-free liquids) or the volume of the largest container, whichever is greater (40 CFR 264.175). In addition, waste management personnel must prevent run-on from entering the containment system, unless the collection system has sufficient excess capacity, in addition to that required above, to contain run-on. Spilled or leaked waste and accumulated precipitation must be removed to prevent overflow of the collection system.

If the collected material is defined as a hazardous waste under 40 CFR Part 261, it must be managed as a hazardous waste in accordance with Parts 262-268. If the collected material is released through a point-source discharge to waters of the United States, it is subject to the requirements of Section 402 of the Clean Water Act, as amended.

Step 7B Container storage areas at DOE facilities exclusively holding wastes that do not contain any free liquids do not need a containment system, provided that the storage area is sloped or otherwise designed to remove liquids; the containers are elevated or protected from potential liquid accumulation; and the containers do not contain FO20-FO23, FO26, or FO27 wastes.

\section{REFERENCES FOR SUBMODULE 2.1}

1) Guidance for Permit Writers: Facilities Storing Hazardous Waste in Containers, U.S. Environmental Protection Agency, Office of Solid Waste, 1982.

2) 40 CFR 264 Subpart B -- General facility standards.

3) 40 CFR 264 Subpart C -. Preparedness and prevention.

4) 40 CFR 264.175 -- Containment. 


\section{Exhibit 2.1.1 \\ Sample Container Storage Area Configuration}
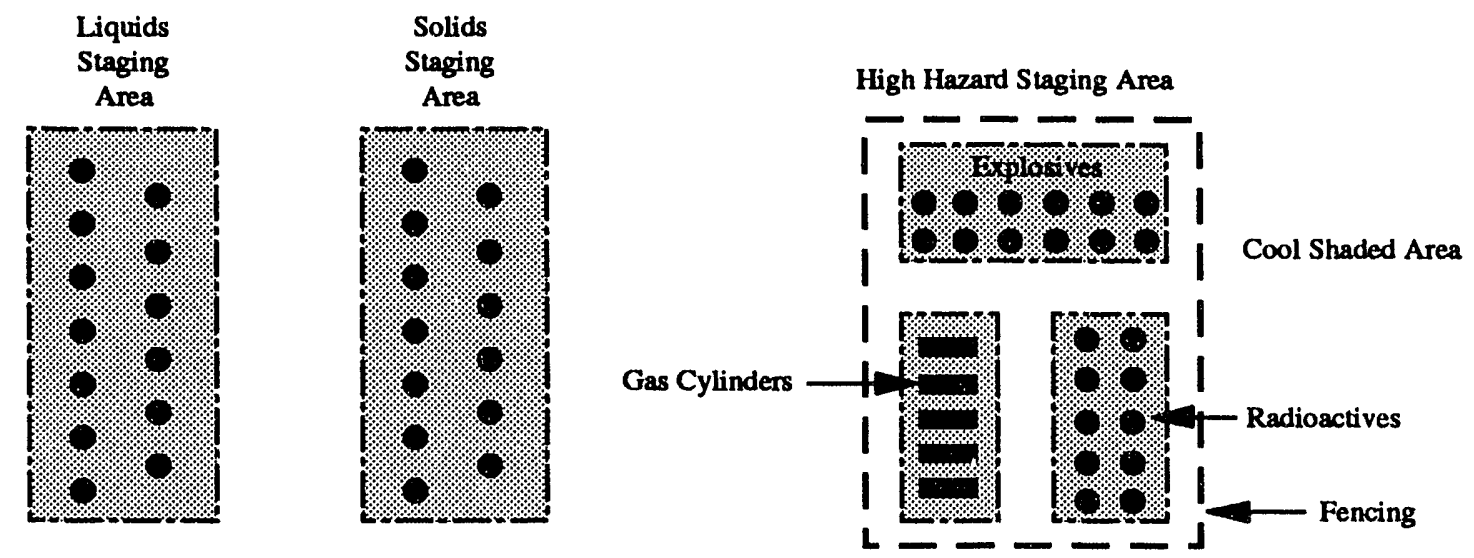

Aisle Spacing

Adequate to allow unobstructed movement of personnel and fire protection, spill control, and emergency equipment.

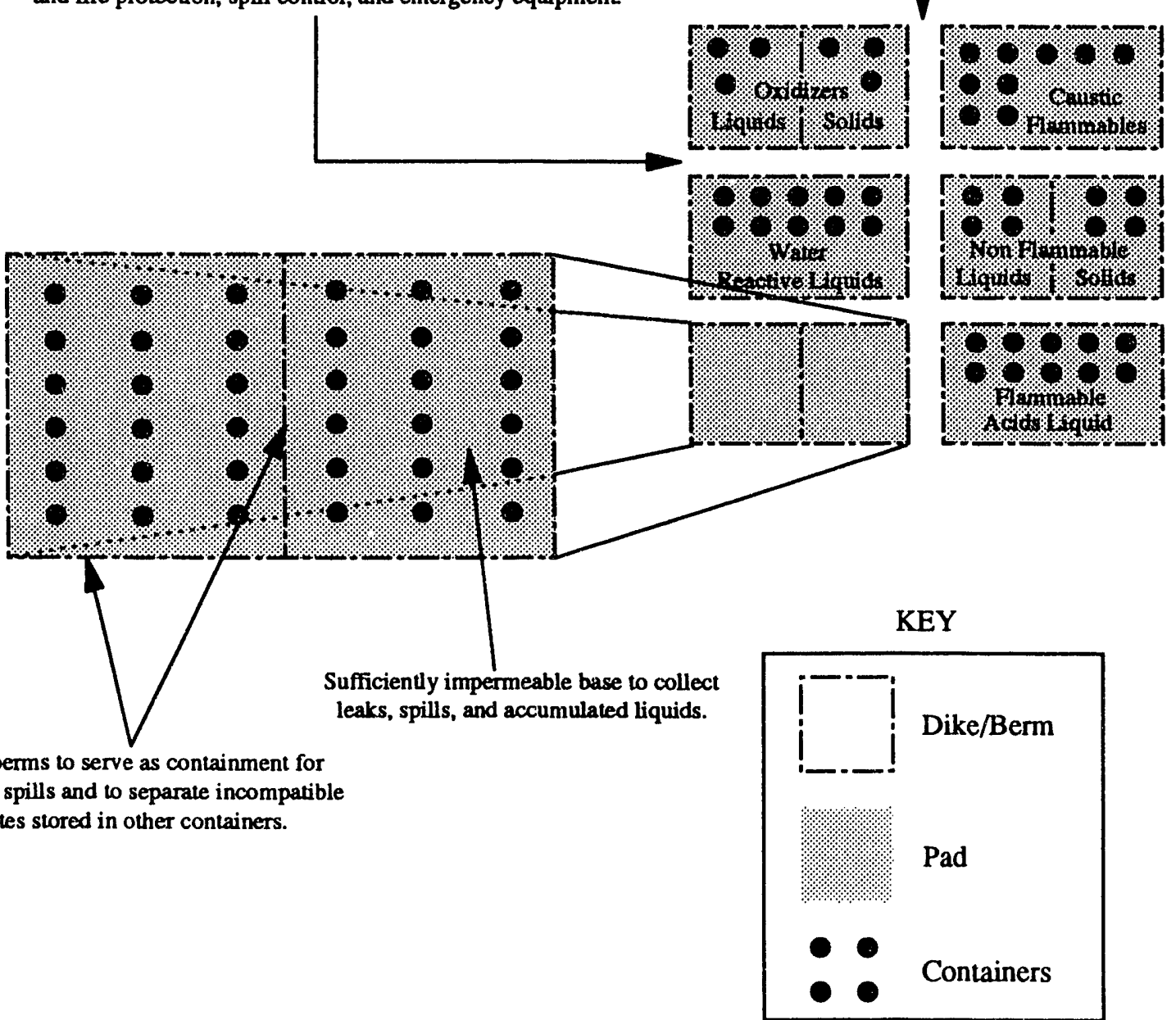


[This page intentionally blank] 


\section{Module 2: Flowchart}

\section{SUBMODULE 2.2: SECURITY PROVISIONS}

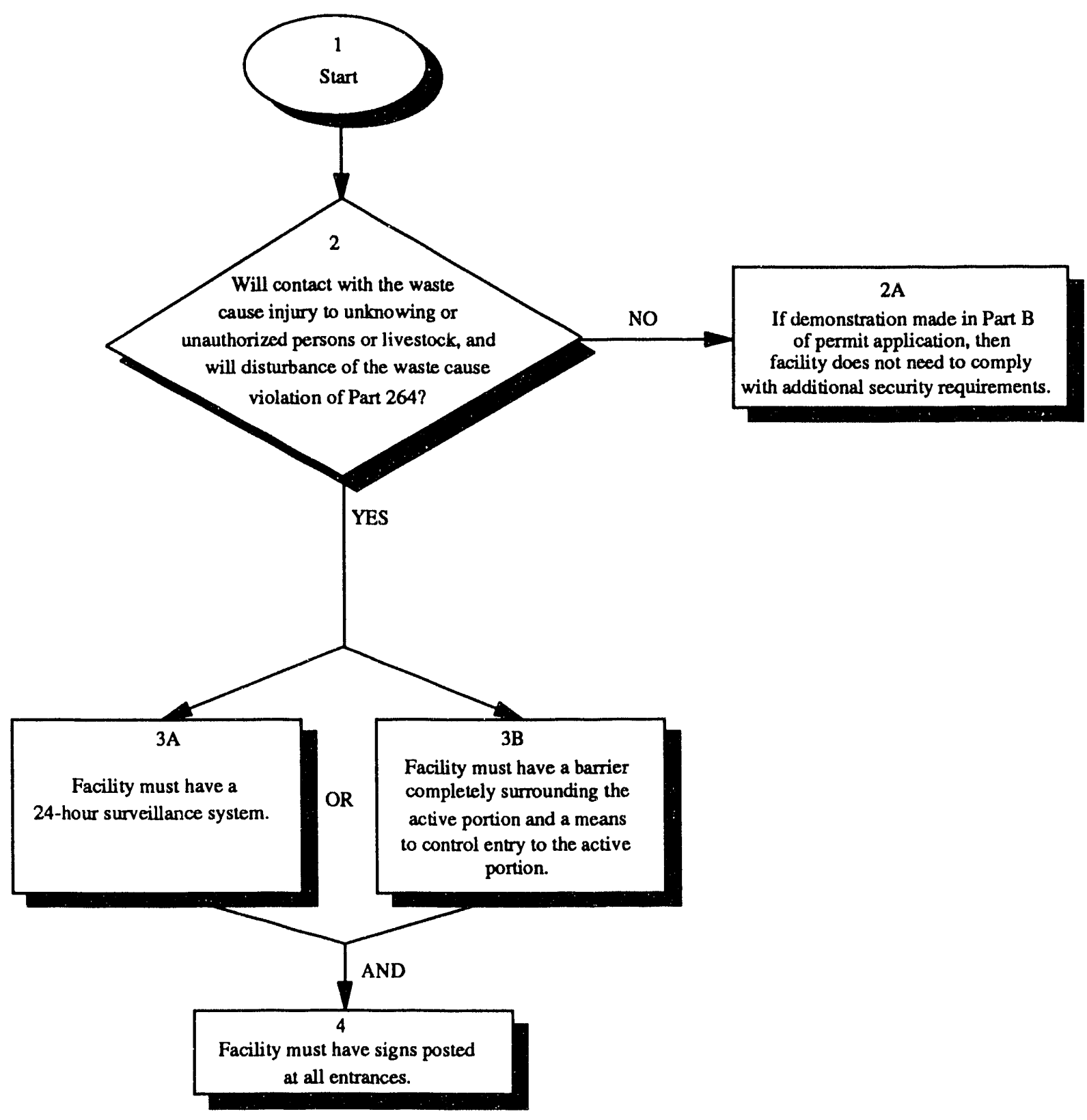




\section{SUBMODULE 2.2: $\quad$ SECURITY PROVISIONS}

Step $1 \quad$ Start.

Step 2 Waste management personnel must prevent unknowing entry, and minimize the possibility of unauthorized entry, of persons or livestock into container storage areas ${ }^{1}$, unless it can be demonstrated that (1) physical contact with the waste, structures, or equipment within the unit will not injure such persons or livestock which may enter; and (2) disturbance of the waste or equipment by unknowing or unauthorized persons or livestock will not cause a violation (e.g., mixing of incompatible waste) of the hazardous waste management requirements of 40 CFR Part 264.

Step 2A If waste management personnel demonstrate that the container storage area meets the above two requirements, then the unit need not comply with the remaining security requirements of 40 CFR 264.14. This demonstration must be made in Part B of the permit application.

Step 3A If waste management personnel do not demonstrate that the facility meets the two requirements in Step 2, then the container storage must have a 24 -hour surveillance system which continuously monitors and controls entry onto the active portions of the unit; or

Step 3B The container storage area must have an artificial (e.g., fence) or natural barrier which completely surrounds the unit and a means to control entry, at all times until closure, through the gates or other entrances to the unit.

Step 4 If waste management personnel do not demonstrate that the container storage area meets the two requirements in Step 2, then the facility must have signs with the legend "DangerUnauthorized Personnel Keep Out" posted at all entrances and in sufficient numbers to be seen from any approach to the active portion of the unit. The legend must be written in English and in any other language predominant in the area surrounding the unit, and must be legible from a distance of at least 25 feet.

\section{REFERENCES FOR SUBMODULE 2.2}

1)

40 CFR 264.14 -- Security.

\footnotetext{
${ }^{1}$ The security requirements for a container storage area are met if it is located within a facility that muets these requirements.
} 


\section{Module 2: Flowchart}

\section{SUBMODULE 2.3: PERMTTTING}

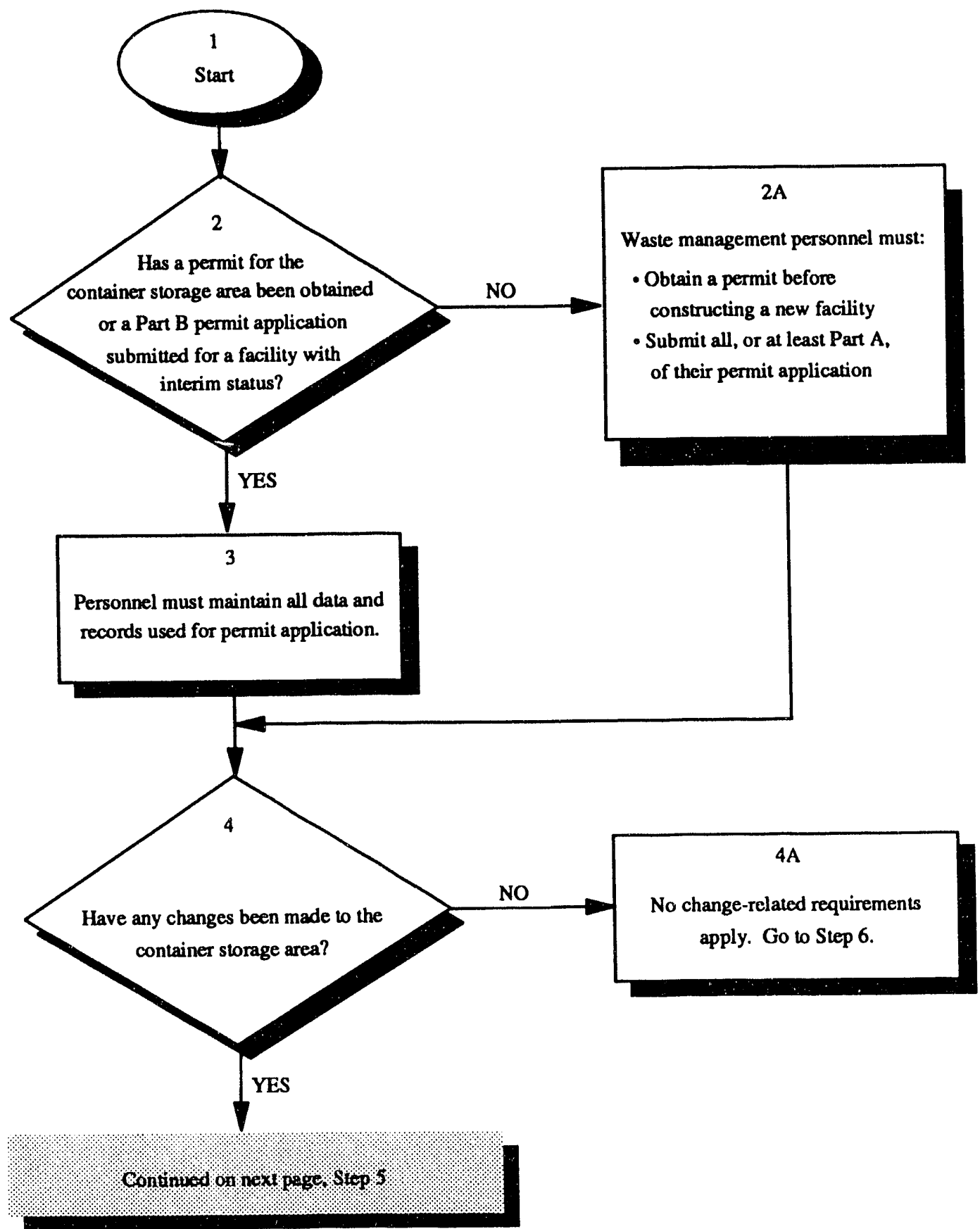




\section{SUBMODULE 2.3: $\quad$ PERMITTING}

Step 1

Step 2

Step 2A

Step 3

Step 4

Step 4A

Module 2
Start.

To operate a container storage area, waste management personnel must have either obtained a permit or submitted a permit application and complied with the interim status standards of 40 CFR Part 265. Permits identify the administrative and technical standards to which facilities must adhere. Permits can be issued by EPA or an authorized State. If the container storage area is the only hazardous waste management unit at a facility, the permit is issued for the container storage area alone; however, in most cases, waste management personnel will obtain a RCRA permit for a facility with many units, only some of which will be container storage areas.

Waste management personnel must submit Parts $A$ and $B$ of a permit application and receive a RCRA permit before constructing a new container storage area. 40 CFR Part 270 Subparts B-D detail the RCRA permitting requirements. Permit applications contain Parts A and B: Part A contains general information about a facility, such as the facility's name and location, while Part B includes a facility's description, operating procedures, and a closure plan, for example. Since there is no standard format for a Part B application, waste management personnel should consult the regulations (40 CFR Parts 264 and 270) and EPA guidance (see references at the end of this submodule).

In addition to the general Part $B$ information, the application must contain the following additional information: a description of the containment system (e.g., basic design parameters, construction materials); the maximum amounts and types of wastes that may be handled; a description of the containers to be used; sketches, drawings, or data exhibiting compliance with separation requirements for containers that will hold ignitable, incompatible, or reactive wastes; and a description of the procedures that will be used to handle such wastes. If the containers will hold wastes with no free liquids, the container storage area does not need a containment system, provided that line management personnel can demonstrate in the permit application through test procedures on the waste and design drawings and descriptions that the storage area complies with the design requirements of 40 CFR $264.175(\mathrm{c})$.

Existing container storage areas may operate under interim status as long as they have submitted Part $A$ of the permit application and comply with interim status requirements until a final permit decision is made. Part B permit applications must be submitted in accordance with deadlines established by regulation ( 40 CFR 270.73) or by the Regional Administrator or State Dir zctor. Waste management personnel may voluntarily submit a Part $B$ anytime before these deadlines pass.

Waste management personnel must keep records of all data used to complete permit applications and any supplemental information for at least three years from the date the application is signed. After a RCRA Permit is obtained, additional recordkeeping and reporting requirements (e.g., Biennial Report) apply to the facility. Consult Submodule 3.6, "Manifesting and Recordkeeping," for a discussion of these requirements.

Changes to the container storage area (e.g., increases in storage) or to its operating procedures (e.g., storage of new waste types), will require waste management personnel to either seek a permit modification or submit additional information to amend a previously submitted, yet unapproved, permit application. Consult Step 5A for more details.

If no changes have occurred to the containers, storage area, or operating procedures, waste management personnel need not submit materials or seek a permit modification. 


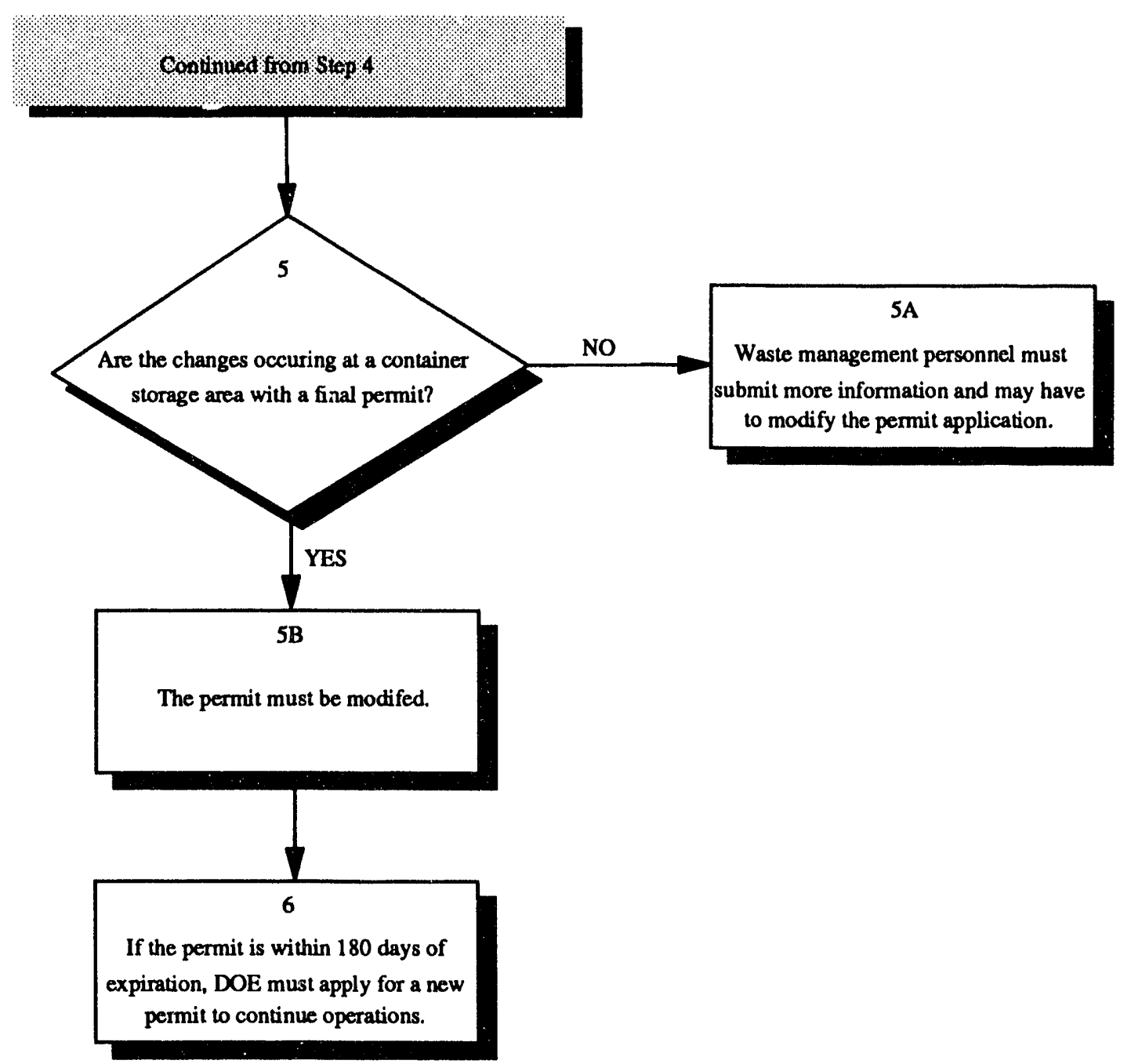


The appropriate response to changes at a container storage area will depend upon the permitting status of the facility. For a permitted facility, the types of changes requiring a permit modification are categorized in 40 CFR Part 270, Appendix I. Waste management personnel operating container storage areas in States authorized to issue permits should consult State requirements to determine if they are different (i.e., more stringent) from the Federal standards.

Step 5A The types of changes allowed at interim status facilities (subject to approval by the Regional Administrator or State Director) are specified in 40 CFR 270.72. These include storage of new wastes, increases in storage capacity, changes in operating procedures, changes in operational control of the facility, or changes made in accordance with a corrective action order or other Federal or State enforcement authority.

When these types of changes occur at an interim status facility, waste management personnel must provide additional information (as specified in 40 CFR 270.72) to the Regional Administrator or State Director. At the administrator's discretion, it may also be necessary to modify the permit application.

Step 5B Permit modifications may be initiated by the DOE facility or by the EPA Regional Administrator or State Director if they determine that sufficient grounds for a modification of a permit exist for a container storage area. When a permit is modified, only the conditions subject to the modification are reopened; however, if a permit is revoked and reissued, the entire permit is subject to revision.

The Regional Administrator or State Director may initiate a permit modification if the facility or its operations are altered significantly, new information about the facility becomes available, new statutory or regulatory requirements are enacted, unanticipated events occur (e.g., earthquake), or human health or the environment is otherwise threatened (40 CFR 270.41).

Appendix I of 40 CFR Part 270 lists three classes of changes to a facility in which a permittee may request a permit modification. In general, the higher the class, the more substantial the modification. For example, modification of a container storage unit without increasing the capacity of the unit is a Class 1 modification. Storage or treatment of different wastes in containers is also a Class 1 modification for most wastes. Modification or addition of container units resulting in up to a 25 -percent increase in the facility's container storage capacity is a Class 2 modification, while an increase of more than 25 percent would be a Class 3 modification.

Waste management personnel are required to undertake certain steps (e.g., notify the Regional Administrator, provide for public comment), specified in 40 CFR 270 Subpart D, that vary depending on the type of modification. For example, Class 2 and 3 modifications require announcement of a 60-day public comment period, while Class 1 modifications primarily require providing notice to the Regional Administrator or State Director and all other people on a facility's mailing list.

Step 6 If a container storage area is permitted and waste management personnel wish to continue operating the unit after the initial permit application expires, they must apply for a new permit at least 180 days before the expiration date of the current permit, unless granted an extension by the Regional Administrator or State Director. 


\section{REFERENCES FOR SUBMODULE 2.3}

1) Federal Environmental Permitting Handbook, U.S. Department of Energy, Office of Envirunmental Guidance, RCRA/CERCLA Division, OEG (RCRA)-003/0591, May 1991.

2) Nodel RCRA Permit for Hazardous Waste Management Facilities, U S. Environmental Protection Agency, PB-210 998, September 1988.

3) Federal Environmental Reporting Requirements Handbook, U.S. Department of Energy, RCRA/CERCLA Division, Office of Environmental Guidance, EGD(CERCLA)-001/0590, May 1990.

4) $\quad 40 \mathrm{CFR} 2 \% 0.10$ - General permit application requirements.

5) 40 CFR 270.11 - Signatories to permit applications and repe rts.

6) 40 CFR 270.12 - Conficentiality of information.

7) $\quad 40$ CFR 270.13 -- Contents of Part A permit application.

8) 40 CFR 270.14 - Crintents of Part B permit application: General requirements.

9) 40 CFR 270.15 - Specific Part B permit application information requirements for containers.

10) 40 CFR 270 Subpart D -. Changes to permit. 


\section{MODULE 3}

\section{MANAGEMENT OF CONTAINERS}

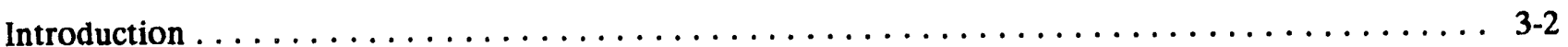

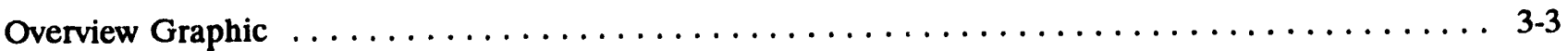

Submodule 3.1 - Waste Analysis $\ldots \ldots \ldots \ldots \ldots \ldots \ldots \ldots \ldots \ldots \ldots \ldots \ldots \ldots \ldots \ldots \ldots \ldots$

Submodule 3.2 - Compatibility $\ldots \ldots \ldots \ldots \ldots \ldots \ldots \ldots \ldots \ldots \ldots \ldots \ldots \ldots \ldots \ldots \ldots \ldots \ldots$

Subrnodule 3.3 - General Container Management Practices $\ldots \ldots \ldots \ldots \ldots \ldots \ldots \ldots \ldots \ldots$ 3-12

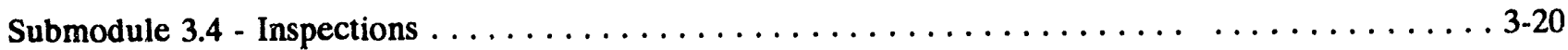

Exhibit 3.4.1 - Inspection Checklist for RCRA Container

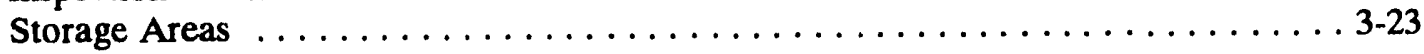

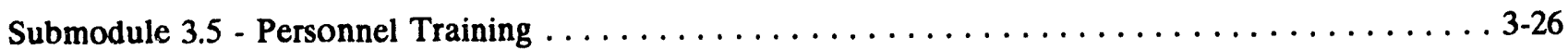

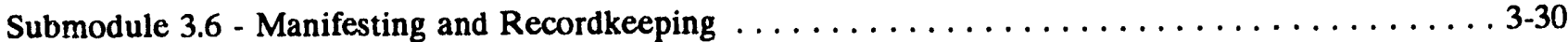

Exhibit 3.6.1 - Uniform Hazardous Waste Manifest . . . . . . . . . . . . . . . . 3 38

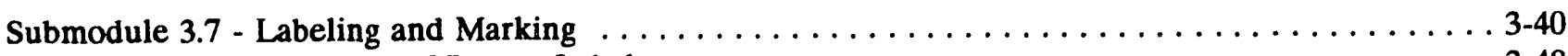

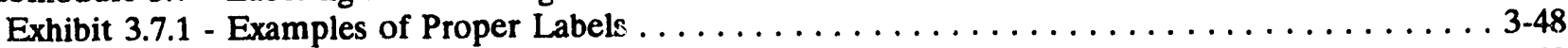

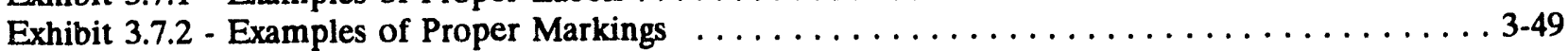

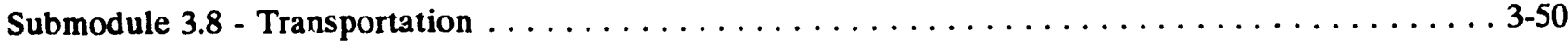

Module 3 


\section{Introduction to Module 3:}

This module describes the diverse requirements that apply to the management of containers at a container storage area. Waste management and environmental oversight personnel should use this module to:

- determine when and what waste analysis requirements apply to container storage areas and identify technical guidance manuals to assist waste management personnel in conducting such analyses;

- $\quad$ ensure that hazardous and radioactive mixed wastes stored in containers are compatible with other wastes and with the containers themselves;

- identify proper procedures for handling, moving, opening, or otherwise managing the containers in such a way as to comply with RCRA and other related requirements and ensure that waste management personnel are protected from any hazards associated with handling the containers;

- $\quad$ properly inspect containers and the container storage area;

- $\quad$ establish an acceptable personnel training program;

- $\quad$ comply with the RCRA manifesting requirements regardless of whether the container storage area is shipping or receiving wastes;

- $\quad$ comply with accumulation and pre-transport labeling and marking requirements; and

- $\quad$ identify the RCRA and DOT transportation requirements applicable to container storage areas and ensure that hazardous and radioactive mixed wastes are properly documented, marked, labeled, loaded, secured, and transported.

The following flowchart and accompanying narrative discussion guides you step-by-step through the applicable requirements for container storage areas. 


\section{OVERVIEW OF MODULE 3: MANAGEMENT OF CONTAINERS}

CRITICAL ISSUES

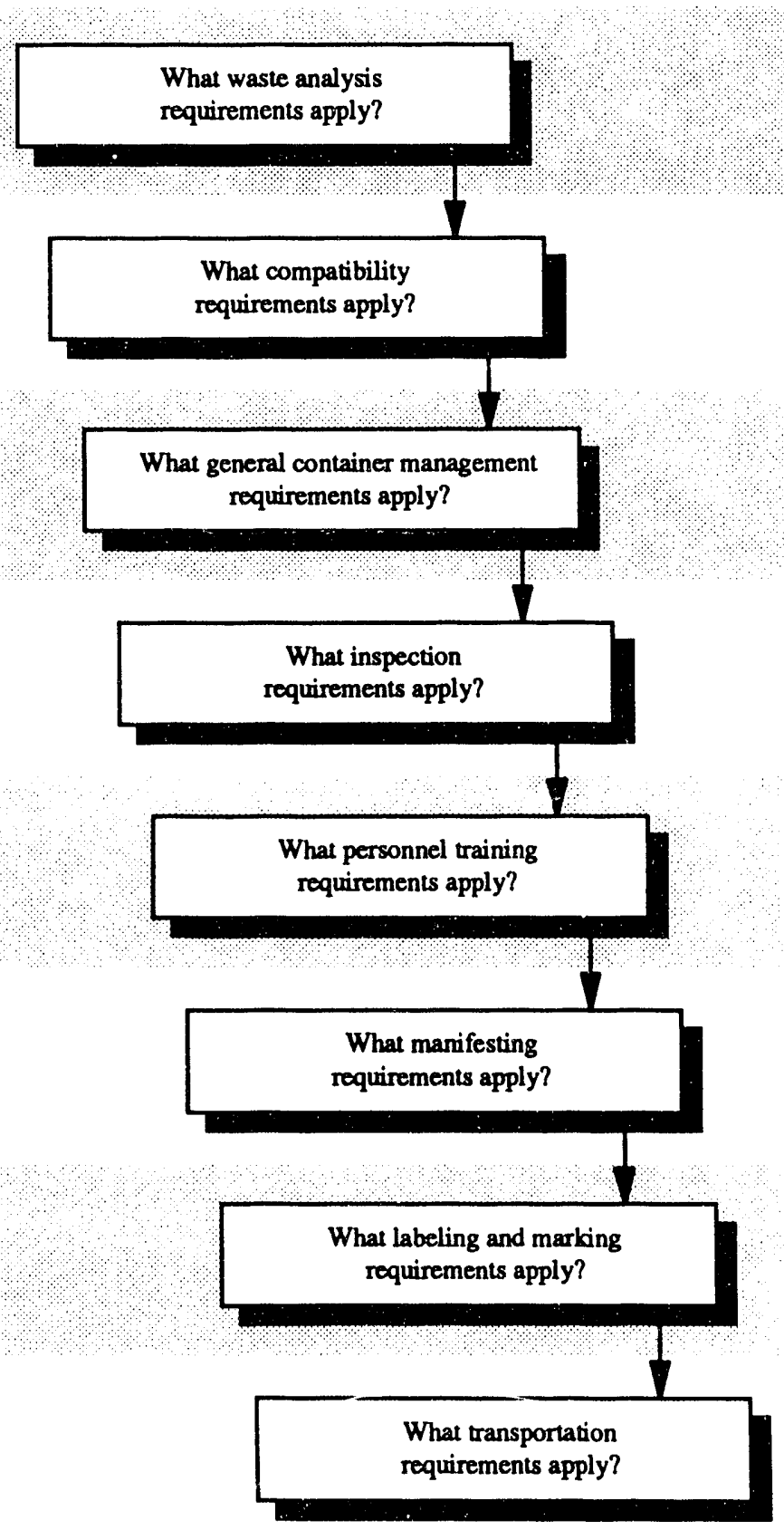

SUBMODULES CONTAINING GUIDANCE

ON CRITICAL ISSUES

SUBMODULE 3.1

SUBMODULE 3.2

SUBMODULE 3.3

SUBMODULE 3.4

SUBMODULE 3.5

SUBMODULE 3.6

SUBMODULE 3.7

SUBMODULE 3.8 


\section{Module 3: Flowchart}

\section{SUBMODULE 3.1: WASTE ANALYSIS}

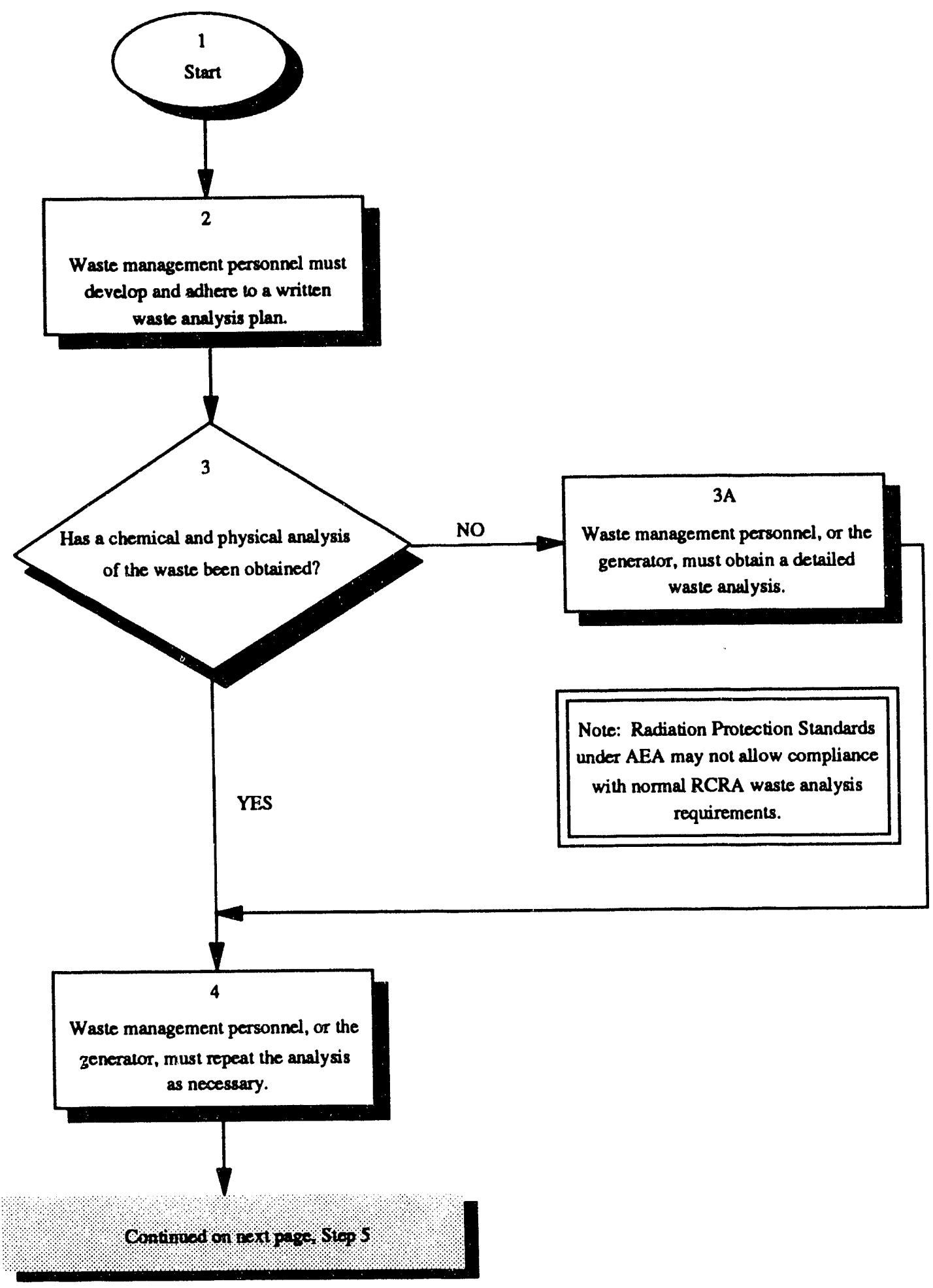

Note: Radiation Protection Standards under AEA may not allow compliance with normal RCRA waste analysis requirements. 
SUBMODULE 3.1 WASTE ANALYSIS

Step 1

Step 2

Step 3

Step 3A

Step 4

Start.

Waste management personnel must develop and follow a written waste analysis plan. (Consult Preparation of RCRA Waste Analysis Plans (Interim Guidance), DOE/EH-0306, March 1993). The plan must be kept at the facility and must specify the parameters for which each hazardous waste will be analyzed, the test methods and sampling methods to be used, and the frequency for conducting analyses (40 CFR 264.13 and 265.13). The waste analysis plan must specify procedures to identify potentially ignitable, reactive, or incompatible wastes (see Submodule 3.2, "Compatibility," for a discussion of compatibility requirements at container storage areas). Specifically, the plan must include procedures for determining the following: the compatibility of a waste to a container of a waste to other wastes stored nearby and of a waste to wastes previously held in reused containers. The plan must also establish procedures for analyzing ignitable/reactive containerized wastes and analyzing liquids that are collected in a storage area. Waste management personnel should consult Appendix V of 40 CFR Part 264 for groupings of wastes that cannot be stored in the same container. For more detail on sampling procedures and waste analysis methods, waste management personnel should consult the references at the end of this submodule.

It also is acceptable for the waste analysis plan to require the generator of the waste to complete a detailed chemical and physical analysis of a representative sample of the waste prior to waste management personnel accepting the waste into container storage.

However, if the generator does not supply the requisite information, and DOE accepts the waste, waste management personnel operating the container storage areas are responsible for obtaining or developing the waste analysis information.

NOTE: Approved waste analysis procedures for certain radioactive mixed waste have not yet been developed. Also, for some of DOE's radioactive mixed waste streams, compliance with the normal RCRA waste analysis requirements could result in radiological exposures to workers that exceed applicable AEA occupational exposure standards found in DOE Order 5480.11. In such cases, DOE field offices should seek agreement with EPA or a State on an alternative requirement (pursuant to RCRA Section 1006(a), which defers to the AEA in the event of inconsistent requirements). Such an alternative may involve using remote sensing, $a$ smaller sample size, or process knowledge to determine waste composition.

Before treating, storing, or disposing of hazardous waste, waste management personnel, or the generator if specified in the written waste analysis plan, must obtain a detailed chemical and physical analysis of a representative sample of the waste.

The analysis may include data developed under 40 CFR Part 261 to determine if a waste is defined as hazardous, existing published data on the waste, or data on waste generated from similar processes.

The analysis must be repeated as necessary to ensure that the information is accurate and up to date. 
Conbinuad from Stp 4

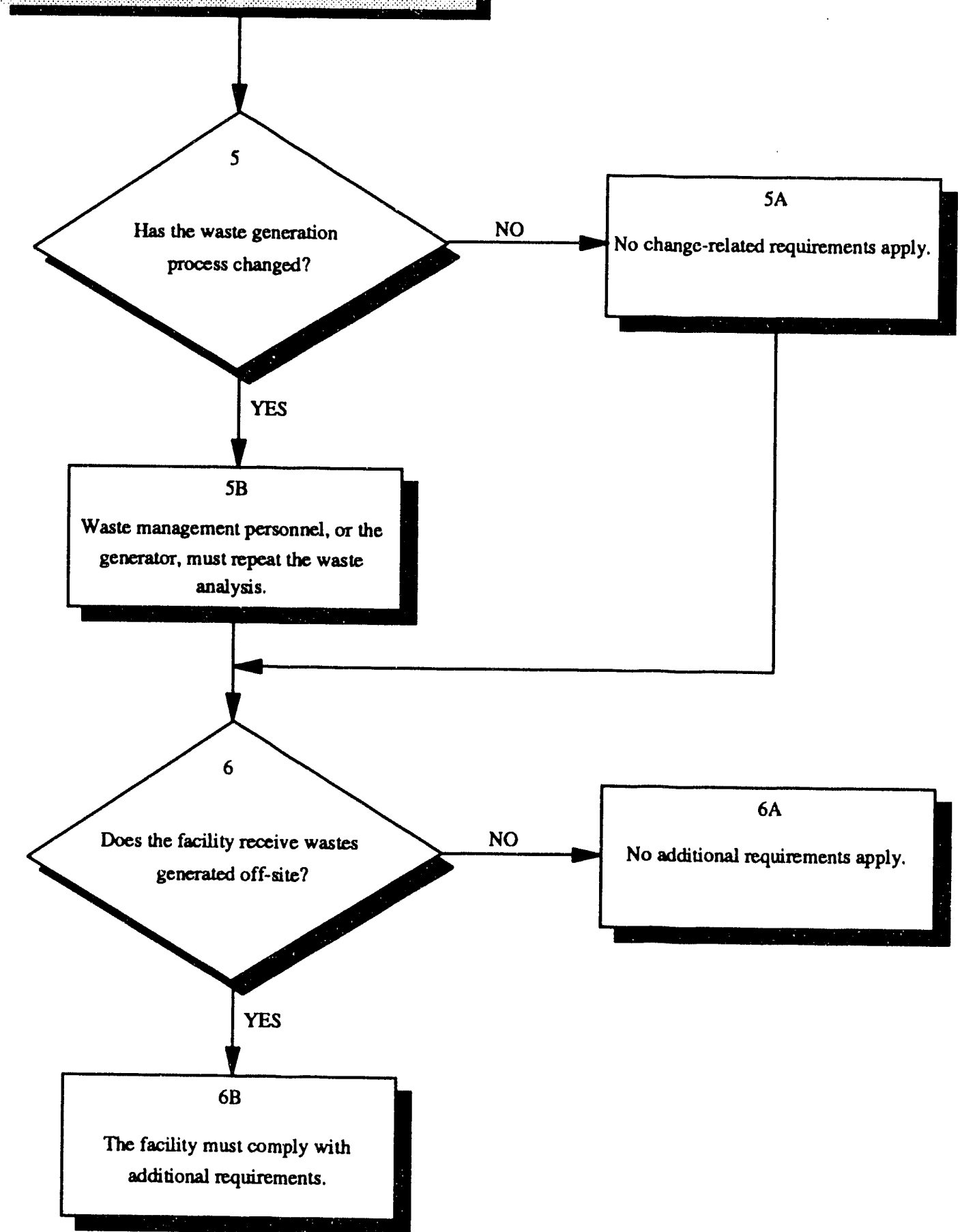


Step 5 Waste management personnel, or the generator as appropriate, must determine whether the waste generation process has changed in a manner that could potentially affect waste composition.

Step 5A If the process has not changed, waste management personnel or the generator must continue to conduct waste analyses as necessary, as determined in Steps 3 and 4.

Step 5B The waste analysis must be repeated if a change in the waste generation process occurs that could potentially affect waste composition.

Step 6 The facility must comply with additional chemical and physical waste analysis requirements (40 CFR 264.13(a)(4)) if it receives hazardous waste from off-site (i.e., waste that was gencrated elsewhere).

Step 6A If no waste is received from off-site, no further requirements apply.

Step 6B If, upon receipt of hazardous waste at a container storage area from an off-site generator, the mandatory analysis of the waste received reveals that waste does not correspond with information on the manifest or shipping papers, then the waste analysis must be repeated. See the discussion in Submodule 3.6, "Manifesting," on manifesting discrepancies for further requirements when a discrepancy is detected.

\section{REFERENCES FOR SUBMODULE 3.1}

1) Preparation of RCRA Waste Analysis Plans, (Interim Guidance), U. S. Department of Energy, Office of Environmental Guidance, RCRA/CERCLA Division, DOE/EH-0306, March 1993.

2) Radioactive Waste Management, U.S. Department of Energy, DOE Order 5820.2A, September 26, 1988.

3) Test Methods for Evaluating Solid Waste, Vohme II, U.S. Environmental Protection Agency, Office of Solid Waste, SW-846, November 1986.

4) 40 CFR 264.13 - General waste analysis.

5) 40 CFR 264.17 -. General requirements for ignitable, reactive, or incompatible wastes.

6) 40 CFR 264.73 -. Operating record. 


\section{Module 3: Flowchart}

\section{SUBMODULE 3.2: COMPATIBILITY}

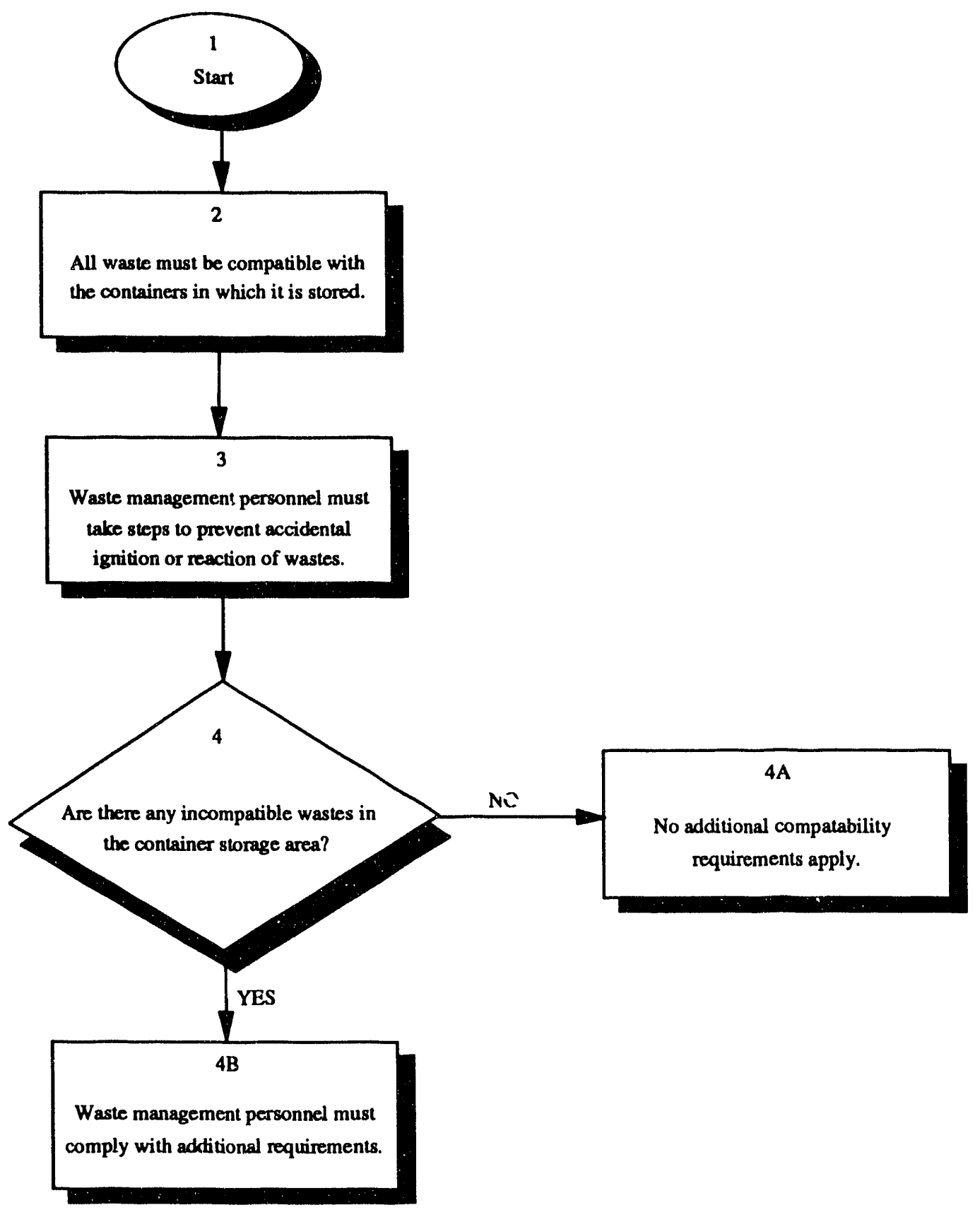


Step 1

Step 2

Step 3

Step 4

Step 4A

Step 4B
Start.

Materials must be compatible with the containers in which they are stored. For a material to be compatible with its container, it must not cause corrosion or decay of containment materials (40 CFR 261.22). To recognize different types of corrosion and factors influencing corrosion, such as temperature, $\mathrm{pH}$, and oxidizing agents, waste management personnel should consult: Compatibility of Wastes in Hazardous Waste Management Facilities, U.S. Environmental Protection Agency, Office of Solid Waste, 1982. The document also provides methods for evaluating and selecting structural material (e.g., 304 stainless steel) and lining material as well as a compatibility chart for chemicals versus different structural materials.

Waste management personnel must take precautions to prevent accidental ignition or reaction of ignitable or reactive waste at container storage areas. These wastes must be handled so as to prevent damage to the structural integrity of a device or the facility or otherwise threaten human health or the environment. Containers holding ignitable or reactive waste must be located at least 50 feet (15 meters) from the facility property line (i.e., not the boundary of the container storage area). Waste management personnel should take precautions to prevent accidental ignition or reaction of these wastes by separating and protecting them from open flames, smoking, cutting and welding, hot surfaces, frictional heat, sparks, spontaneous ignition, and radiant heat. National Fire Protection Association (NFPA) standards for flammable and combustible materials should be applied when storing ignitable or reactive waste. (See Submodule 4.3, "Spill Response," for a discussion of contingency plans and emergency procedures for hazardous waste management facilities.)

Incompatible wastes, if brought together, could result in heat generation, toxic gas generation, and/or explosions. Waste management personnel must therefore determine if any incompatible wastes exist at the container storage area. ${ }^{1}$

If all wastes at the facility are compatible, then no further requirements apply.

Hazardous waste must not be placed in an unwashed container that previously held an incompatible waste or material. Further, a storage container holding waste that is incompatible with any waste or materials stored near other containers must be separated from the other materials by a dike, berm, wall, or other device.

${ }^{1}$ Incompatible wastes stored in containers must not, upon ultimate disposal, be placed in the same landfill cell, unless measures are taken (e.g., walls, berms, etc.) to prevent uncontrolled commingling of the waste (40 CFR 265.313). 


\section{REFERENCES FOR SUBMODULE 3.2}

1) A Method for Determining the Compatibility of Hazardous Wastes, U.S. Environmental Protection Agency, EPA-600/2-80-076, 1980.

2) Compatibility of Wastes in Hazardous Waste Management Facilities, U.S. Environmental Protection Agency, Office of Solid Waste, November 1982.

3) Waste Analysis Plans, U.S. Environmental Protection Agency, Office of Solid Waste, EPA/530-SW-84-012, October 1984.

4) 40 CFR 264.17 -. General requirements for ignitable, reactive, or incompatible wastes.

5) 40 CFR 264.172 -- Compatibility of waste with containers.

6) 40 CFR 264.177 -- Special requirements for incompatible wastes.

7) Ignitable and Combustible Liquid Code, Fire Protection Association, NFPA 30. 
[This page intentionally blank] 


\section{Module 3: Flowchart}

\section{SUBMODULE 3.3: GENERAL CONTAINER MANAGEMENT PRACTICES}

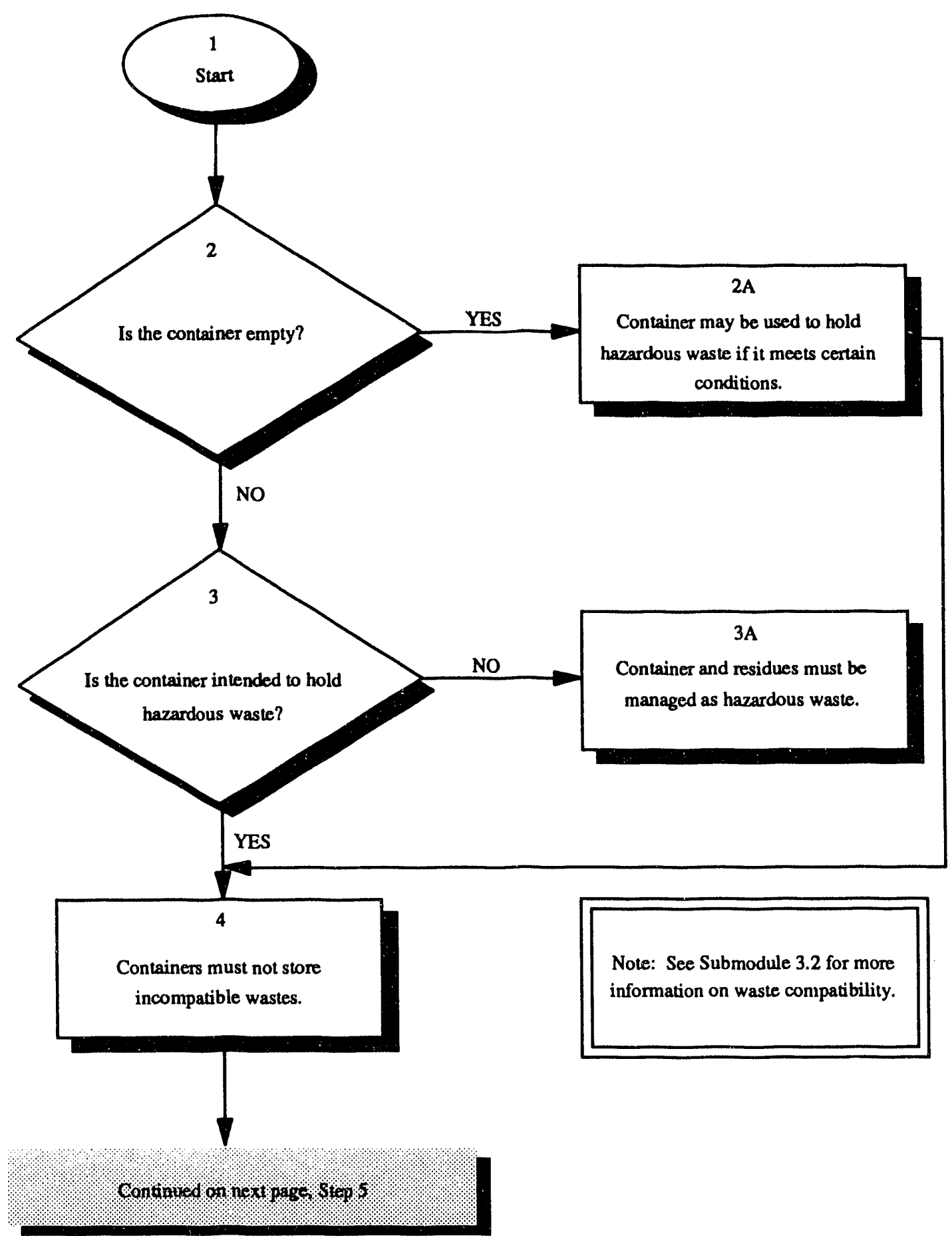


Step 1

Step 2

Step 2 A

Step 3

Step 3A

Step 4
Start.

For a discussion of what constitutes an empty container, see Module 1, "Applicability."

Empty containers, subject to the conditions outlined below, may be used to store hazardous or radioactive mixed wastes. Reuse of containers in transporting hazardous and radioactive mixed waste is governed by DOT regulations, in particular 49 CFR 173.28.

Regardless of whether the containers are intended to store hazardous or radioactive mixed waste, waste management personnel must comply with restrictions on the use of containers that are not empty.

The containers and all residues must be managed as hazardous waste in accordance with all applicable requirements of 40 CFR 262 through 266, unless waste management personnel can demonstrate that the container and residues are not hazardous. For information on how such demonstrations can be made (e.g., triple rinsing of containers), see 40 CFR 261.7.

When reusing containers, hazardous or radioactive mixed wastes must not be stored that are incompatible with either the container, or the remaining waste residues, if any are present. See Submodule 3.2, "Compatibility," for a discussion of compatibility. 


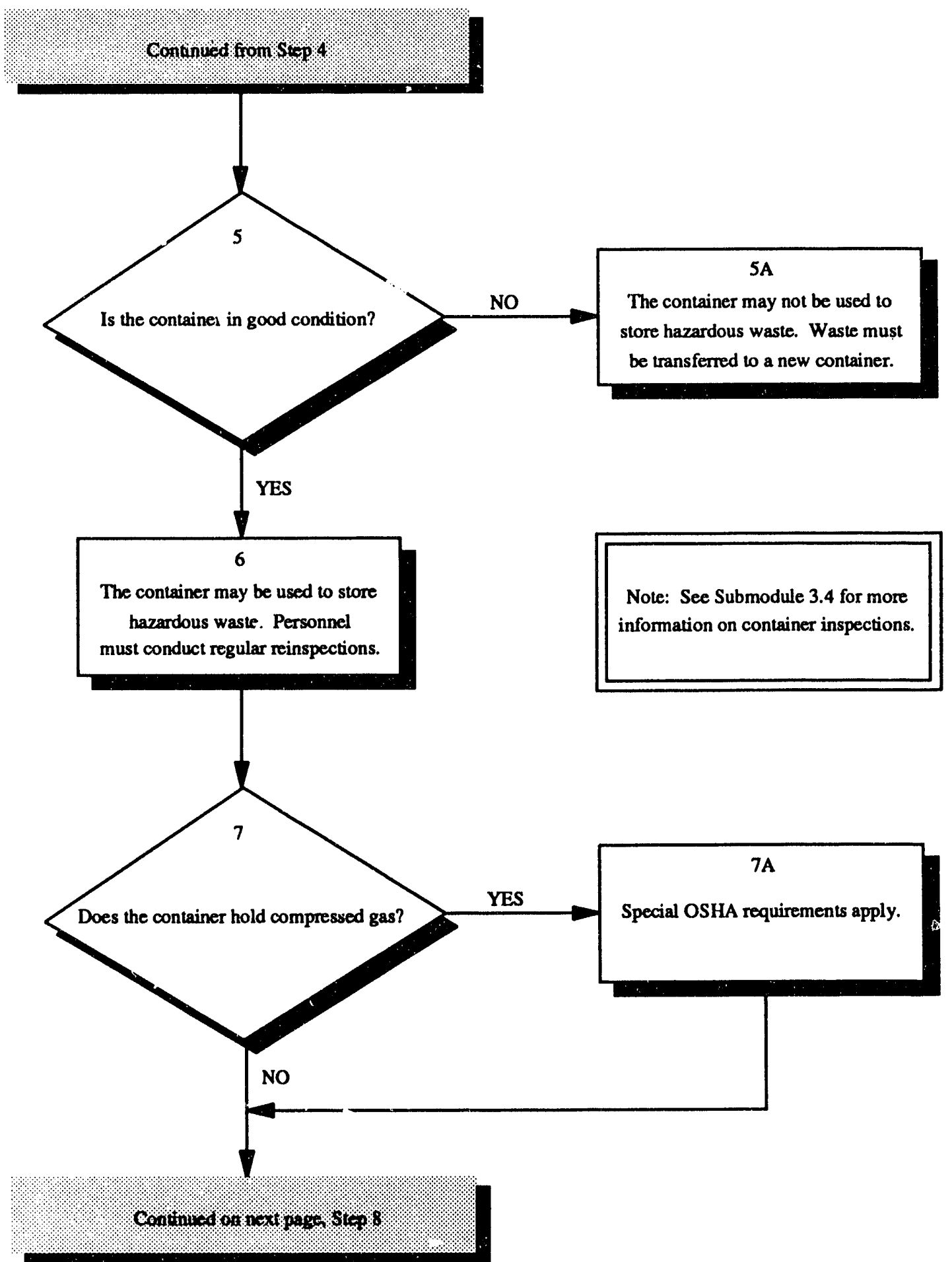


Step 5

Step 5A

Step 6

Step 7

Step 7A

Waste management personnel should consult the following sections oi 29 CFR for OSHA requirements applicable to compressed gases:

- $\quad$ General OSHA requirements for gases -- 29 CFR 1910.101;

- $\quad$ OSHA requirements for acetylene -- 29 CFR 1910.102;

- $\quad$ OSHA requirements for hydrogen -- 29 CFR 1910.103;

- OSHA requirements for oxygen -- 29 CFR 1910.104; and

- $\quad$ OSHA requirements for nitrous oxide -- 29 CFR 1910.105. 


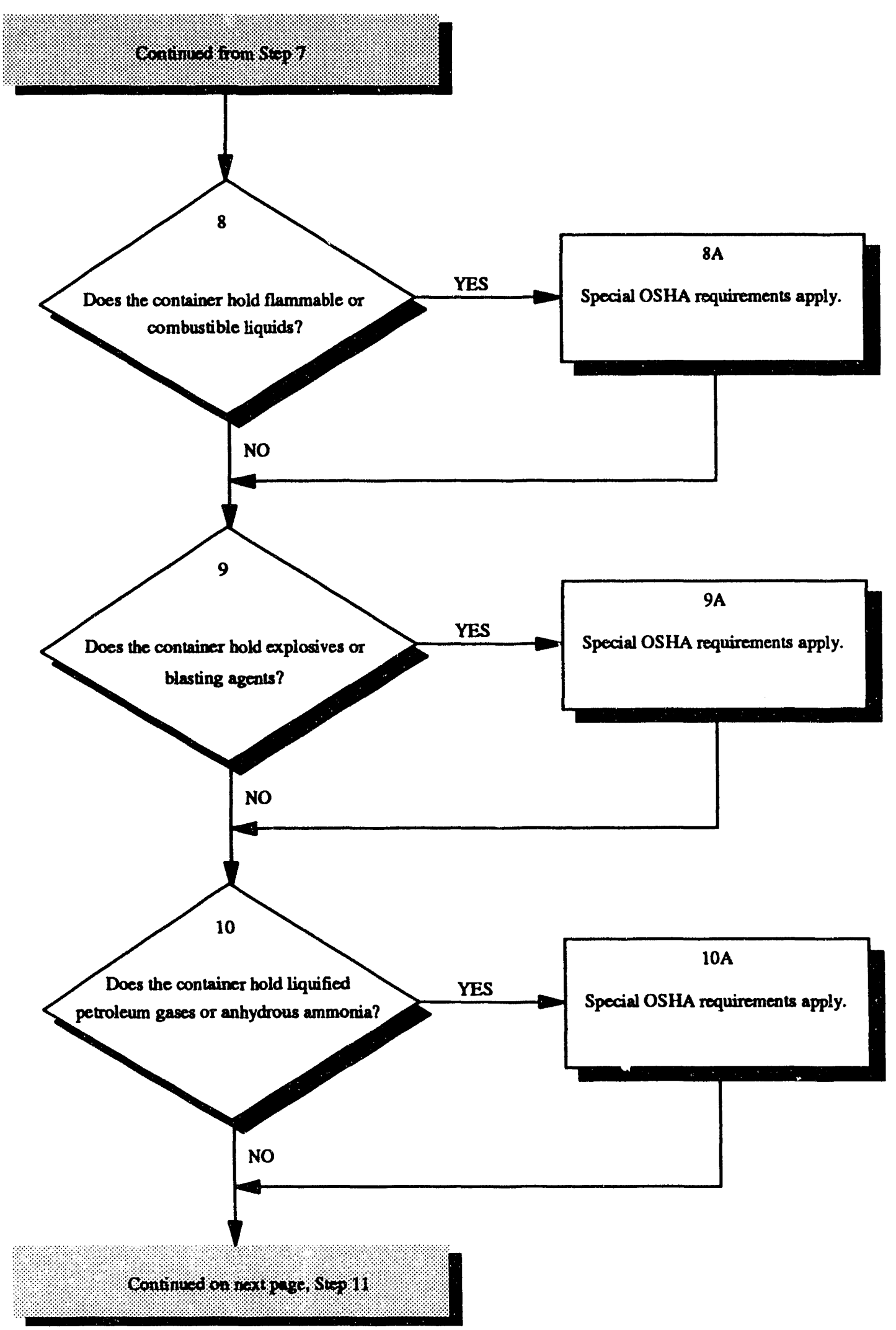


Step 8

Step 8A

Step 9

Step 9A

Step 10

Step 10A
OSHA regulations define "flammable liquid" as any liquid having a flashpoint below $100^{\circ} \mathrm{F}$ and a "combustible liquid" as any liquid having a flashpoint at or above $100^{\circ} \mathrm{F}$ with an upper flashpoint limit of $200^{\circ} \mathrm{F}$ (29 CFR 1910.106(a)(18) \& (a)(19)).

Waste management personnel should consult 29 CFR 1910.106 for OSHA requirements applicable to flammable and combustible liquids.

OSHA regulations define "explosive" as any chemical compound, mixture or device, the purpose of which is to function by explosion (29 CFR 1910.109(a)(3)). A "blasting agent" is defined as any material or mixture, consisting of a fuel and an oxidizer, intended for blasting, not otherwise classified as an explosive, and in which none of the ingredients are classified as explosives, provided that the finished product cannot be detonated by a No. 8 test blasting cap when unconfined (29 CFR 1910.109(a)(1)).

Waste management personnel should consult 29 CFR 1910.109 for OSHA requirements applicable to explosives and blasting agents.

OSHA regulations define "liquid petroleum gases" as any material which is composed predominantly of the following hydrocarbons or mixtures thereof: propane, propylene, butane, and butylene (29 CFR $1910.110(a)(7))$. Special OSHA requirements also apply to anhydrous ammonia.

Waste management personnel should consult 29 CFR 1910.110 for OSHA requirements applicable to liquid petroleum and 29 CFR 1910.111 for anhydrous ammonia requirements. 


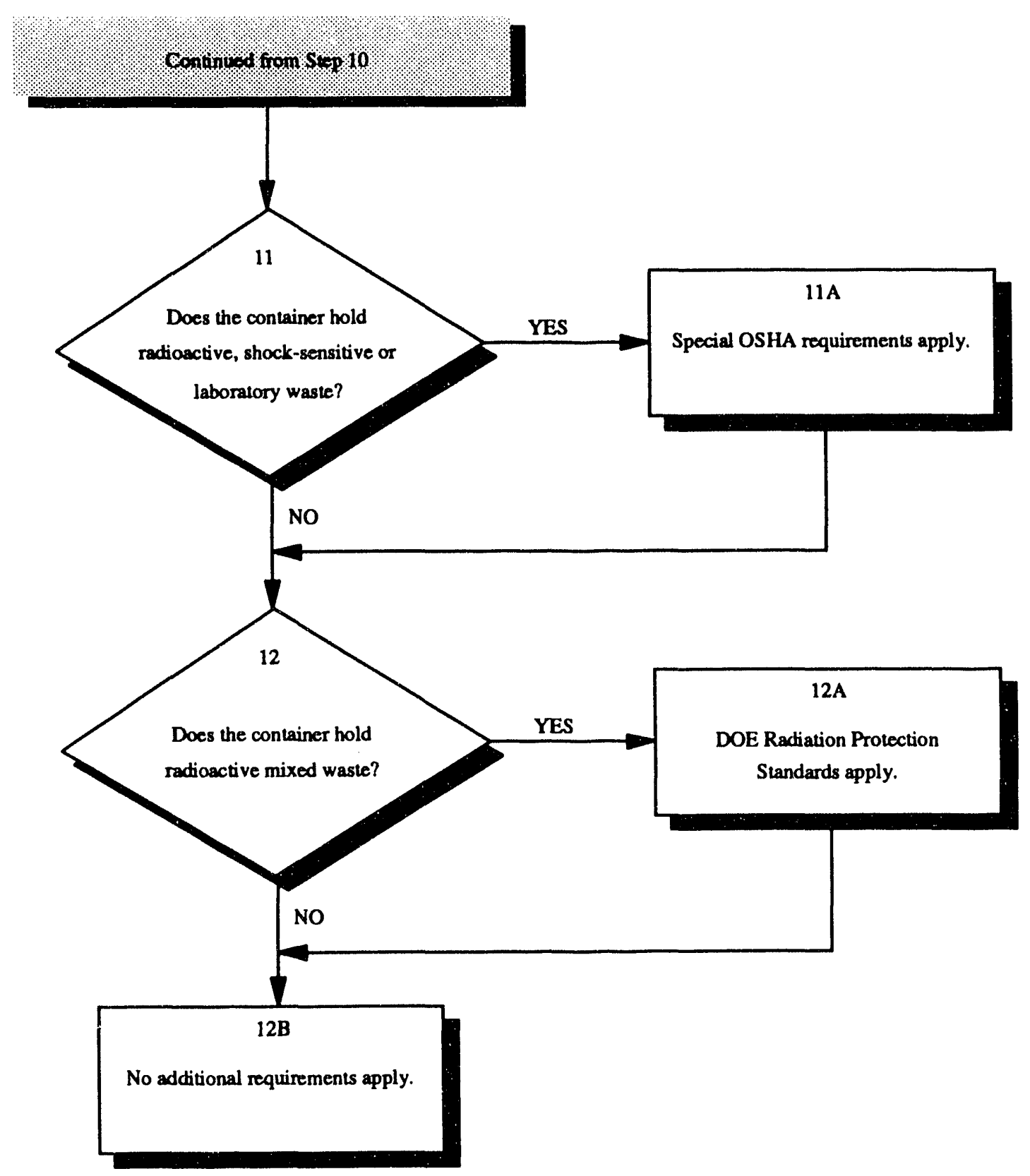


Special requirements apply for radioactive, shock-sensitive, and laboratory waste. Shocksensitive wastes are wastes that may react violently (i.e., explode) when jarred. Laboratory wastes do not necessarily originate from a laboratory, but rather consist of containers holding smaller individual containers of hazardous waste.

Step 11A Waste management personnel should consult 29 CFR 1910.120(j) for special OSHA requirements applicable to radioactive, shock sensitive, and laboratory wastes.

Step 12 Waste management personnel must determine whether any of the containers in the container storage area contain radioactive mixed waste.

Step 12A If the containers hold radioactive mixed waste, waste management personnel must not be exposed to radiation in excess of radiation protection standards specified in DOE Order 5480.11 Radiation Protection for Occupational Workers.

Step 12B No further general container management practices apply.

\section{REFERENCES FOR SUBYODURE 33}

1) Hazardous and Radioactive Mixed Waste Program, U.S. Department of Energy, DOE Order 54003, February 22, 1989.

2) Radioactive Waste Management, US, Department of Energy, DOE Order $5820.2 A$, September 26,1988 .

3) 40 CFR 264 Subpart B - General facility standards.

4) 40 CFR 264 Subpart C - Preparedness and prevention.

5) 40 CFR 264 Subpart D - Contingency plan and emergency procedures.

6) 40 CFR 264.171 - Condition of containers.

7) 40 CFR 264.173 - Management of containers.

8) 40 CFR 264.176 - Special requirements for ignitable or reactive waste.

9) 29 CFR 1910 Subpart $\mathrm{H}-$ Hazardous materials. 


\section{Module 3: Flowchart}

\section{SUBMODULE 3.4: INSPECTIONS}

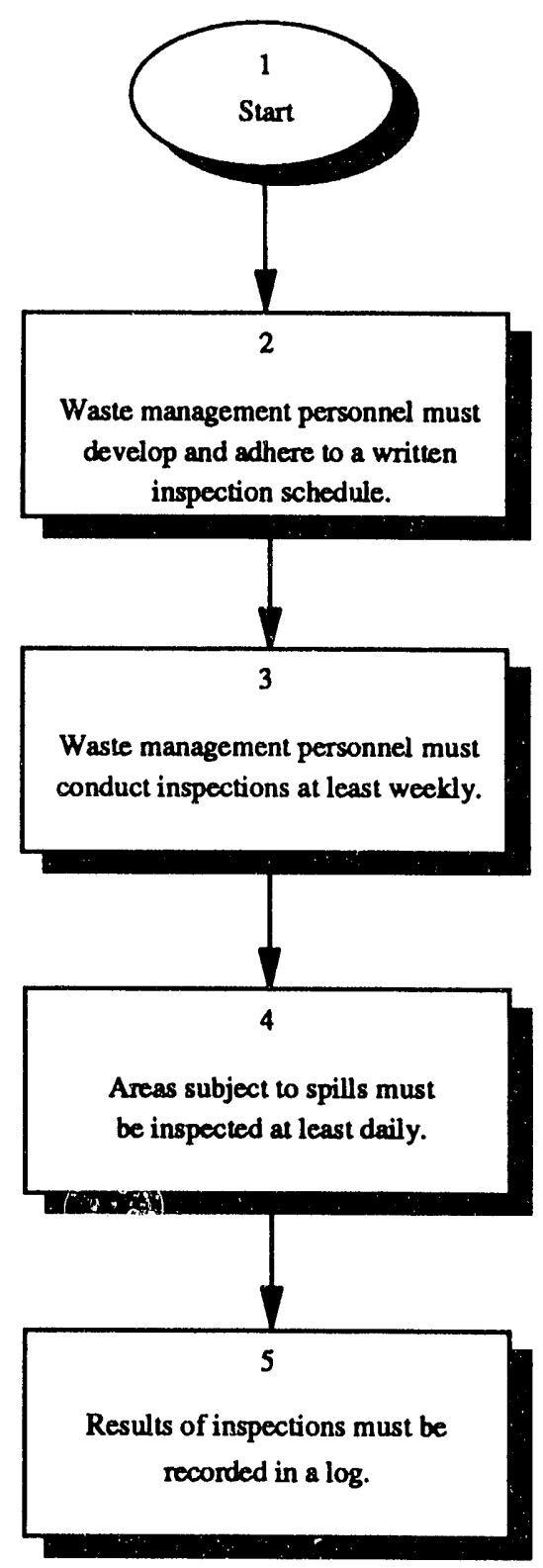

Note: Radiation Protection Standards under AEA may not allow compliance with normal RCRA container inspection requirements. 
Step $1 \quad$ Start.

Step 2 Waste management personnel must develop and adhere to a written schedule for container inspections. The schedule must identify the types of potential problems (e.g., deteriorating containers or containment systems, improper container handling procedures) to be looked for during inspection and must be kept at the DOE operating facility. The inspection schedule must be submitted as part of the permit application and may be amended by the Regional Administrator or State Director (40 CFR 264.15 and 265.15).

Step 3 Under RCRA, inspections of container storage areas are normally conducted at least weekly to detect any leaking or deteriorating containers, faulty equipment, or deteriorating containment systems as early as possible. Operating personnel should visually inspect the containers in the storage area to detect any problems that may pose a threat to human health and the environment. The inspector should examine the surface of the containers for signs that their structural integrity has deteriorated. In particular, the inspector should check for corrosion, swelling, excessive dents, cracks, punctures, or any other signs of deterioration (e.g., liquid on the surface of a container, leaks, spills). Containers should not be left open and should be handled in such a way as to minimize the potential for rupture. See Exhibit 3.4.1 for an example of a RCRA container storage area inspection checklist.

When conducting an inspection, waste management personnel should evaluate the security around the unit, determine whether there is sufficient aisle space, check for dead vegetation or stains in the storage run-off area, ensure that safety and emergency equipment is in proper working order, verify that evidence of past spills correlates with the operating record, and look for any drums that are being stored in an unauthorized area. An owner or operator must have a waiver from the local community fire marshal for storing containers of ignitable or reactive waste within 15 meters of the property boundary, but inside the storage facility structure. The inspector should also verify that the containment system is free from cracks, gaps, or other signs of deterioration and is without any standing liquids.

NOTE: For some of DOE's radioactive mixed waste streams, compliance with the normal $R C R A$ container inspection requirements could result in radiological exposures to workers that exceed applicable AEA occupational exposure standards found in DOE Order 5480.11. In such cases, DOE operations offices could seek agreement with EPA or a State on an alternative requirement (pursuant to RCRA Section 1006(a), which defers to the AEA in the event of inconsistent requirements). Such an alternative could require DOE to conduct less frequent visual inspections, but use robotics, video cameras, and release detection equipment rather than workers to ensure the integrity and condition of containers in storage.

Step 4 Areas subject to spills, such as loading and unloading areas and accumulation sites must be inspected daily when in use.

Step 5 All inspections must be recorded in an inspection log that must be maintained for at least three years from the date of inspection. The inspection log must contain the date and time of inspection, the name of the inspector, a summary of any observations made during the inspection, and the date and nature of any repairs or other actions taken to address problems noted. 


\section{REFERENCES FOR SUBMODULE 3.4}

1) Inspections of RCRA Container Storage Areas, U. S. Department of Energy, Office of Environmental Guidance, RCRA/CERCLA Division, Information Brtef, EH-231-033/0793, July 1993.

2) Federal Environmental Inspection Handbook, U.S. Department of Energy, Office of Environmental Guidance, RCRA/CERCLA Division, Guidance Manual, DOE/EH-0220, October 1991.

2) Multi-Media Compliance Audit Procedures, U.S. Environmental Protection Agency, National Enforcements Investigation Center, EPA-330/9-89-003-R, March 1989.

3) RCRA Inspection Manual, U.S Environmental Protection Agency, Office of Waste Programs Enforcement, 0SWER 9938.2A, March 1988.

25) 40 CFR 264.15 and 265.15 - General inspection requirements.

6) $40 \mathrm{CFR} 264.174$ and 265.174 - Inspectlons of container storage areas. 


\section{Exhibit 3.4.1 \\ Inspection Checklist for RCRA Container Storage Areas}

Section A -- Use and Management

1. Are containers in good condition?

_Yes _ No

Section B -. Compatibility of Waste With Container

1. Is container made of a material that will not react with the waste which it stores?

_Yes _. No

\section{Section C -- Management of Containers}

1. Is container always closed while holding hazardous waste?

_Yes _No

2. Is container handled so that it will not be opened, handled, or stored in a manner which may rupture it or cause it to leak?

\section{Section D .- Inspections}

1. Does owner/operator inspect containers at least weekly for leaks and deterioration?

Yes _ No

Section E -. Containment (Part 264)

1. Do container storage areas have a containment system?

Yes _ No

Section F -- Ignitable and Reactive Waste

1. Are containers holding ignitable and reactive waste located Yes No at least $15 \mathrm{~m}(50 \mathrm{ft})$ from facility property lines?

Section G -. Incompatible Waste

1. Are incompatible wastes or materials placed in the same Yes_No containers?

2. Are hazardous wastes placed in washed, clean containers when they previously held incompatible waste?

_Yes_No

\section{Exhibit 3.4.1}




\section{Inspection Checklist for RCRA Container Storage Areas (cont.)}

3. Are incompatible hazardous wastes separated from each other _ Yes _. No by a berm, dike, wall, or other device?

\section{Section H -. Closure (Part 264)}

1. At closure, were all hazardous wastes and associated residues removed from the containment system?

Yes No No 
[This page intentionally blank] 


\section{Module 3: Flowchart}

\section{SUBMODULE 3.5: PERSONNEL TRAINING}

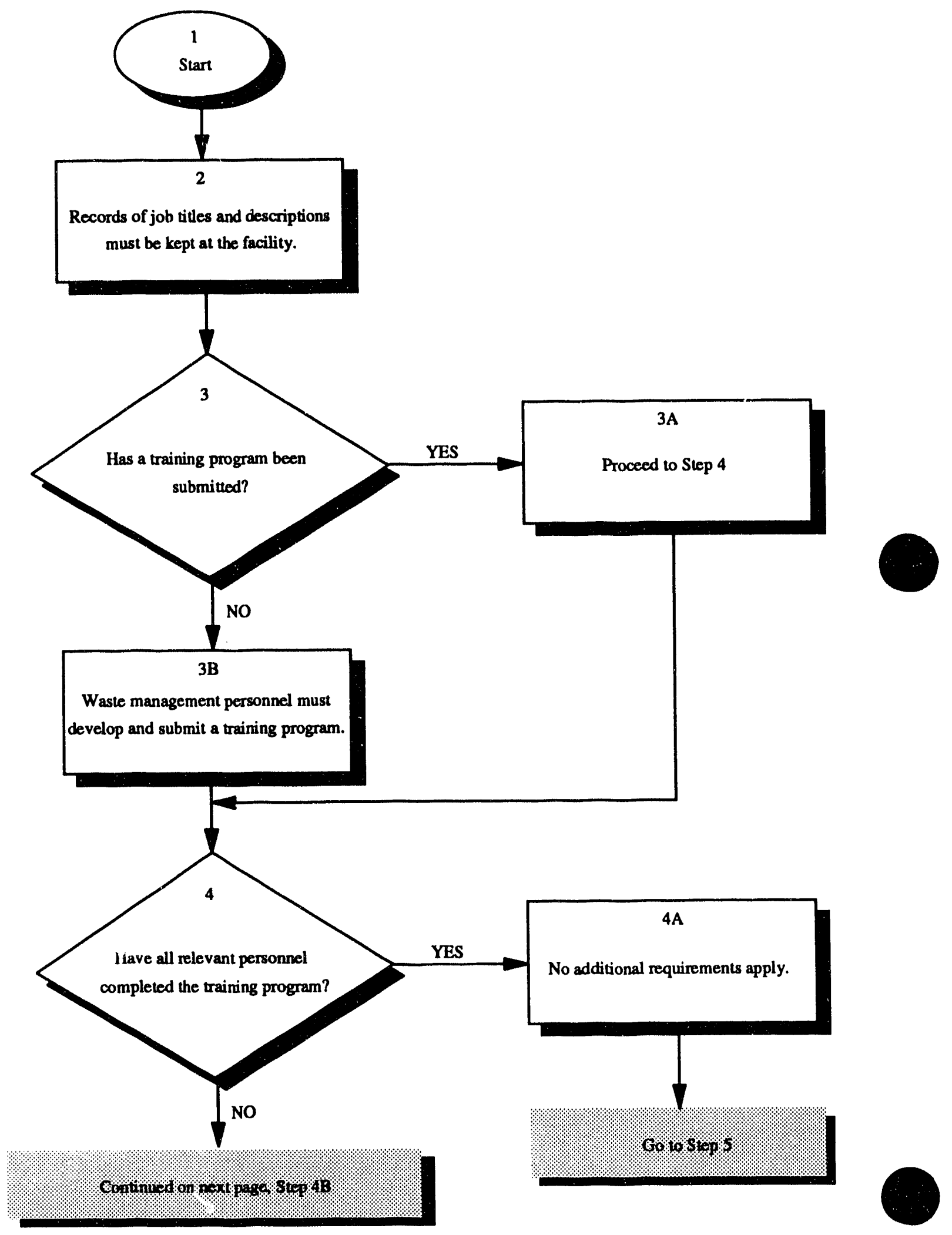


Step 1 Start.

Step 2 Waste management personnel must keep records listing job titles and descriptions for all positions at the container storage area and the names of the employees filling each position. Waste management personnel must also keep records of all training programs for each affected employee until closure of the container storage area. Records on former employees must be kept for at least three years from the date the employee last worked at the container storage area (40 CFR 264.16 and 265.16).

Step 3 As part of the RCRA Part B permit application, waste management personnel must develop and submit an outline of both introductory and continuing training programs and a brief description of how the training programs are designed to meet actual job tasks (40 CFR 264.16 (a)(1) and Part 270).

Step 3A If a training program for the container storage area(s) has been submitted, proceed to Step 4.

Step 3B The training program must enable all personnel at the container storage area to respond effectively to emergencies by teaching them about emergency procedures, equipment, and emergency systems, including responses to ground-water contamination incidents, shutdown of operations, and procedures for using, inspecting, repairing, and replacing facility emergency and monitoring equipment. In addition, operating personnel should consult OSHA training requirements contained in 29 CFR 1910.120(e) for more details (e.g., minimum number of hours, trainer qualifications, certifications).

Step 4 "All operating personnel working at the container storage area must complete a training program within six months after the date of their employment or assignment to the container storage area, or to a new position at a facility. Note that training may be conducted at a facility-wide level, rather than for the container storage area alone.

Step 4A If all relevant personnel have completed the required training, proceed to Step 5. 


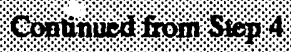

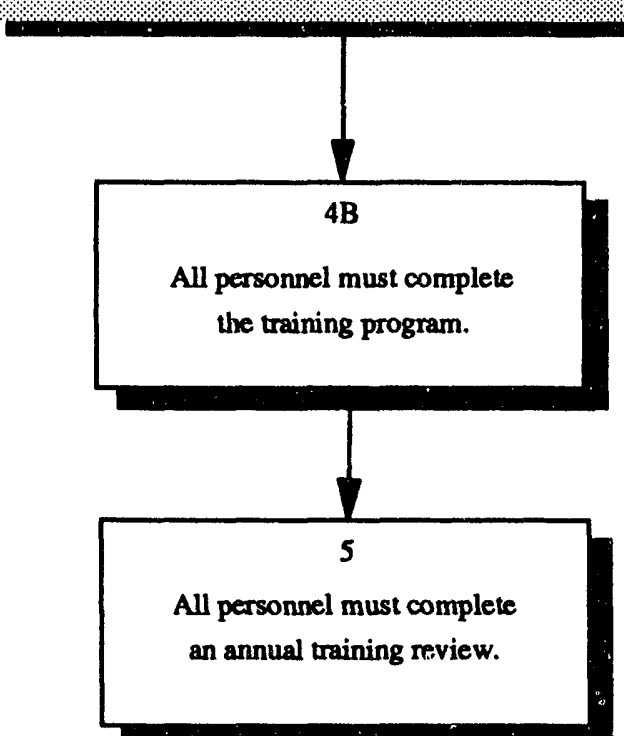


All relevant operating personnel must successfully complete either classroom instruction or on-the-job training to perform his/her duties in a way that ensures the container storage area's compliance with all applicable requirements. The training program must be directed by a trainer knowledgeable in hazardous waste management procedures.

Step 5

All operating personnel must participate in an annual review of the initial training.

\section{REFERENCES FOR SUBMODULE 3.5}

1) Training Accreditation Program (TAP1), U.S. Department of Energy, Office of the Assistant Secretary for Environment, Safety, and Health, March 1, 1989.

2) 29 CFR 1910.106 -- Flammable and combustible liquids.

3) 40 CFR 264.16 -- Personnel training.

4) 40 CFR 270.14 -- Contents of Part B permit application: General requirements.

5) OSHA Training Requirements for Hazardous Waste Operations, U.S. Department of Energy, Office of Environment, Safety, and Health, RCRA/CERCLA Division, Guidance Manual, DOE/EH-0227P, December 1991. 


\section{Module 3: Flowchart}

\section{SUBMODULE 3.6: MANIFESTING AND RECORDKEEPING}

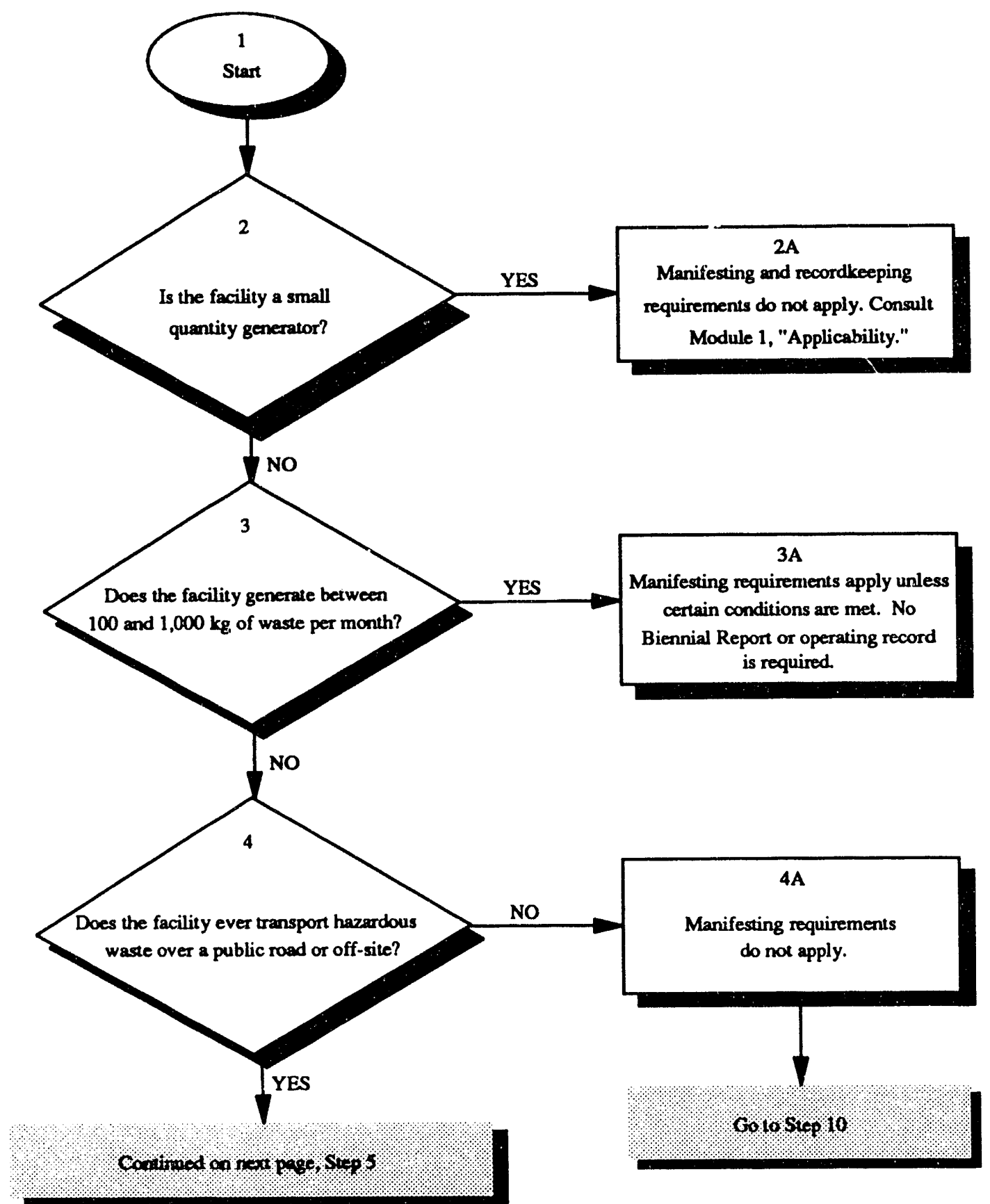


Step $1 \quad$ Start.

Step 2 Waste management personnel should consult Module 1, "Applicability," to determine if the facility meets the conditionally exempt small quantity generator exclusion requirements.

Step 2A Facilities included in the conditionally exempt small quantity generator exclusion need not comply with RCRA manifesting requirements, nor are they required to submit a Biennial Report or maintain an operating record (see Step 4 below).

Step 3 Waste management personnel should refer to Module 1, "Applicability," to determine if the $100 \mathrm{~kg}$ to $1,000 \mathrm{~kg}$ generator exclusions apply.

Step 3A DOE facilities that generate between $100 \mathrm{~kg}$ and $1,000 \mathrm{~kg}$ of hazardous waste in a calendar month must comply with the manifesting requirements unless both of the following requirements are met (40 CFR 262.20(e)):

- the waste is reclaimed under a contractual agreement that specifies the type of waste and frequency of shipments, provided that the transportation vehicle is owned and operated by the reclaimer of the waste; and

- waste management personnel maintain a copy of the reclamation agreement for a period of at least three years after termination or expiration of the agreement.

These facilities are not required to submit a Biennial Report nor maintain an operating record (see Step 4 below). However, these facilities must maintain records of waste analyses and comply with additional reporting requirements of 40 CFR 262.43 as directed by the Regional Administrator.

Step 4 Generators are not subject to the RCRA manifesting requirements if (1) they generate hazardous waste, but treat, store, and dispose of all such hazardous waste on-site and do not transport it on a public road; and (2) they do not receive any hazardous waste from off-site sources.

Step 4A While these container storage areas are not subject to the manifesting requirements, they must comply with all applicable requirements for TSDFs, including operating record, biennial reporting, and other reporting requirements of 40 CFR Parts 264 and 265, Subpart E. 


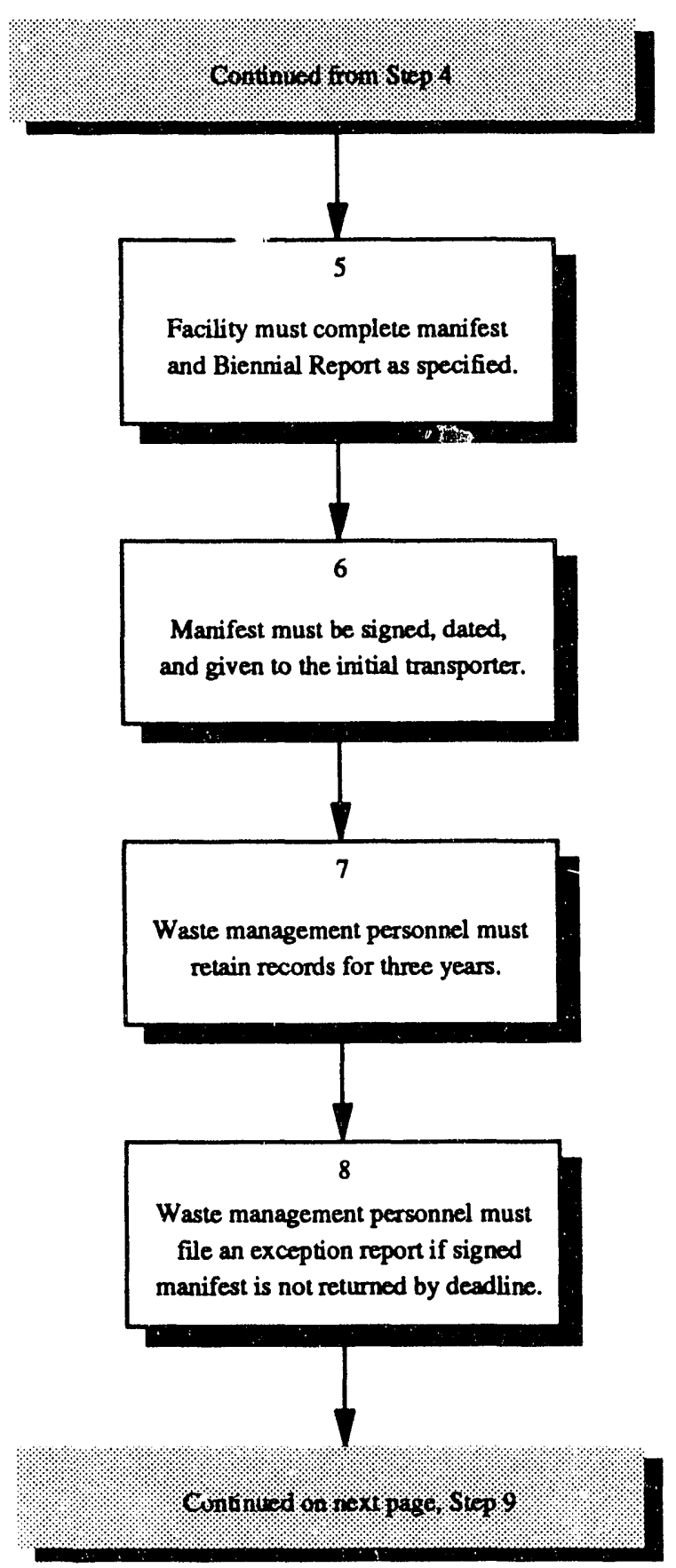


Facilities that do not qualify for an exemption from these regulations must prepare a Manifest, OMB control number 2050-0039, using EPA form 8700-22 (a uniform hazardous waste manifest) and EPA form 8700-22A (continuation sheet), if necessary (40 CFR 262.20(a)) or equivalent State forms. A manifest is a critical document that allows DOE to track the movement of hazardous waste from the point of ge _eration to the point of ultimate treatment, storage, or disposal. The manifest contains information such as the names and EPA ID numbers of the generator, transporter, and the treatment, storage, or disposal facility; DOT waste codes; quantities of waste being transported; and the location of the ultimate destination for the hazardous or radioactive mixed waste. DOE facilities musc use the manifest required by the State to which the shipment is manifested. If that State does not supply the manifest, DOE must use the manifest required by the State in which the facility is located. If neither the generator State nor the consignment State supply the manifest, then DOE may obtain a manifest from any source (40 CFR 262.21).

The manifest must consist of enough copies for the generator, each transporter, and the designated facility to each retain one copy, and an additional copy to be returned to the generator (40 CFR 262.22). Waste management personnel must designate on the manifest one facility which is permitted to manage the waste accompanied by the manifest. DOE may designate an alternate facility permitted to manage the waste in the event of an emergency. If a transporter is unable to deliver the waste to either of the facilities designated on the manifest, DOE must either designate another facility or instruct the transporter to return the waste to the point of generation. Examples of these manifest forms and instructions for completing them are included at the end of this submodule.

In addition, a generator shipping any hazardous waste off-site for treatment, storage, or disposal must prepare and submit a Biennial Report to the EPA Regional Administrator by March 1 of each even numbered year. The Biennial Report must be prepared and submitted in accordance with 40 CFR 262.41.

Step 6

Once the manifest is completed, the owner/operator, as the generator of the waste, must sign the manifest certification by hand, obtain the handwritten signature of the initial transporter, and retain one copy of the manifest for the facility files. The remaining copies of the manifest must be given to the initial transporter (40 CFR 262.23).

Step 7 The owner/operator must retain a copy of the original manifest for three years or until a signed copy of the manifest is received from the facility which eventually accepted the waste. This signed copy must be retained for at least three years from the date the waste was accepted by the initial transporter (40 CFR 262.40).

Step 8 For facilities generating more than 1,000 kilograms of hazardous waste in a calendar month, if 35 days pass from the date on which the original transporter accepted the waste and DOE has not received a manifest from the facility that ultimately received the waste, waste management personnel must contact the transporter and the cwner/operator of the designated facility. If $\mathbf{4 5}$ days pass and DOE still has not received a manifest from the designated facility, waste management personnel must file an exception report with the Regional Administrator of the EPA or State Director. The exception report must include the generator's copy of the manifest and must describe the efforts to locate the waste as well as the resuit of these efforts (40 CFR 262.42).

For facilities generating between 100 and 1,000 kilograms of hazardous waste in a calendar month, if 60 days pass from the date on which the original transporter accepted the waste and DOE has not received a manifest from the designated facility, operating per;onnel must submit a copy of the manifest, with some indication that the they have not received confirmation of delivery to the Regional Administrator or State Director. 


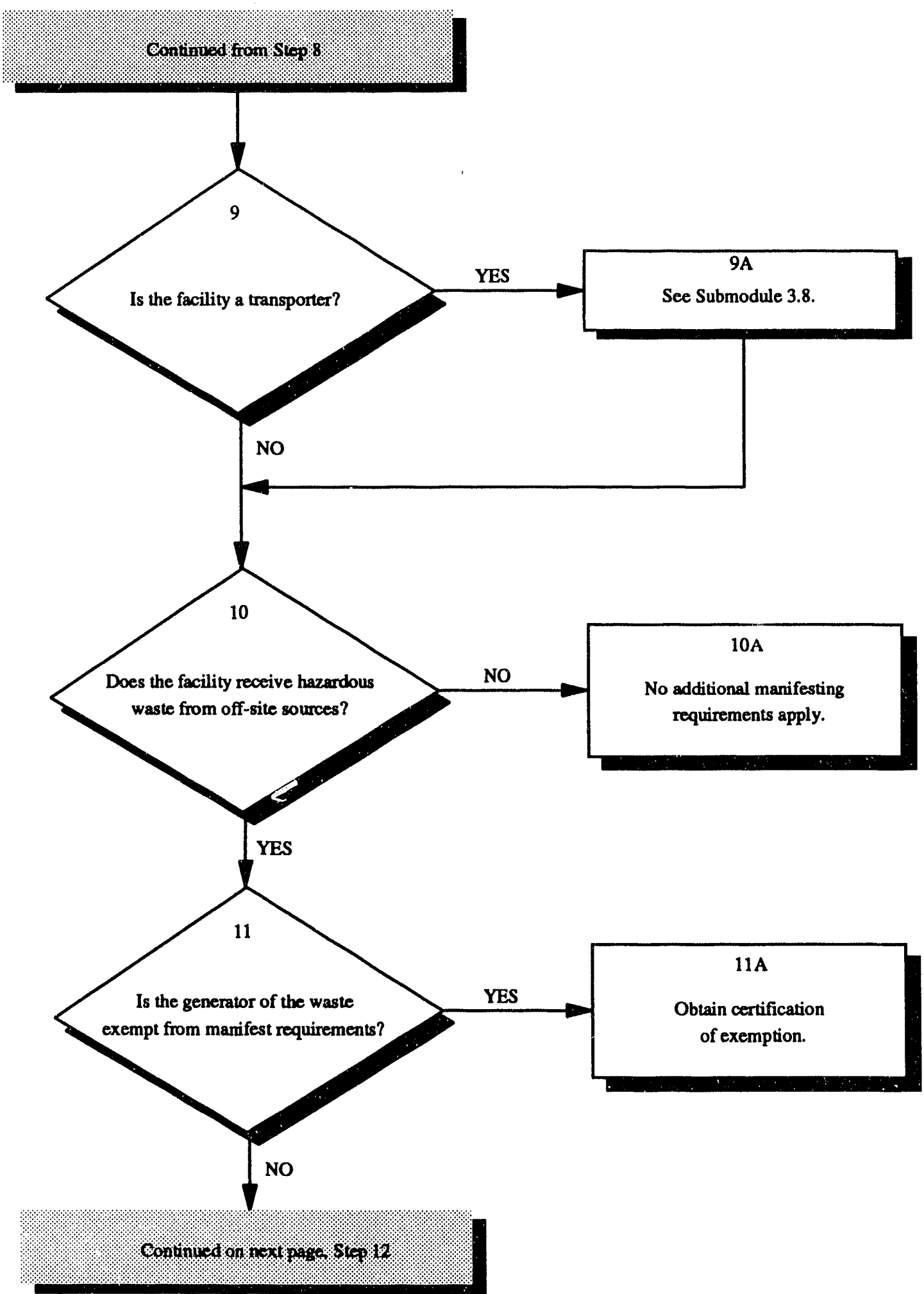


Generally, waste management personnel operating a container storage area must be concerned with transporter requirements if they transport hazardous materials in containers over public highways or property. Submodule 3.8, "Transportation," should be consulted to confirm whether the facility is a transporter.

Step 9A Transporter manifesting requirements are discussed in Submodule 3.8, "Transportation."

Step 10 If the container storage area is receiving hazardous waste from off-site sources, then the facility may have to comply with additional manifesting requirements, outlined below.

Step 10A If the container storage area is not receiving hazardous waste from off-site sources, then waste management personnel do not have to comply with manifesting requirements applicable to designated receiving facilities.

Step 11 Wastes received at a container storage area must be accompanied by a manifest or, if received from a rail or water (bulk shipment) transporter, a shipping paper (40 CFR 264.71(b)), unless the waste was generated by a facility which is exempt from the manifesting requirements (e.g., conditionally exempt small quantity generator).

Step 11A In cases where the hazardous waste is excluded from manifest requirements, waste management personnel should obtain a certification that the waste qualifies for exemption from the generator. 


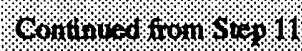

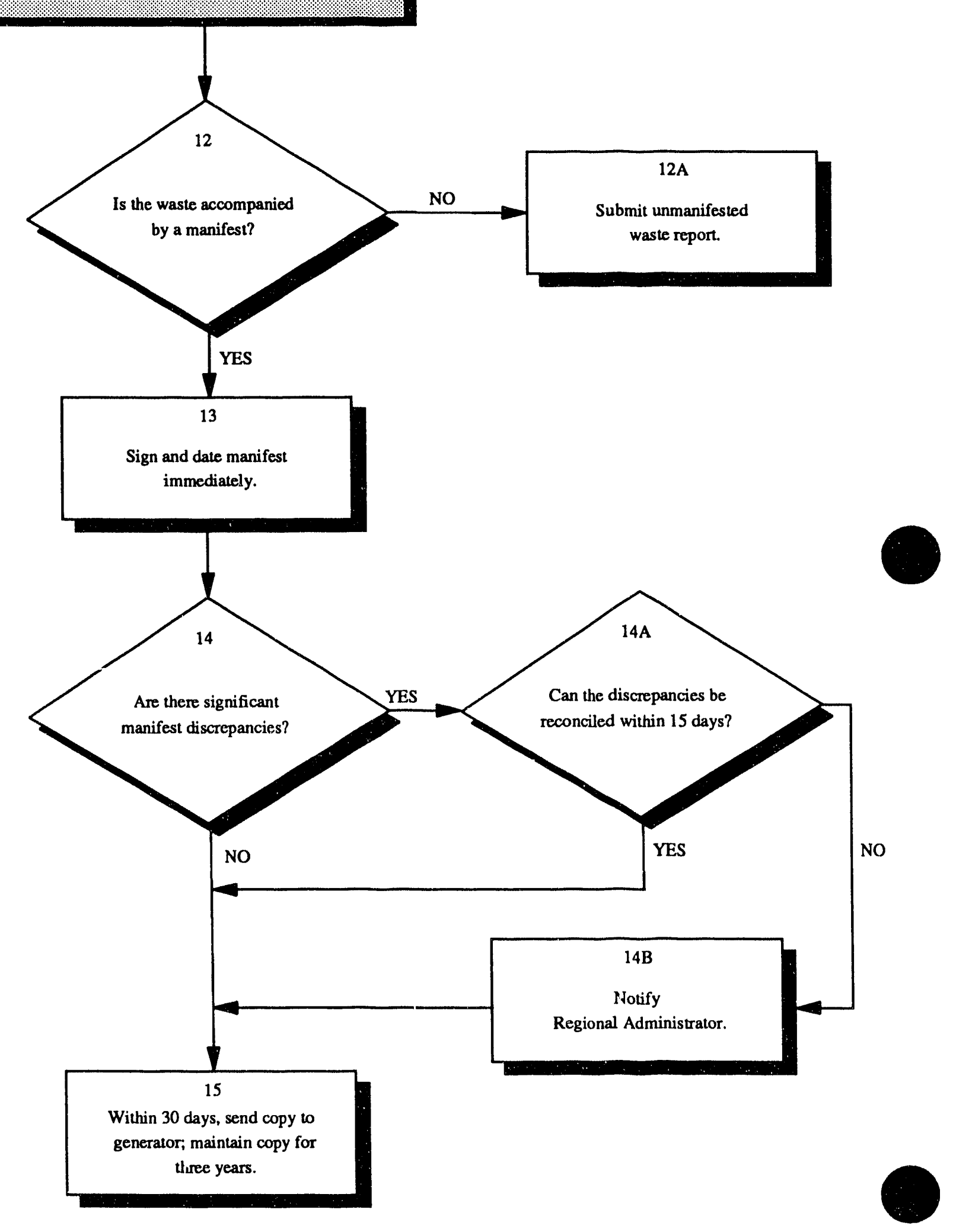


Upon receipt of waste which is not excluded from the manifest requirements, waste management personnel should determine whether a manifest or shipping paper accompanies the waste.

Step 12A If waste management personnel receive a shipment of hazardous waste that is unmanifested or which does not include a shipping paper, and if the waste is not exempt from the manifesting requirements (Steps 3 and 4), then personnel must submit to the appropriate Regional Administrator a single copy of the unmanifested waste report (EPA form 8700-13B). A copy of this form and instructions for completion are included at the end of this submodule.

Step 13 Upon receipt of a shipment of hazardous waste, waste management personnel must sign and date each copy of the manifest, or shipping paper if appropriate, note any discrepancies, and immediately give the transporter at least one signed copy.

Step 14 Significant discrepancies in quantity of waste are defined as "variations greater than 10 percent in weight and, for batch waste, any variation in piece count" (40 CFR 264.72 (a)). Significant discrepancies in waste type are defined as obvious differences that can be discovered by inspection or waste analysis or toxic constituents not reported on the manifest. Waste management personnel are not required to perform analyses before signing the manifest. However, if during later analysis personnel discover a significant discrepancy, it must be reported to the Regional Administrator.

Step 14A Upon discovering a discrepancy, waste management personnel should attempt to reconcile the discrepancy with the generator as quickly as possible. If the discrepancy cannot be resolved in 15 days, additional reporting is required.

Step 14B If reconciliation cannot be made within 15 days after receipt of the waste, waste management personnel must submit a letter describing the discrepancy and attempts to reconcile it and a copy of the manifest or shipping paper to the EPA Regional Administrator.

Step $15 \quad$ Within 30 days of receipt of the manifested waste, waste management personnel must send a copy of the manifest to the generator. In addition, personnel must retain a copy of the manifest for at least three years from the date of delivery.

\section{REFERENCES FOR SUBMODULE 3.6}

1) PCB Manifesting, Tracking, and Reporting Requirements, US. Department of Energy, Office of Environmer tal Guidance, RCRA/CERCLA Division, Information Brief, EH-231-001/1190, November 1990.

2) 40 CFR 262 Subpart B -- Manifest requirements for generators.

3) 40 CFR 262.40 -- Recordkeeping.

4) 40 CFR 264 and 265 Subpart E -- Manifest system, recordkeeping, and reporting. 
Exhibit 3.6.1

Uniform Hazardous Waste Manifest

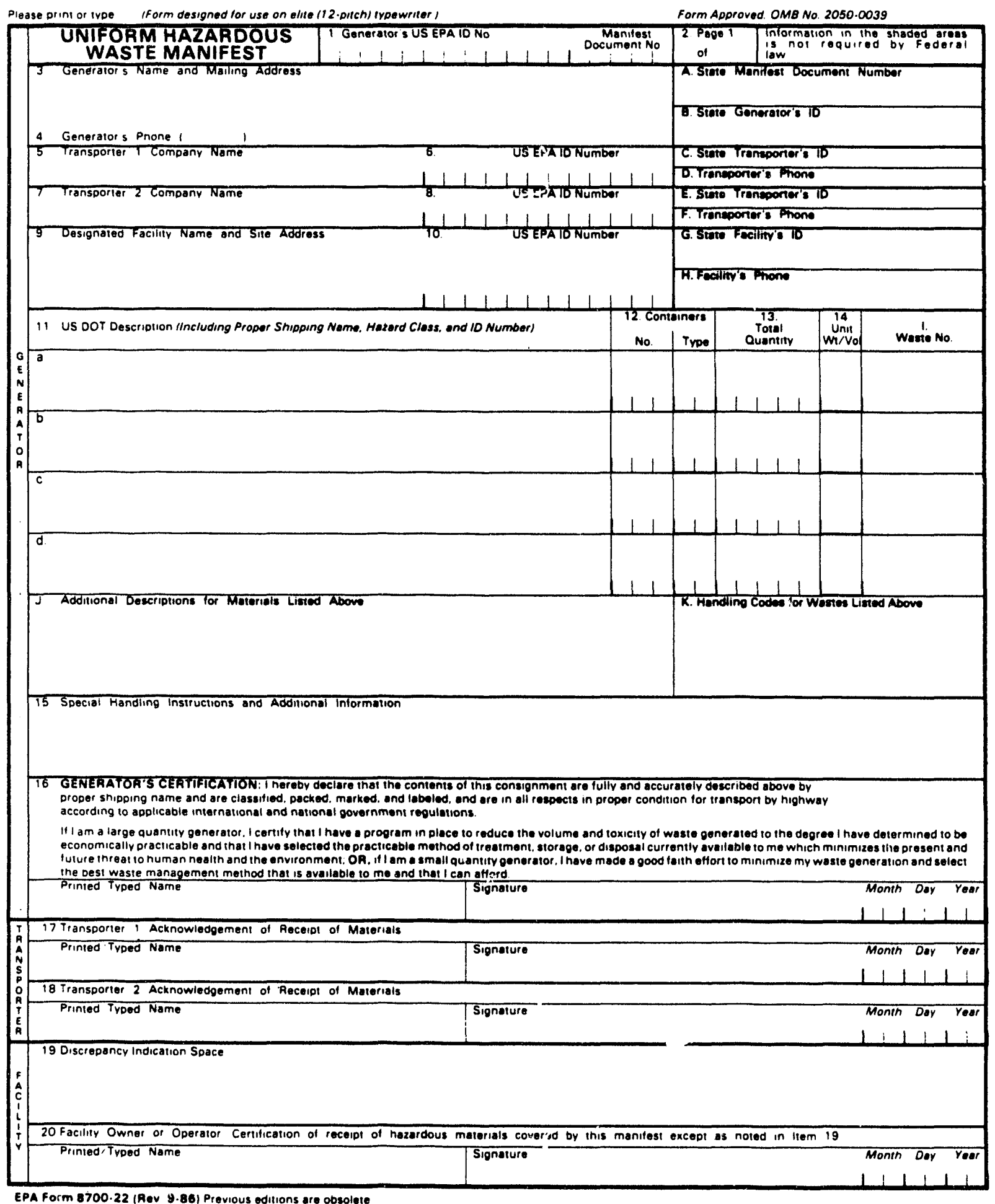

EPA Form 8700.22 (Rev 9.86) Previous editions are obsolete 


\section{Exhibit 3.6.1 \\ Uniform Hazardous Waste Manifest (cont.)}

Plaase print or type (form designed for use on elite (12.pitch) typewriter)

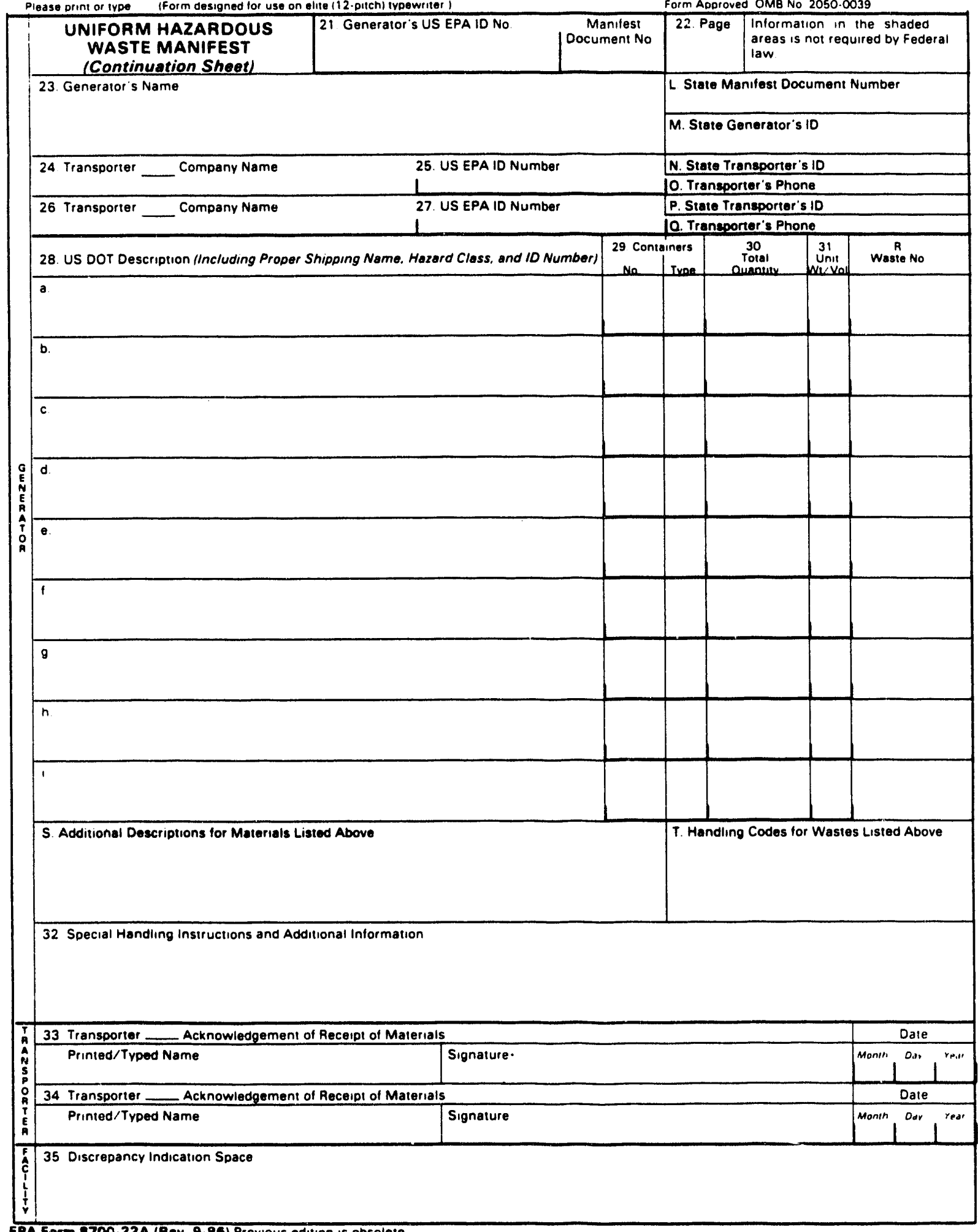

EPA Form 8700.22A (Rev. 9.86) Previous edition is obsolete 


\section{Module 3: Flowchart}

\section{SUBMODULE 3.7: LABELING AND MARKING}
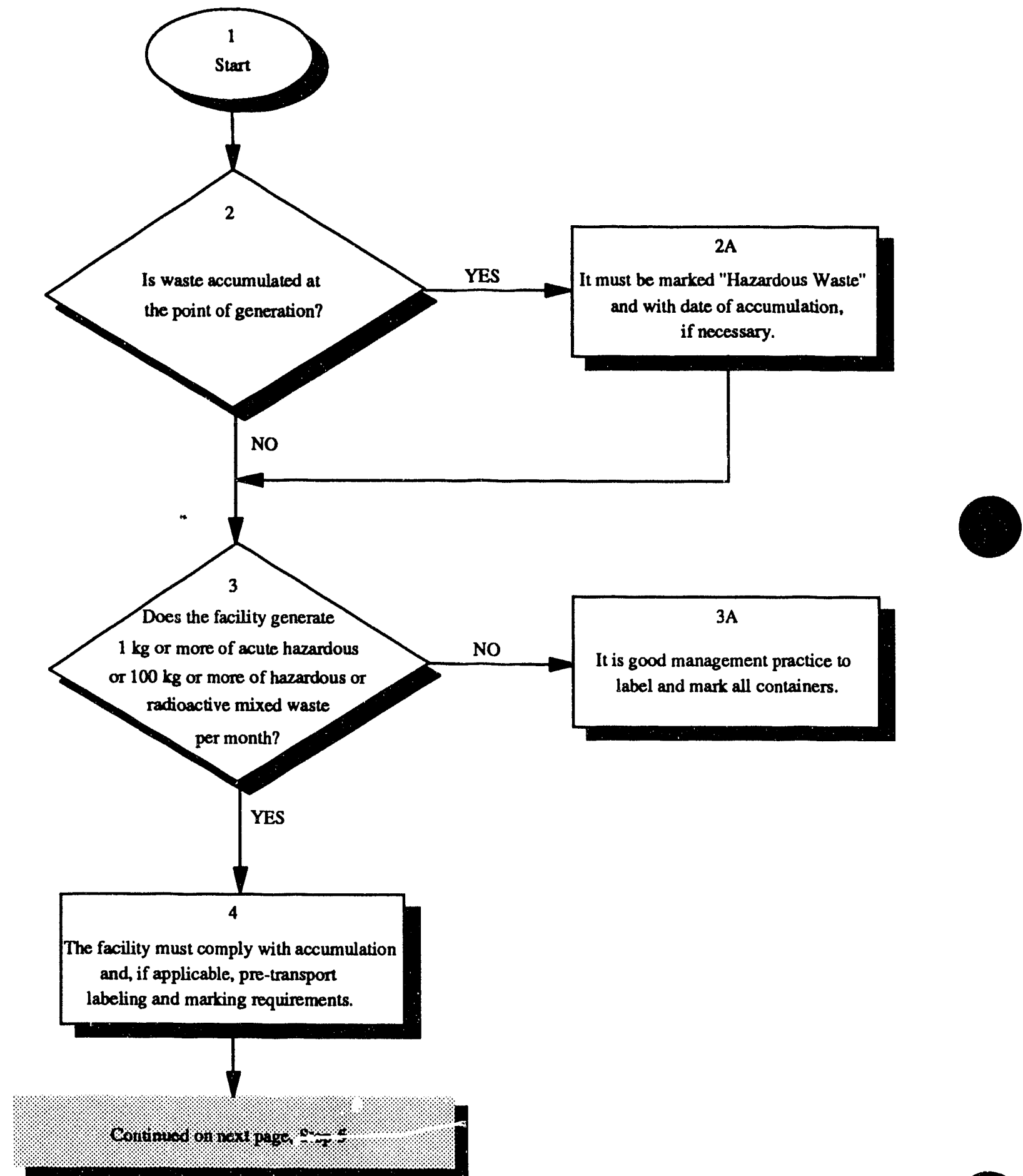


\section{SUBMODULE 3.7 LABEI.ING AND MARKING}

Step $1 \quad$ Start.

Step 2 Operating personnel may accumulate wastes in containers at the point of generation (up to 55 gallons of hazardous waste or one quart of acutely hazardous waste) without triggering the RCRA permitting or interim status storage requirements. These areas are termed satellite accumulation areas. Certain marking requirements apply to these areas (40 CFR 262.34 (c)(1) \& (c)(2)).

Step 2A The containers must be marked with the words "Hazardous Waste." If the waste accumulates in amounts in excess of those specified above, the containers holding the excess waste must be marked with the date the excess amount began accumulating. Module 1, "Applicability," (page 1-12) outlines additional requirements for facilities that exceed the 55 gallon limit.

Step 3 If a facility generates less than 1 kilogram of acutely hazardous or less than 100 kilograms of hazardous waste per month, the facility is defined as a "conditionally exempt small quantity generator."

Step 3A While RCRA does not require marking and labeling of conditionally exempt small quantity generator waste, it is good management practice to handle all hazardous waste in accordance with RCRA labeling and marking requirements, regardless of whether small quantity generator thresholds are exceeded.

Step 4 The facility must comply with RCRA accumulation labeling and marking requirements (40 CFR 262.34) and, when offered for off-site transport, RCRA pre-transport labeling and marking requirements (40 CFR 262.31 \& 262.32) and DOT requircments of 49 CFR Part 172. Labels are intended to allow for quick identification of the wastes in the containers and are therefore large in size and easy to read from a distance. Markings, on the other hand, describe in detail the name, instructions, cautions, and weights of the waste in the container. (Placarding requirements for transport vehicles are discussed in Submodule 3.8, "Transportation.")

In addition to the above requirements, the Department of Transportation has promulgated labeling and marking requirements for marine pollutants (57 FR 52930, November 5, 1992). The marking and labeling requirements for highway transportation of marine pollutants are found in 49 CFR 172.203 and 172.322. Marine pollutants have the potential to kill or retard growth of marine life and to bioaccumulate in marine organisms. A marine pollutant is a hazardous material which is listed in appendix B to 49 CFR Section 172.101, and when one or more marine pollutant is packaged in a concentration which equals or exceeds 1) ten percent by weight of the solution or mixture for materials listed in the appendix; or 2) one percent by weight of the solution or mixture for materials that are identified as severe marine pollutants in the appendix.

If the proper shipping name for a marine pollutant does not identify by name the component which makes the material a marine pollutant, the name of the component must appear in parentheses in association with the basic description [49 CFR 173.203]. Bulk packages containing marine pollutants must by marked on all four sides with the MARINE POLLUTANT mark as specified by DOT requirements in 49 CFR 172.322, unless they are placarded in accordance with the Hazardous Materials Regulations (HMR); [49 CFR 171-180]. The transport vehicle containing the marine pollutant must also be marked with the MARINE POLLUTANT mark which must appear on each side and each end of the transport vehicle. 


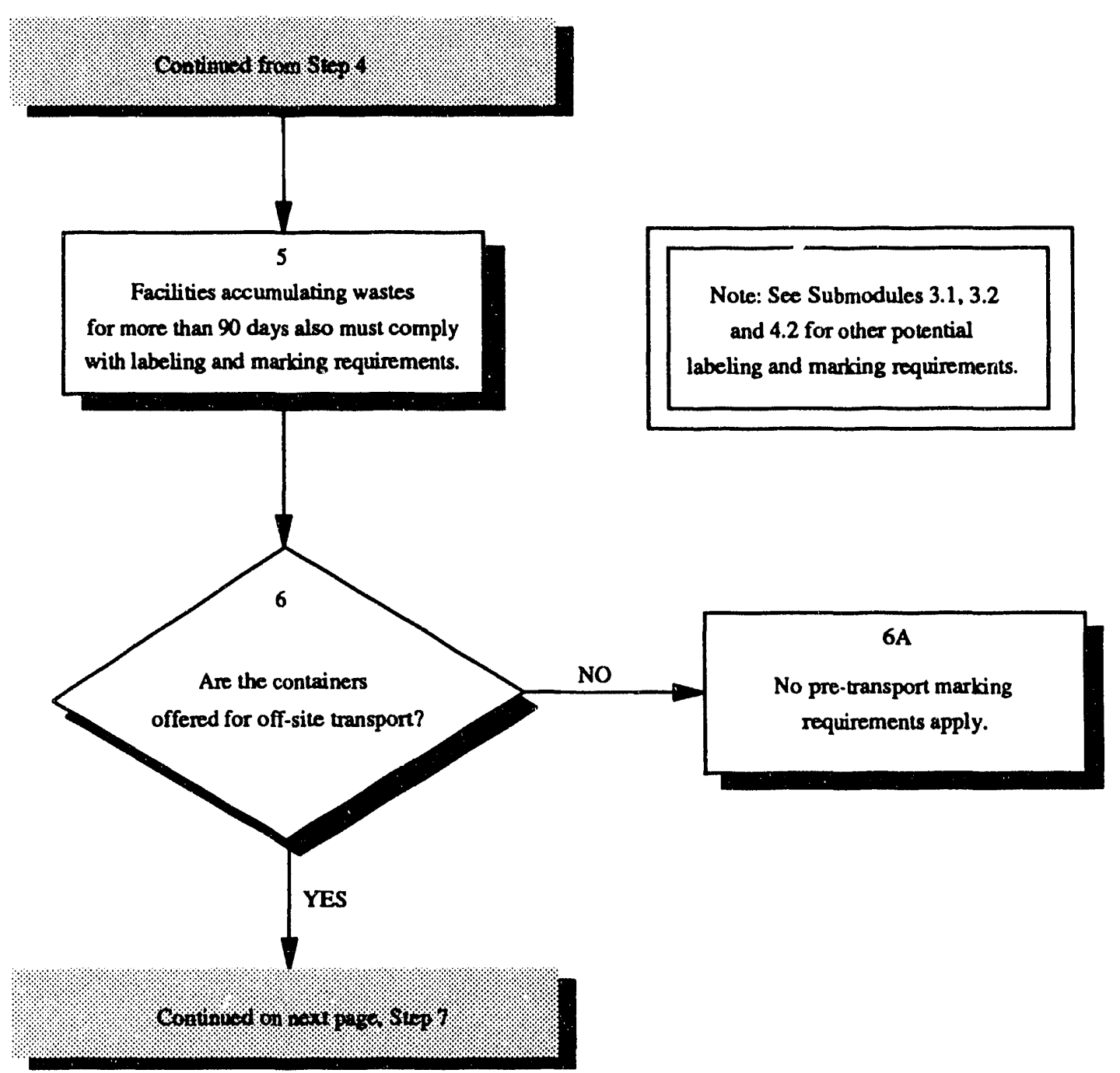


Facilities that accumulate hazardous waste for more than 90 days, without having been granted an extension by the Regional Administrator or State Director, are considered storage facilities and are subject to all applicable requirements of 40 CFR Parts 264 or 265. These facilities must comply with marking and labeling requirements that will have been specified in the permit. Labeling or marking requirements for interim status facilities storing wastes that are generated on-site are not explicitly established by regulation in 40 CFR 265; however, to operate an interim status container storage area prudently, waste management personnel should label and mark containers so they are easily identifiable and properly handled.

NOTE: See Submodule 3.1, "Waste Analysis"; Submodule 3.2, "Compatibility"; and Submodule 4.2, "Contingency Plans"; for additional container management requirements that may necessitate specific labeling and marking requirements.

Step 6 Prior to transporting hazardous waste off-site, waste management personnel must label and mark each container as specified by RCRA pre-transport labeling and marking requirements (40 CFR $262.31 \& 262.32$ ) and Department of Transportation regulations (49 CFR Part 172).

Step 6A Pre-transport marking requirements do not apply to containers not offered for off-site transport. 


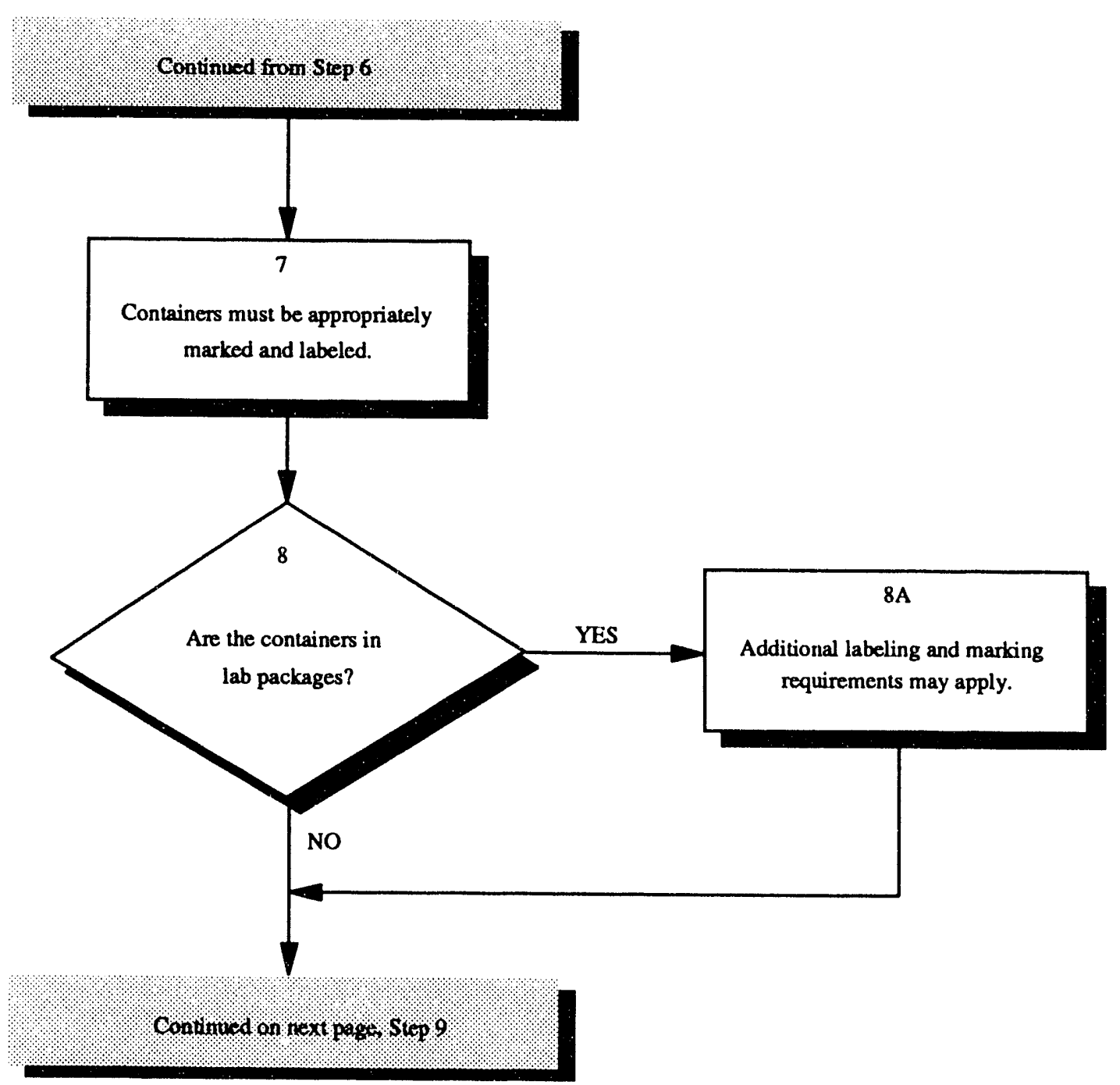


All containers holding a hazardous waste or radioactive mixed waste offered for transport must be labeled in accordance with RCRA requirements (40 CFR 262.31) and as specified by DOT requirements ( $49 \mathrm{CFR} 172.101$ or 172.102 ). Waste management personnel should consult the tables in those sections and label the containers as directed. Additional requairements are located in 49 CFR $172.400-172.406$.

Labels must be affixed to the surface of the container near the marked proper shipping name. However, labels may be fixed by other suitable means (e.g., tag) to (1) a container that is smaller than the required label if it contains no radioactive waste, (2) a compressed gas cylinder, or (3) a container has such an irregular surface that a label cannot be satisfactorily affixed. Labels must not be obscured by markings or attachments. All labels must be attached to a background of contrasting color or must have a dotted or solid line outer border. If two or more labels are required, they must be displayed or affixed next to each other. If a container has a volume of 64 cubic feet or more, labels must be displayed on at least two sides or ends of the container.

Containers must be marked in accordance with 40 CFR 262.32 and as specified in 49 CFR 172.300. All markings must be durable; written in English; affixed to the surface of the container on a tag, or on a sign; displayed on a background of sharply contrasting color; unobscured by labels or attachments; and located away from other markings that could substantially reduce their effectiveness. Each container of 110 gallons or less must be marked with the following words:

"HAZARDOUS WASTE--Federal Law Prohibits Improper Disposal. If found, contact the nearest police or public safety authority or the U.S. Environmental Protection Agency. Generators Name and Address Manifest Document Number

Examples of the proper labels and markings are included at the end of this submodule.

Step 8

Step 8A

A lab package is defined as any container that holds smaller containers of hazardous waste. A lab pack need not contain laboratory wastes per se.

Lab packs must be packed with closures upward and must be marked "THIS SIDE UP" or "THIS END UP," as appropriate. Lab packs must also be marked with an arrow symbol as specified in ANSI MH6.11968. Labeling requirements for lab packs are found in 49 CFR 172.404(a). In general, the outside of a lab pack must be labeled to comply with the requirements for all the materials contained in the lab pack (i.e., lab packs with multiple wastes must be marked and labeled to describe all of the wastes contained in the lab pack). See also 49 CFR 173.12. 


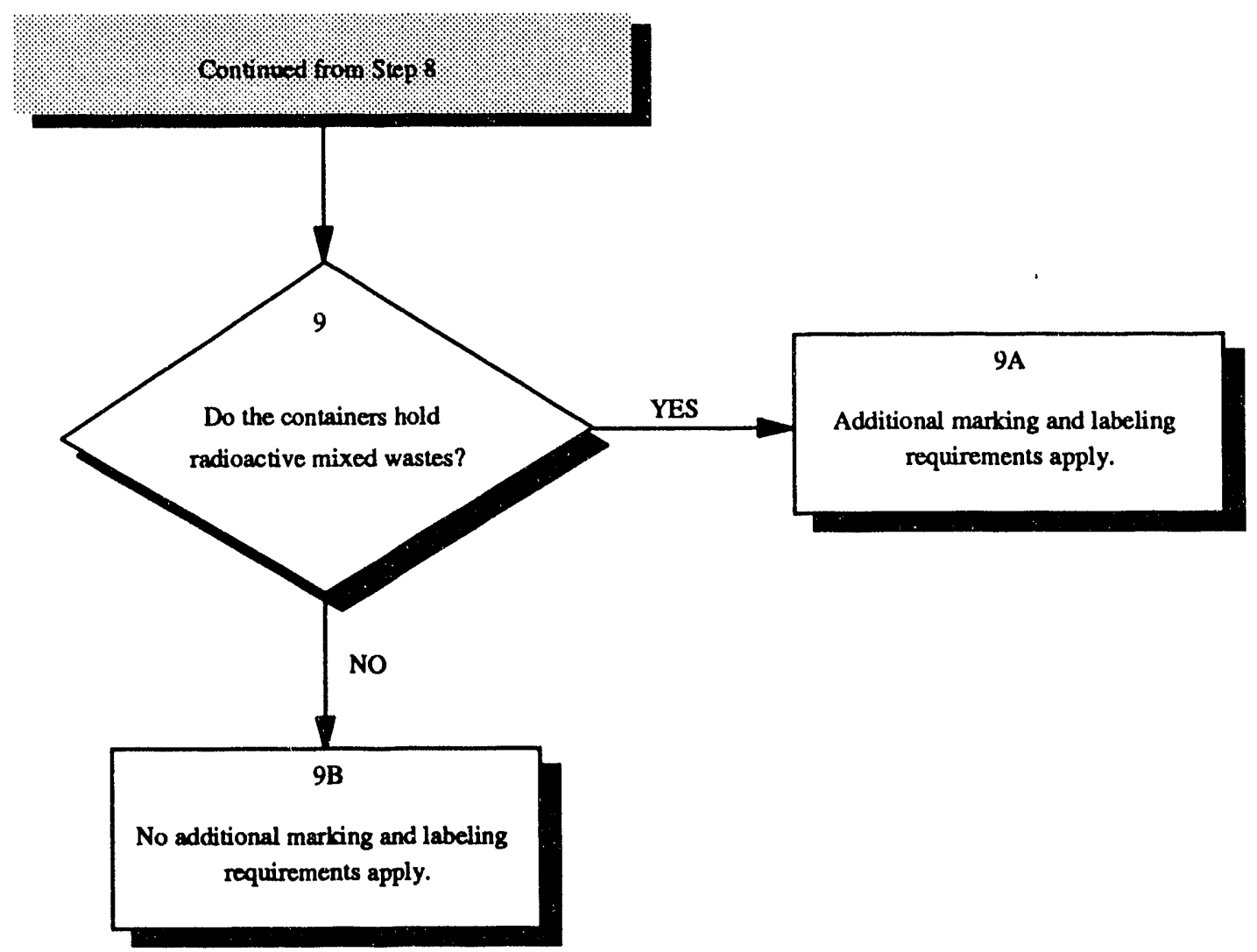


Step 9A Containers holding radioactive mixed waste that are to be offered for transport must comply with DOT marking and labeling requirements for radioactive materials to the extent applicable. DOT labeling requirements for radioacive materials are located in 49 CFR 172.403 and are based on the radiation level at the surface of the container, the DOT "transport index" as defined in 49 CFR 173.403, and the fissile characteristics of the package. DOE marking requirements for radioactive material are located in $49 \mathrm{CFR}$ 172.403 and are based on the size of the container and the type of radioactive material.

Step 9B No additional marking and labeling requirements apply.

\section{REFERENCES FOR SUBMODULE 3.7}

1) RCRA Hazardous Waste Container Labeting Marking, and Placarding Requirements, U. S. Department of Energy, Office of Environmental Guidance, RCRAVCERCLA Division, Information Brief, EH-231-031/0793, Juty 1993.

2) 40 CFR 262.31 - Labeling

3) 40 CFR 262,32 - Marking.

4) $40 \mathrm{CFR} 262.33$ - placarding

5) 40 CFR 262,34 - Accumulation time.

6) 49 CFR Part 172 - Hazardous materials table.

7) ANSI MH6.11968. 
Exhibit 3.7.1

Examples of Proper Labels
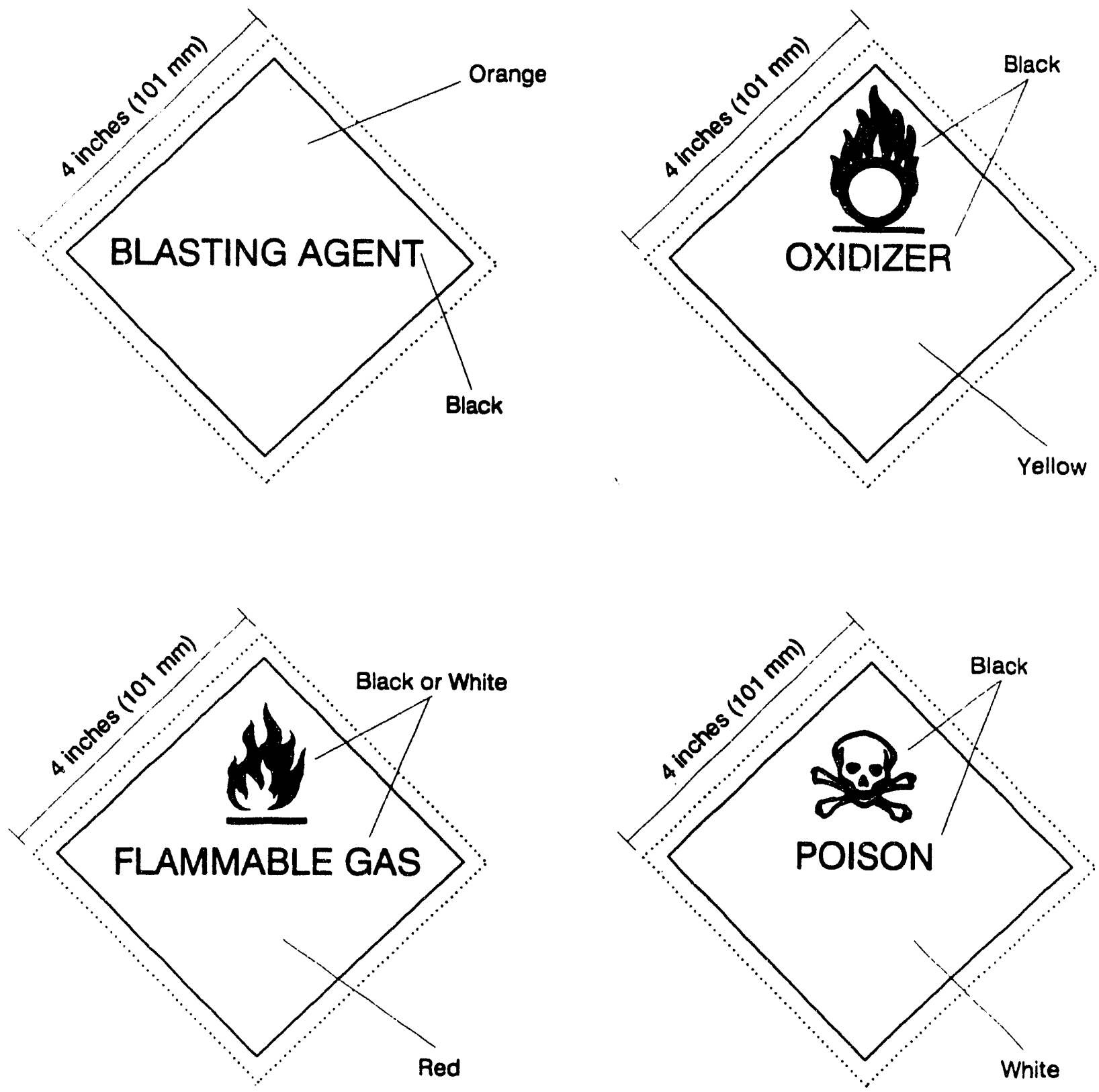
Exhibit 3.7.2

Examples of Proper Markings

\section{HAZARDOUS WASTE} FEDERAL LAW PROHIBITS IMPROPER DISPOSAL IF FOUND, CONTACT THE NEAREST POLICE OR PUBLIC SAFETY AUTHORITY OR THE U.S. ENVIRONMENTAL PROTECTION AGENCY

GENERATOTrS MAME

ADORESS

EPNDOT

SHIPPINO NAME

CONSYITUENTS

Hazapo

cuas.

AHEY HANDUMG OR DURING ROUTIME OR ENEAGEMCY EXPOSUAE TO THE MUA ChETKED BEL OW

0 mard hat

0 8droty Claneen

口 Senty expin

o fun foces Enim

- Promine Clon

口 Solmon Aaros

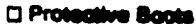

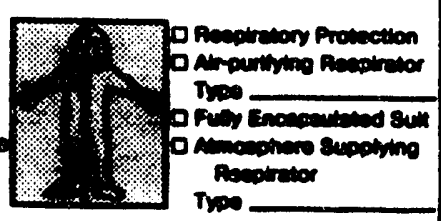

Tros
EPA :

arr

STATE

EPA waste

- 1984 HAZARDOUS MATERIALS PUBLISHING CO. • 215.683-6721 • KUTZTOWN. PA 19530 


\section{Module 3: Flowchart}

\section{SUBMODULE 3.8: TRANSPORTATION}

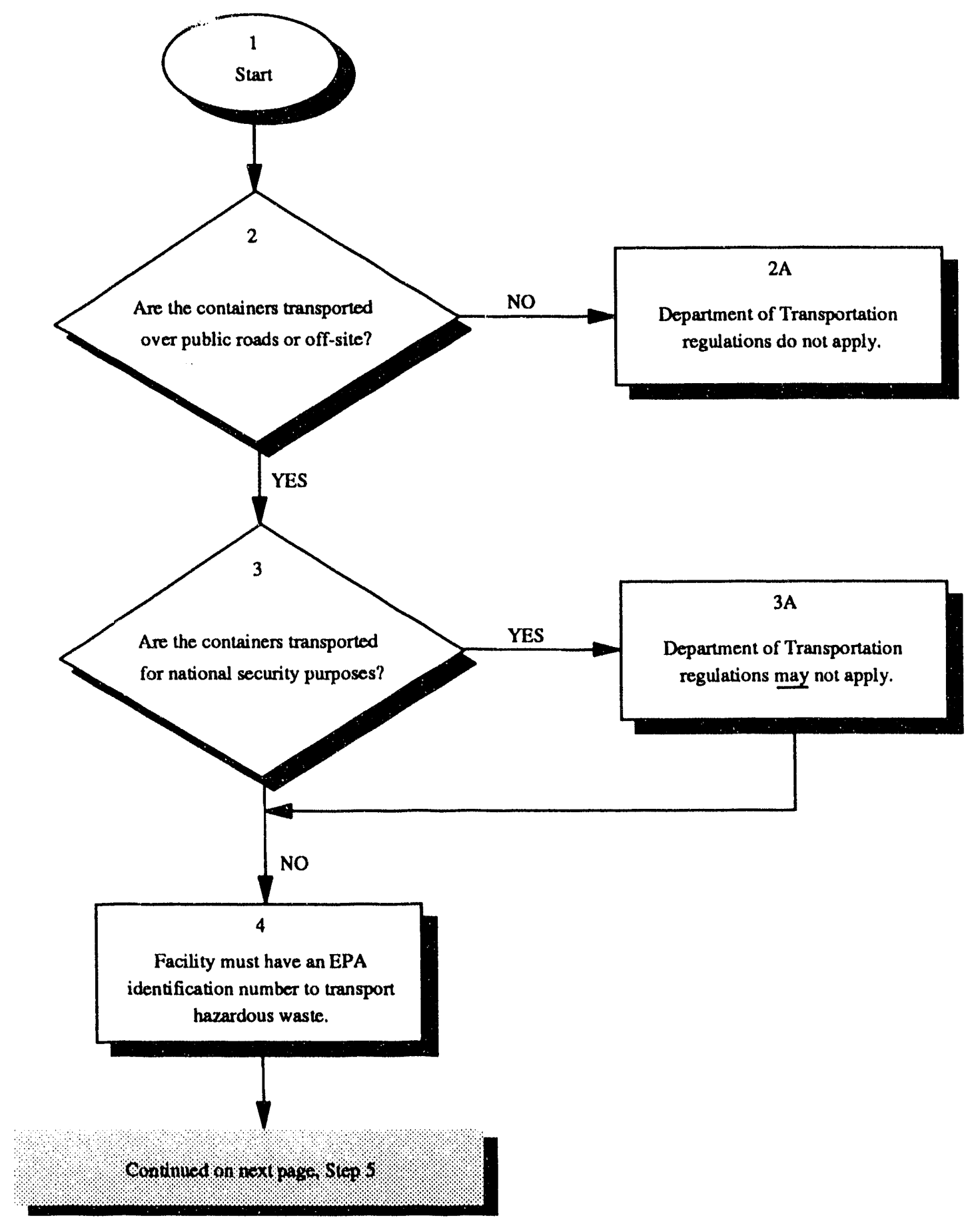


Step 1

Step 2

\section{Step 2A}

Step 3

Step 3A

Step 4
Start.

Hazardous waste in containers is subject to Department of Transportation regulations and RCRA transportation regulations when the waste is transported outside of DOE property or on a public road. A "public road" should be interpreted to mean any motor vehicle right of way open to unrestricted public access. Additionally, it is good management practice to use DOT-approved containers and placards when transporting hazardous wastes solely on DOE property, if it is likely that significant vehicular traffic will be encountered.

If the hazardous waste containers are transported only within a facility, transportation regulations do not apply.

Questions regarding the national security exemption from transportation requirements for specific DOE shipments should be referred to DP-1 for resolution at the Headquarters level.

Shipments of hazardous waste made by or for DOE for the purpose of national security, which are escorted by designated waste inanagement personnel, may be exempted from the regulations of 49 CFR Parts 171 through 178, on a case-by-case basis.

Before transporting a waste, the facility must obtain an EPA identification number from the Regional Administrator (40 CFR 263.11). An EPA identification number may be obtained by completing EPA form 8700-12 if one has not already been obtained. 


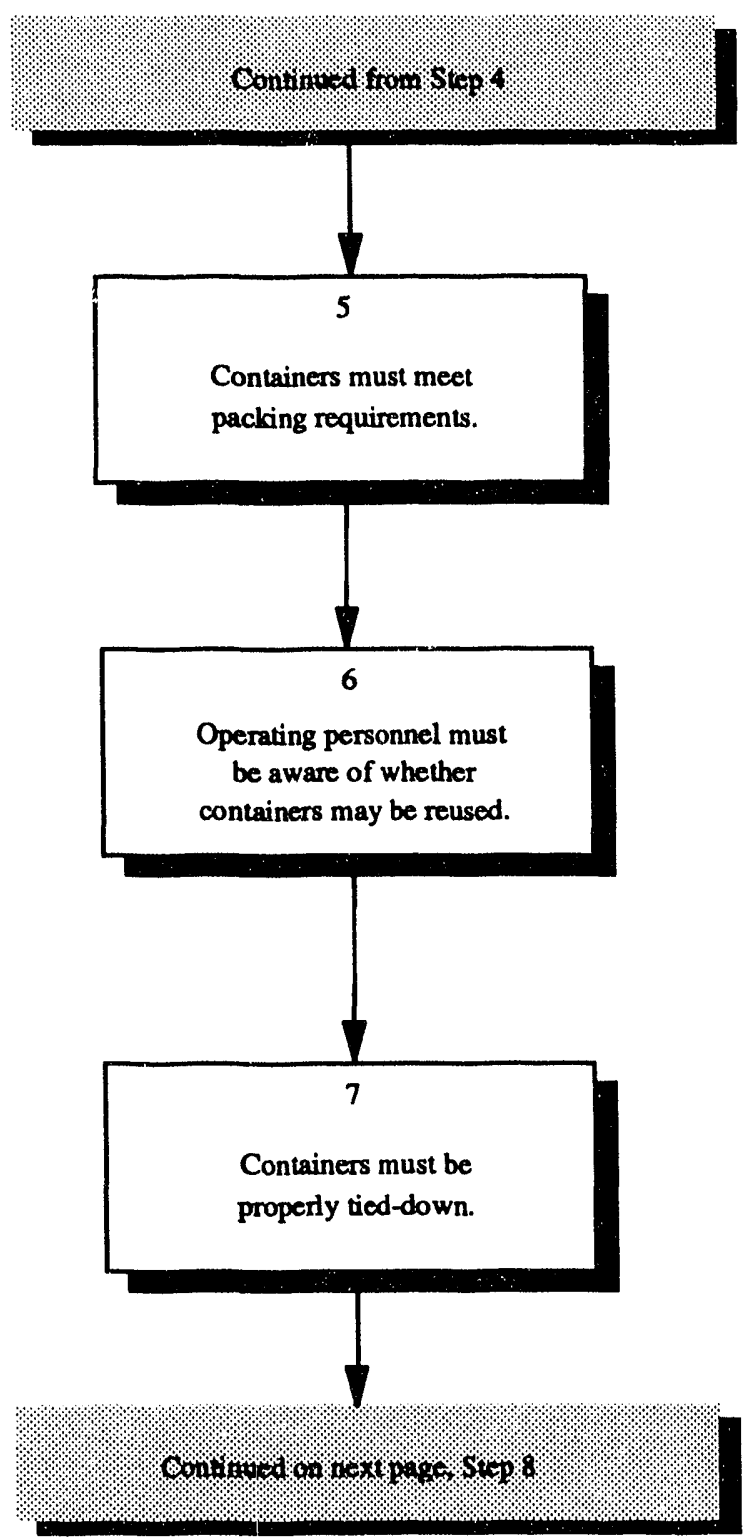


Department of Transportation regulations (40 CFR Parts 173,178 , and 179) specify the types of containers and proper construction for containers to be used to transport hazardous waste. In general, 40 CFR Part 173 specifies the types of containers acceptable for different kinds of hazardous waste, while Parts 178 and 179 specify the proper construction of the containers. When shipping hazardous waste in containers, operating personnel also are responsible for ensuring that the hazardous waste is labeled and marked in accordance with 49 CFR Part 172. See Submodule 3.7, "Labeling and Marking," for a discussion of labeling and marking requirements.

All containers used for transportation must be constructed so that under conditions normally incident to transportation: (1) there will be no significant release of the hazardous materials to the environment; (2) the effectiveness of the container will not be substantially reduced; and (3) there will be no mixture of gases or vapors in the container which could significantly reduce the effectiveness of the container.

Step 6 Operating personnel should be aware that any containers labeled as single trip or nonreusable may only be used once to ship hazardous waste. Operating personnel may re-use containers for transportation provided that the container meets all the requirements for new containers of the same type. Old markings must be thoroughly removed and new markings and labels must be easily readable. A metal plate with the necessary markings on it may be securely fastened to the container if necessary.

Step 7 In tying down hazardous waste containers, operating personnel should only use materials with a strength rating established and documented by the manufacturer. The following should not be used as components of a tiedown system (DOE Order 1540.1 Materials Transportation and Traffic Management):

- plastic or fiber rope;

- $\quad$ any material with unknown strength; and

- $\quad$ any damaged material.

Waste management personnel should use materials with elastic properties if possible. For example, wire rope is preferable to chain because it is more flexible and therefore better able to withstand the stresses of transportation.

The principal tiedown forces should be transmitted to the vehicle frame. In addition, the strength of the tiedown points should be greater than or equal to the strength of the tiedowns themselves. Operating personnel should ensure that the tiedown assemblies are free from contact with stationary objects; that the tiedowns are not kinking, crimping, or splaying; and that the tiedowns will not loosen during transportation. The tiedowns should not be exposed to dirt, weather extremes, rain, or corrosives, which may reduce the effectiveness of the tiedowns. Finally, it is the responsibility of waste management personnel to ensure that the tiedowns are inspected regularly and that the tiedowns are tightened when necessary. 


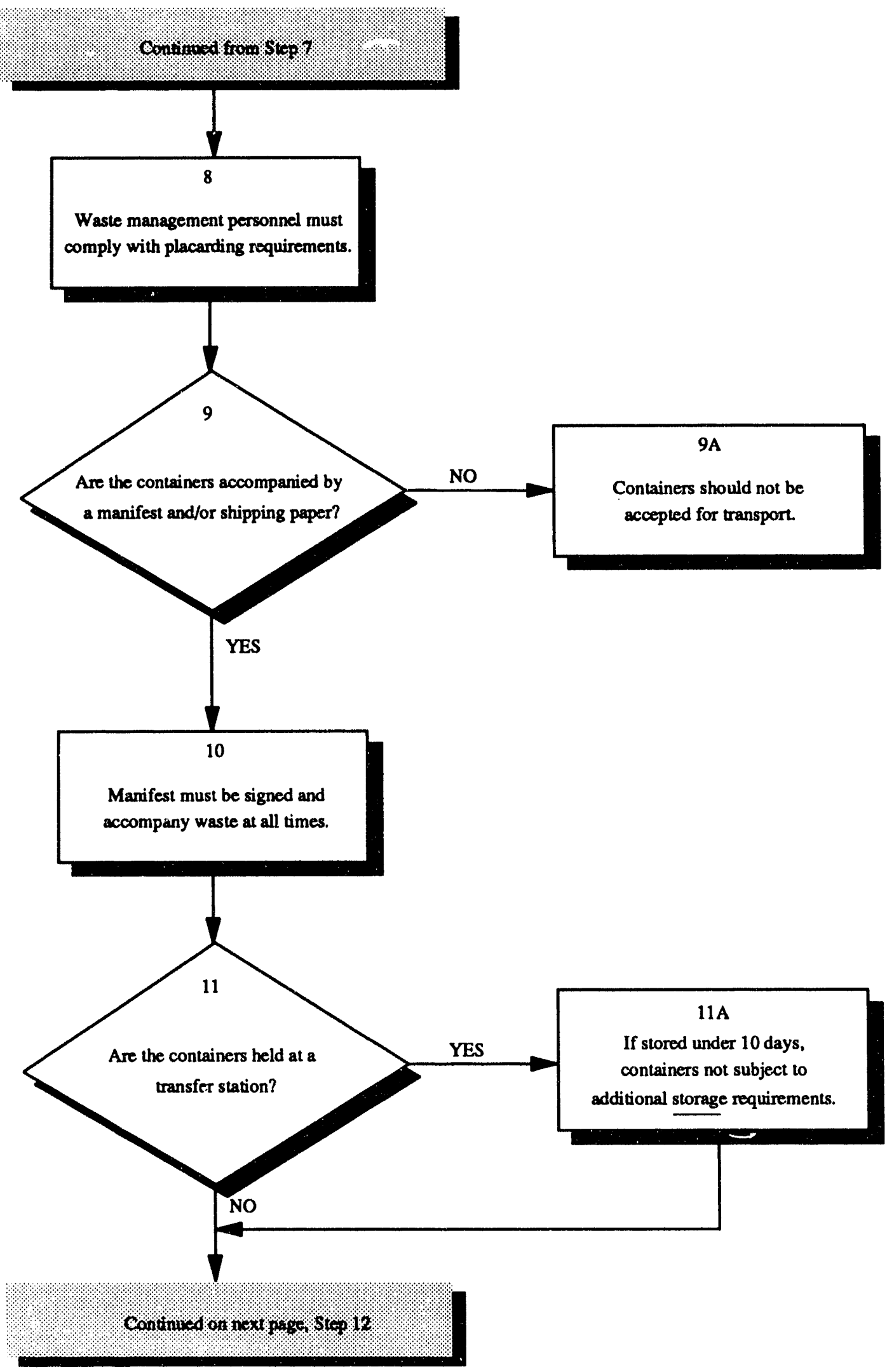

Module 3 
Each transport vehicle and freight container transporting hazardous waste must comply with placarding requirements. If a commercial carrier is transporting hazardous waste, waste management personnel must provide the transporter with the appropriate placards. Tables 1 and 2 of Subpart F of 49 CFR Part 172 specify the types of placards required for different substances. Waste management personnel must also be aware of specific requirements for materials posing an inhalation hazard, materials which are only residues, and vehicles which have been fumigated (49 CFR Part 172, Subpart F).

Placards must be readily visible, must be securely attached to the vehicle, may not be placed next to any marking that may reduce their effectiveness, and should not be placed so that water or dirt from the wheels of the vehicle are directed at the placard. Placards must be displayed horizontally so that words can be read from left to right. All placards must meet the regulations of 49 CFR $172.519-172.558$. These regulations specify the proper construction, size, and wording of the placards. In addition, Appendix C of 49 CFR Part 172 contains specifications for placard holders. Placards are not required for (1) a transport vehicle or freight container holding less than 1,000 pounds aggregate gross weight of hazardous material, as long as those materials are not required to meet the poison-inhalation hazard shipping paper requirements; and (2) a rail car loaded with transport vehicles or freight containers, none of which needs to be placarded.

Step 9 When transporting hazardous waste in containers, waste management personnel must comply with the manifesting requirements of Subpart B of 40 CFR Part 263, unless specifically exempted (see Submodule 3.6, "Manifesting and Recordkeeping").

DOT requirements specify that all hazardous waste transported must be accompanied by a shipping paper (49 CFR 172.200); however, a properly completed manifest will serve in lieu of a shipping paper. If the manifest has not been received by the facility or transporter receiving the waste, waste management personnel must obtain the date of delivery and handwritten signature of the receiver of the waste from the DOT shipping paper, if available (see Step 13). General DOT shipping paper requirements are specified in 49 CFR 172 Subpart C.

Step 9A Transporters may not accept hazardous waste containers from a generator unless they are accompanied by a properly signed and completed manifest. In some cases (i.e., when shipping waste to the designated facility by water or for shipments involving rail transport), the shipping paper may serve in lieu of the manifest (40 CFR 263.20).

Step 10 Before transporting the waste, waste management personnel must sign and date the manifest to acknowledge acceptance of the waste from the DOE facility that generated the waste. A signed copy of the manifest must then be returned to the originating facility before the waste leaves the property. During transportation, the manifest must accompany the hazardous waste at all times. When the waste is delivered, either to another transporter or to the receiving facility, waste management personnel must obtain a handwritten signature and date on the manifest. One copy of this signed manifest should be retained by the transporter and the remaining copies should be given to the receiver of the waste.

Step 11 A transfer station is any transportation-related facility, including loading docks, parking areas, storage areas, and other similar areas where shipments of hazardous waste are held during the normal course of transportation.

Step 11A If DOE stores manifested shipments of hazardous waste in containers at a transfer facility for less than 10 days, then the storage of those wastes are not subject to regulation under 40 CFR Parts 264, 265, 268, and 270. Transportation requirements still apply. 


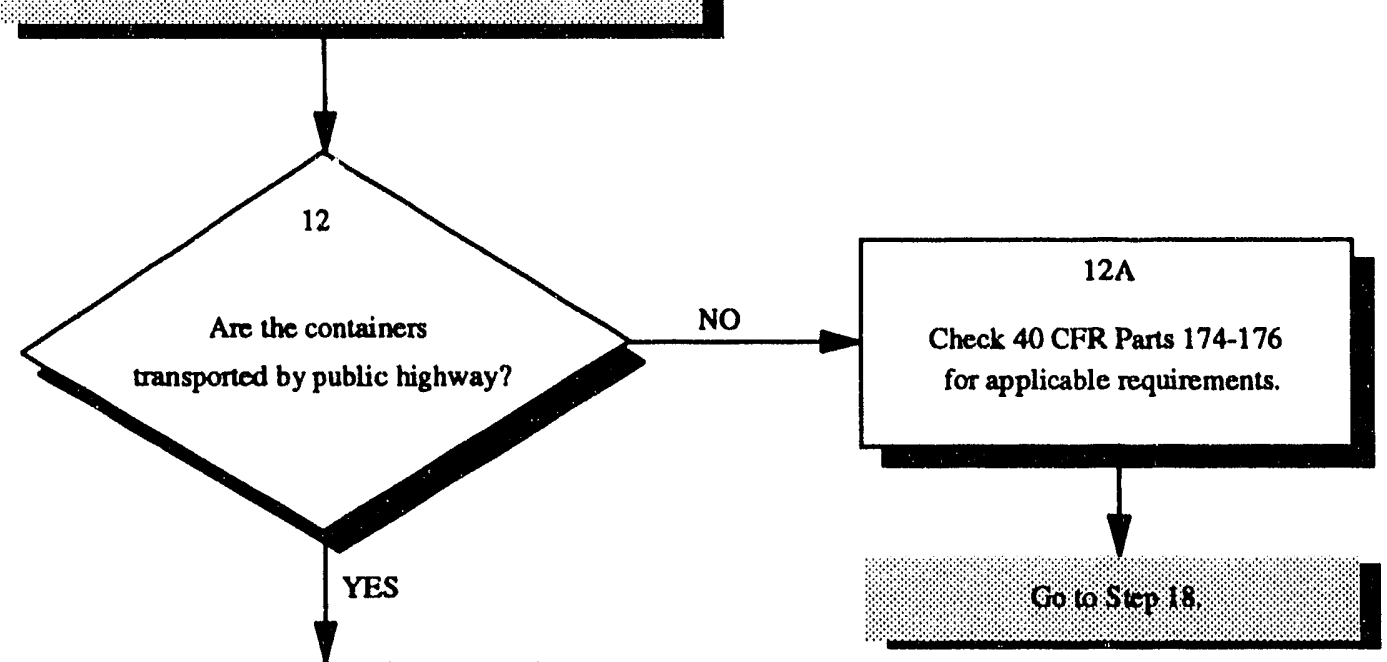

13

Containers must be accompanied by shipping papers.

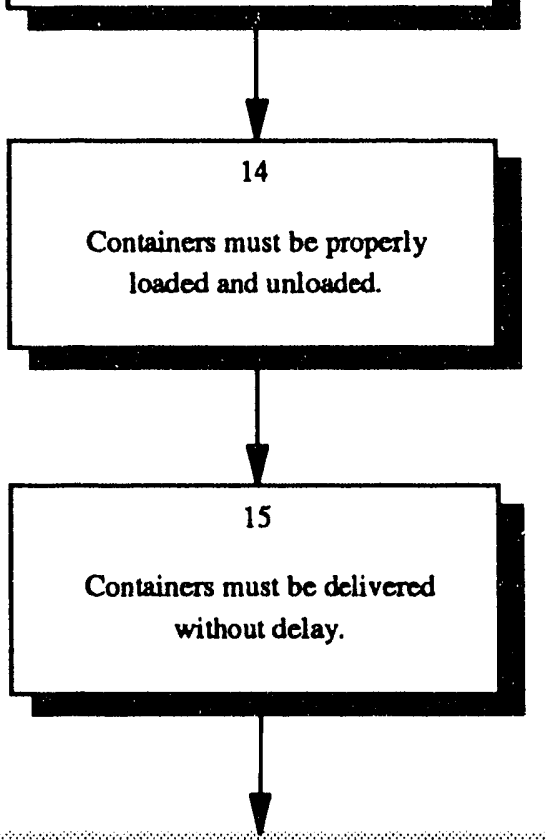

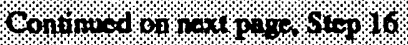


Specific requirements apply to the transportation of hazardous wastes on public roads.

Step 12A

49 CFR Parts 174 and 176 detail specific requirements for rail and vessel (i.e., water) transportation. Hazardous waste is forbidden from air transport. When DOE transports a container by rail or vessel, the appropriate regulations should be consulted for additional requirements. In addition, waste management personnel should consult Step 18 within this submodule for additional requirements if there is a hazardous waste incident (i.e., a spili).

Step 13 All shipments of hazardous waste by public highway must be accompanied by a DOT shipping paper. However, a hazardous waste manifest containing all the required shipping paper information may be used as a shipping paper (49 CFR 172.205(h)). The driver of the motor vehicle must ensure that the DOT shipping paper is readily available and identifiable by authorities in the event of an accident or hazardous waste incident. The DOT shipping paper must be clearly distinguished if it is carried with other papers. When the driver is in the vehicle, the DOT shipping paper must be stored so that it is in his immediate reach and either readily visible or in a holder mounted on the inside of the driver's door. When the driver is not in the vehicle, the DOT shipping paper must either be in a holder mounted on the inside of the driver's door or on the driver's seat. 49 CFR Part 177 details specific requirements of carriage of hazardous waste by public highway.

Step 14 All containers must be secured using blocking and bracing techniques against movement within the vehicle on which they are being transported (DOE Order 1540.1 Materials Transportation and Traffic Management). Hazardous materials may not be transported on pole trailers. During the loading of the containers, the handbrake must be set, and other precautions (e.g., blocking of wheels), if necessary, should be taken to ensure that the truck does not move during loading. Waste management personnel must not use any loading tools that may damage containers. Waste management personnel must oversee loading and unloading operations. In addition, waste management personnel must not load hazardous wastes together if such loading is prohibited in the loading and storage chart of 49 CFR 177.848. Waste management personnel should also be aware that vehicles with cargo heaters may only be used to transport hazardous wastes if specific requirements (specified in $49 \mathrm{CFR} 177.834(1)$ ) are met. In addition to these general loading and unloading requirements, there are specific requirements for the following types of waste: (1) explosives, (2) flammable liquids, (3) flammable solids and oxidizing materials, (4) corrosive liquids, (5) compressed gases, (6) poisons, and (7) radioactive materials. Waste management personnel should consult the appropriate regulations (specified in 49 CFR 177.835 - 177.844) to determine additional requirements.

Step 15 Waste management personnel must transport hazardous materials without unnecessary delay to a facility authorized to receive such wastes. During transportation, records, equipment, and containers must be made available to DOT for inspection and examination. In addition, waste management personnel must comply with all State regulations regarding the transport of hazardous waste through tunnels. Waste management personnel must also maintain an adequate supply of labels and placards so that any missing or unreadable labels or placards may be replaced during transport. 


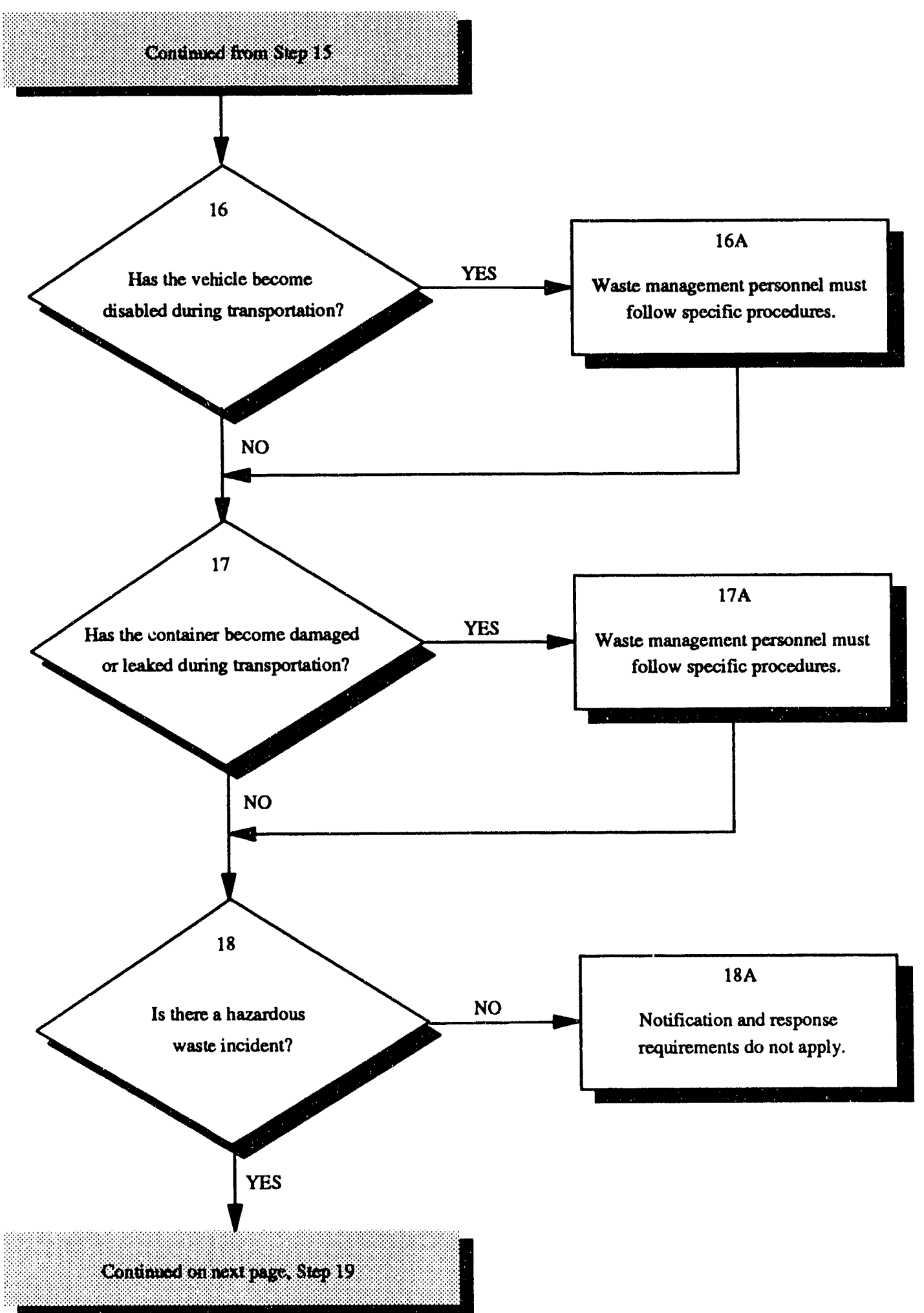


Step 16

Step 16A

Step 17

Step 17A

Step 18

Step 18A
Waste management personnel must follow specific requirements if a vehicle carrying containers of hazardous waste becomes disabled.

If a truck carrying hazardous waste becomes disabled, special care should be taken to remove the vehicle to an area where the load is sufficiently protected from dangers. If necessary, warning devices should be used. The repair and maintenance of vehicles containing hazardous waste is also regulated. No repairs may be made inside a building unless: the cargo area is closed and there is no leakage from the containers; the vehicle can be easily removed in case of an emergency; and the vehicle is removed from the building upon completion of repair or maintenance work. In addition, no repairs should be made with an open flane on a motor vehicle placarded as combustible or on any other vehicle if explosive gases are present in the compartment holding the wastes.

Specific requirements must be followed if containers are damaged or leak during transportation.

If containers are found to be damaged or leaking during transportation, the most practicable of the following three steps should be taken: (1) the container may be repaired and transported to the nearest acceptable disposal place; (2) the hazardous waste may be forwarded to the destination or returned to the shipper using a salvage drum; or (3) the waste may be stored pending proper disposition in the safest and most expeditious manner. In addition to these general incident requirements, the regulations specify action that should be taken during accidents with the following types of waste: (1) explosives,

(2) flammable liquids, (3) flammable solids and oxidizing materials, (4) corrosive liquids, (5) compressed gases, (6) poisons, and (7) radioactive materials. Waste management personnel should consult the appropriate regulations (49 CFR $177.855-177.861$ ) to determine additional requirements.

At the earliest practicable moment, waste management personnel must notify the Department of Transportation when an incident occurs during the course of transportation (including loading, unloading, and temporary storage) that causes one of the following: (1) a person is killed; (2) a person receives injuries requiring hospitalization; (3) property damage exceeds $\$ 50,000$; (4) the general public is evacuated for one or more hours; (5) one or more major transportation arteries or facilities are shut down for one hour or more; (6) the operational flight pattern or routing of an aircraft is altered; (7) fire, breakage, spillage, or suspected radioactive contamination occurs involving shipment of radioactive material; (8) fire, breakage, spillage, or suspected contamination occurs involving shipment of etiological materials; or (9) a situation exists that, in the judgement of DOE, should be reported to DOT even though it doesn't meet any of the previous criteria.

If none of the criteria outlined in Step 18 are met, then notification and response requirements do not apply. 


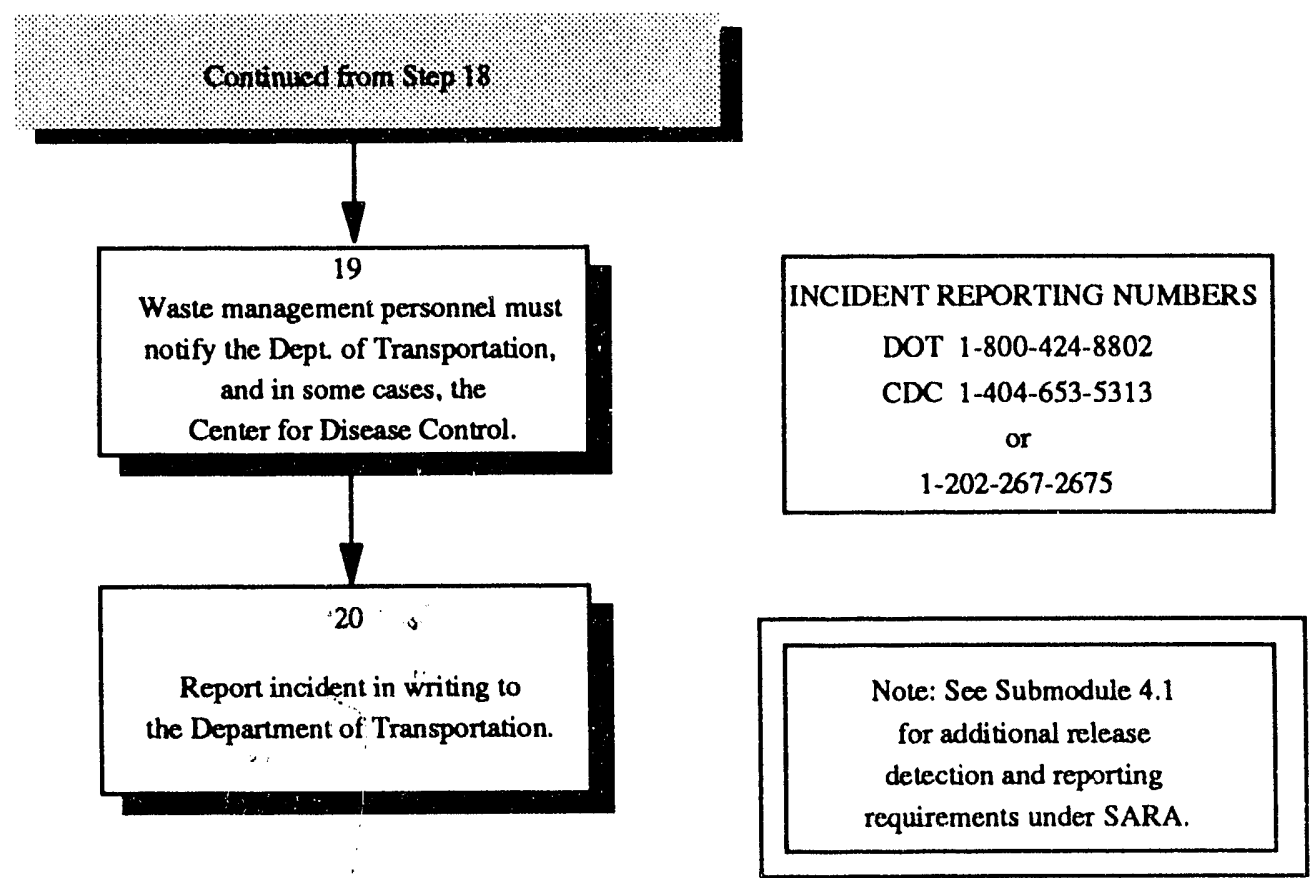


Notice should be given to DOT at (800) 424-8802. Notice involving etiological agents may be reported to the Center for Disease Control at either (404) 633-5313 or (202) 2672675. The notice must include the following information:

- name of reporter;

- $\quad$ name and address of carrier;

- $\quad$ phone number where reporter can be contacted;

- date, time, and location of incident;

- the extent of injuries;

- $\quad$ classification, name, and quantity of hazardous waste involved; and

- type of incident and nature of hazardous waste involvement.

Step 20

Within 30 days of the incident, waste management personnel must report the incident in writing, in duplicate, on DOT Form F 5800.1. If the report pertains to a hazardous waste discharge, waste management personnel must attach a copy of the hazardous waste manifest to the form. In addition, an estimate of the quantity of the waste removed from the scene, the name and address of the facility to which the waste was taken, and the manner of disposition of any removed waste must be indicated in Section IX of the form. The report should be sent to the Information Systems Manager, DHM-63, Research and Special Programs Administration, Department of Transportation, Washington, D.C., 20590-0001. Waste management personnel must retain a copy of the report for two years at the principal place of business of the carrier. If DOT investigates the incident, waste management personnel are required to provide reasonable assistance, including providing access tc all records pertaining to the incident.

NOTE: Reporting requirements under the Emergency Planning and Community Right to Know Act (EPCRA) under SARA may also apply. See Submodule 4.1, "Release Detection and Reporting," for more information. 


\section{REFERENCES FOR SUBMODULE 3.8}

1) Conduct of Operations Requirements for DOE Facilities, U.S. Department of Energy, DOE Order 5480.19, July 7, 1990.

2) Emergency Response Guidebook, U.S. Department of Transportation, Office of Hazardous Materials Transportation, September 1987.

3) Materials Transportation and Traffic Management, U.S. Department of Energy, DOE Order 1540.1, May 1982.

4) Safety Requirements for the Packaging and Transportation of Hazardous Materials, Hazardous Substances, and Hazardous Wastes, U.S. Department of Energy, DOE Order 5480.3, July 9, 1985.

5) 40 CFR Part 263 .. Standards applicable to transporters of hazardous waste.

6) 49 CFR Part 171 .- General information, regulations, and definitions.

7) 49 CFR Part 172 -- Hazardous materials table.

8) 49 CFR Part 173 -- General requirements for shipments and packagings.

9) 49 CFR Part 178 -- Specifications for packagings.

10) 49 CFR Part 179 -. Specification for tank cars. 


\section{MODULE 4}

\section{EMERGENCY PREPAREDNESS, RESPONSE, AND REMEDIATION}

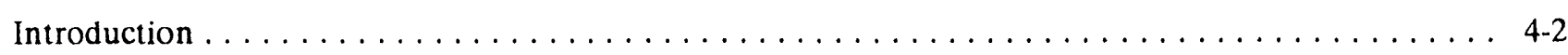

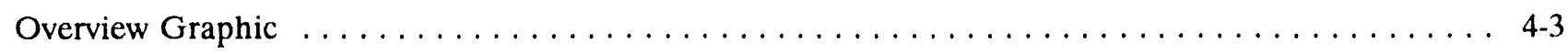

Submodule 4.1 - Release Detection and Reporting $\ldots \ldots \ldots \ldots \ldots \ldots \ldots \ldots \ldots \ldots \ldots \ldots$

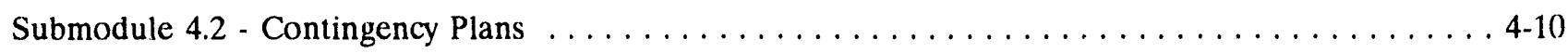

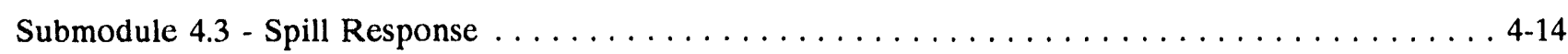

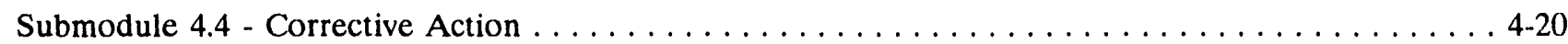


Introduction to Module 4: Emergency Preparedness, Response, and Remediation

This module provides guidance on preparing for spills and other emergencies at container storage areas and responding to such emergencies when they occur. Waste management personnel should use this module to:

- identify technical guidance that will allow them to conduct inventories of hazardous and toxic chemicals and comply with release reporting requirements that may apply to these chemicals;

- $\quad$ prepare contingency plans containing the necessary elements to enable waste management personnel to prepare for emergencies that may occur;

- $\quad$ respond to spills; and

- comply with corrective action requirements and identify detailed technical guidance on the various components of the corrective action process.

The following flowchart and accompanying narrative discussion guides you step-by-step through the applicable requirements for container storage areas. 


\section{OVERVIEW OF MODULE 4: EMERGENCY PREPAREDNESS, RESPONSE, AND REMEDIATION}

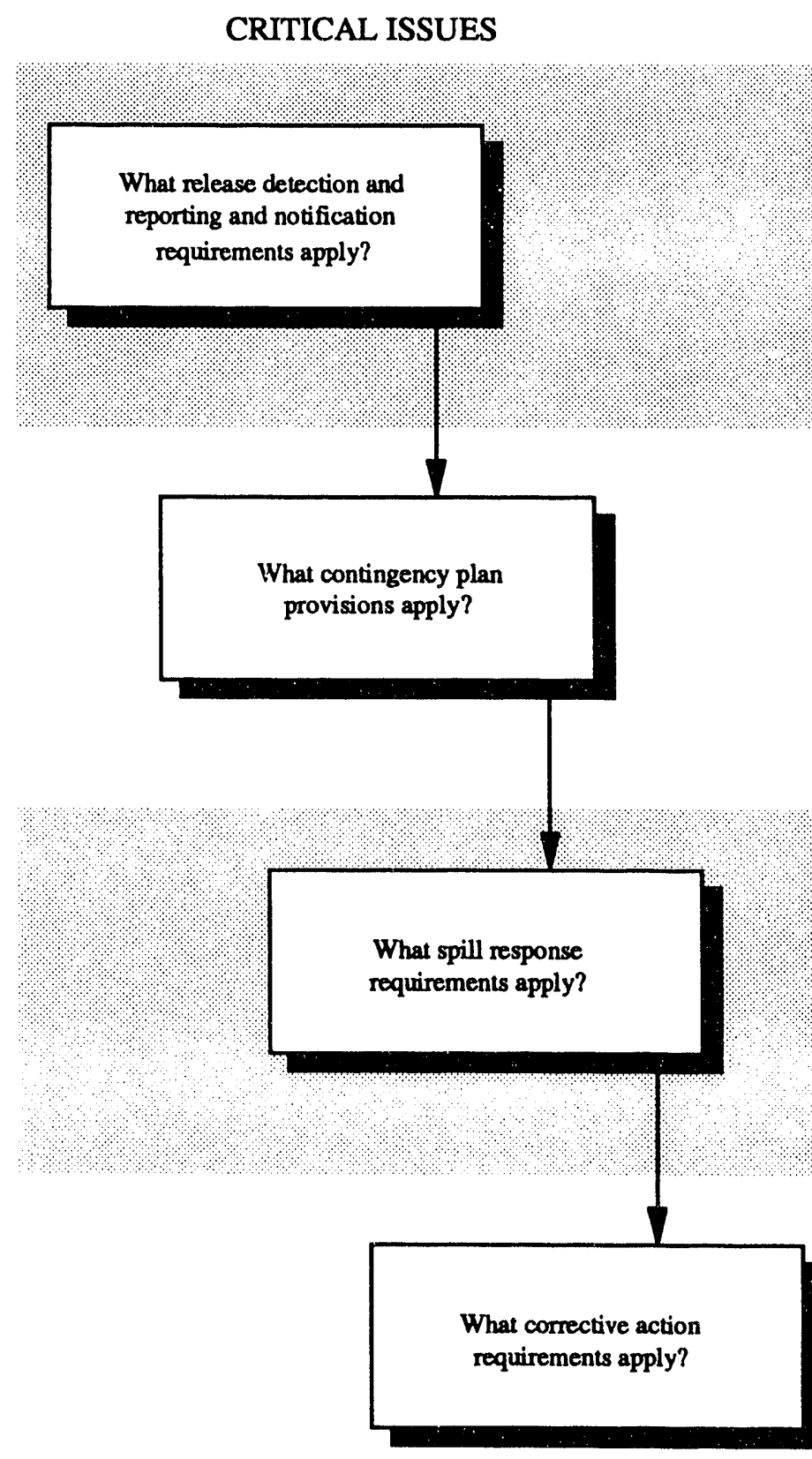
SUBMODULES CONTAINING GUIDANCE ON CRITICAL ISSUES

SUBMODULE 4.1

SUBMODULE 4.2

SUBMODULE 4.3

SUBMODULE 4.4 


\section{Module 4: Flowchart}

\section{SUBMODULE 4.1: RELEASE DETECTION AND REPORTING}

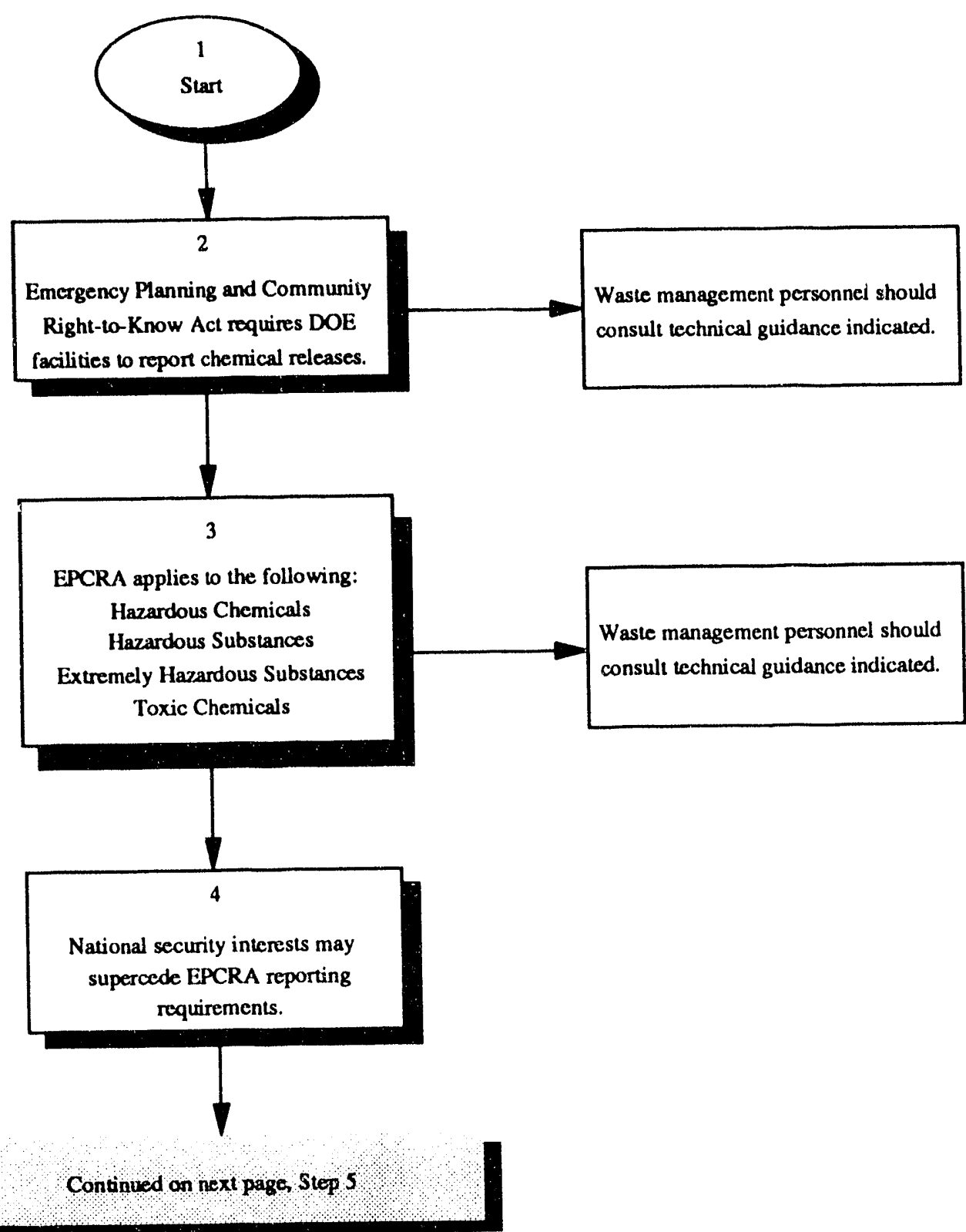


Step $1 \quad$ Start.

Step 2 The Emergency Planning and Community Right-to-Know Act (EPCRA) of 1986, also known as Title III of the Superfund Amendments and Reauthorization Act (SARA), establishes two important release detection and reporting requirements that may be relevant for container storage areas at DOE facilities. These requirements irclude (1) emergency release notification and (2) reporting on releases for community right-to-know.

EPCRA also contains requirements for emergency planning notification and non-release related reporting requirements that may apply to DOE facilitios; however, these requirements are not discussed in this submodule. Waste management personnel should consult the following materials for detailed guidance on these requirements:

- $\quad$ Module 2, "Emergency Planning" of Emergency Planning and Community Right-ToKnow Act, U.S. Department of Energy, Office of Environmental Guidance, RCRA/CERCLA Division, EH-231;

- Hazardous Materials Emergency Planning Guide, National Response Team, NRT-1, March 1987;

- $\quad$ Module 4, "Community Right-to-Know" of Emergency Planning and Community Right-To-Know Act, U.S. Department of Energy, Office of Environmental Guidance, RCRA/CERCLA Division, EH-231; and

- It's Not Over in October; $A$ Guide for Local Emergency Planning Committees; Implementing the Emergency Planning and Community Right-to-Know Act of 1986, U.S. Environmental Protection Agency, Office of Solid Waste and Emergency Response, OSWER-90-004.

Step 3

EPCRA identifies four, somewhat overlapping, groups of chemicals that waste management personnel must identify at their facility. These four groups are Hazardous Chemicals (HCs); Hazardous Substances (HSs); Extremely Hazardous Substances (EHSs); and Toxic Chemicals (TCs). Note that RCRA hazardous wastes are defined as HSs under $E P C R A$. Waste management personnel must distinguish between these groupings because they are the basis for different EPCRA requirements. Waste management personnel should consult the following for detailed guidance on these requirements;

- $\quad$ Module 1, "Chemical Inventory" of Emergency Planning and Community Right-ToKnow Act, U.S. Department of Energy, DOE/EH-0181P, March 1991. Office of Environmental Guidance, RCRA/CERCLA Division, EH-231;

- 40 CFR 355, Appendices A \& B;

- $\quad 40$ CFR 372.65; and

- $\quad 40$ CFR 302.4 .

Step 4 DOE facilities are to comply with EPCRA reporting requirements; however, Section $120(j)$ of SARA provides for an exemption from EPCRA reporting requirements in the interest of national security. In addition to this section of SARA, waste management personnel should refer to SEN-11-89 to assist them in making decisions regarding compliance with EPCRA and the protection of national security. 


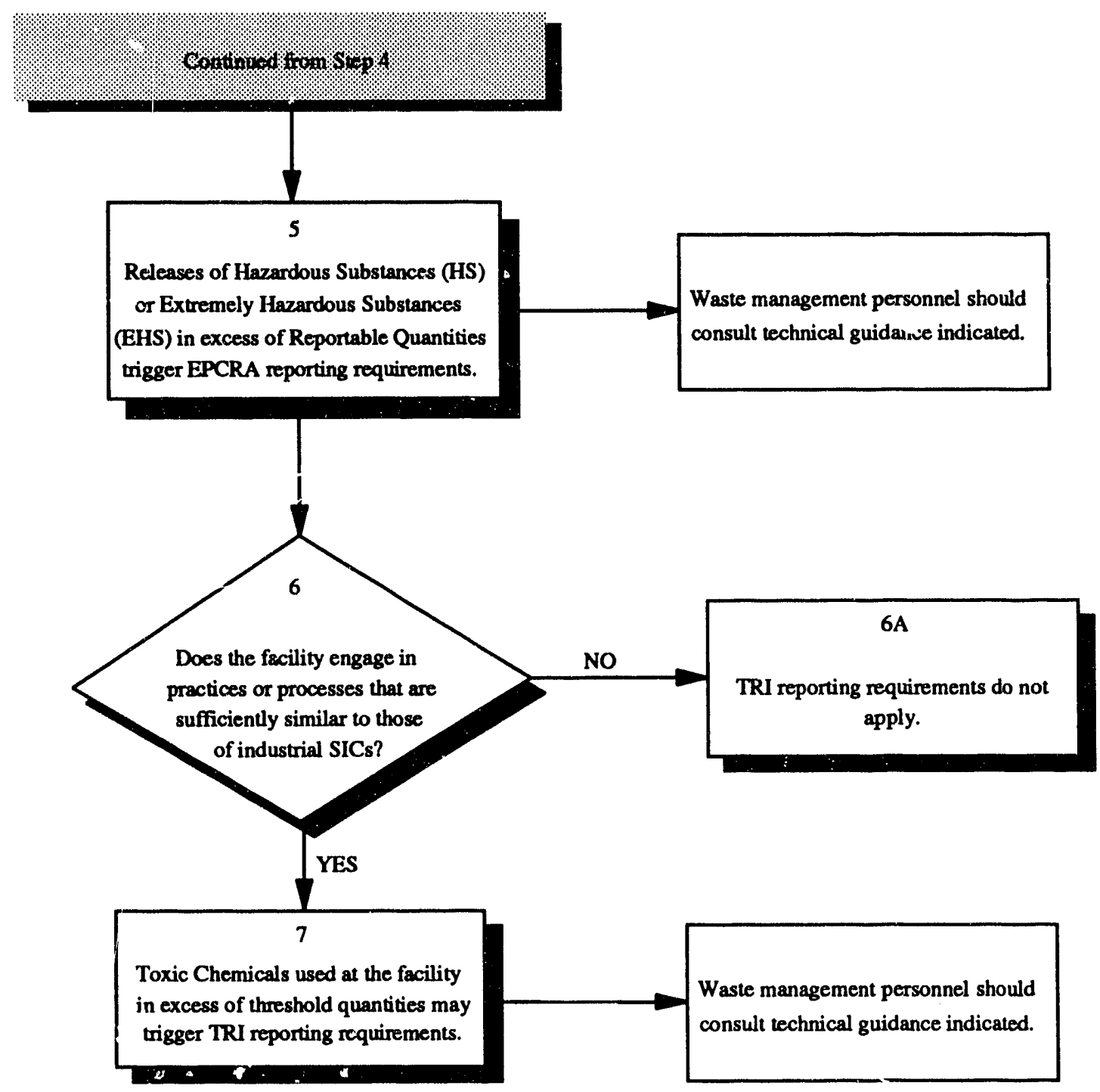


Any time a Hazardous Substance (HS) (40 CFR 302.4) or Extremely Hazardous Substance (EHS) ( 40 CFR Part 355, Appendices A \& B) is released into the environment in excess of the Reportable Quantity (RQ) specifically established for each HS or EHS, waste management personnel may be required to notify the National Response Center, the State Emergency Response Commission, and Local Emergency Planning Committee(s).

Certain releases are exempt from notification requirements. These exemptions include federally permitted releases (40 CFR 355.20, 355.40; CERCLA Section 101(10) and (22); and CERCLA 103(E)); continuous releases (CERCLA 103(e)); and other excluded releases ( $40 \mathrm{CFR} 302.3$ ). For detailed guidance on detecting releases, notification requirements, and exempt releases under EPCRA, waste management personnel should consult the following materials:

- $\quad$ Module 3, "Emergency Release" of Emergency Planning and Community Right-ToKnow Act, U.S. Department of Energy, Office of Environmental Guidance, RCRA/CERCLA Division, EH-231;

- 1987 Emergency Response Guidebook, U.S. Department of Transportation, Office of Hazardous Materials Transportation, DMH-50, September 1987; and

- $\quad$ Reporting Releases of Hazardous Substances, U.S. Department of Energy, Office of Environmental Guidance, RCRA/CERCLA Division, EH-CER-001/0490, April 1990.

- $\quad$ Preparation of RCRA Contingency Plans, DOE/EH-0274, July 1992.

Step 6

Step 6A

Step 7

Section 313 of EPCRA establishes additional reporting requirements under the Federal Toxic Chemical Release Inventory (TRI) that may be applicable to some DOE facilities. Unlike the release reporting requirements discussed in Step 5, TRI reporting requirements are applicable to DOE facilities, or components thereof, engaging in practices or processes that are sufficiently similar to those conducted within industrial SICs (codes $20-39$ ).

If a DOE facility contains none of the subject operations, TRI release reporting requirements do not apply.

The chemical on the TRI are listed in 40 CFR 372.65. Release, disposal, treatment, or storage of any TRI chemical used at the facility in excess of threshold quantities (40 CFR 372.25) requires waste management personnel to comply with annual reporting requirements. Reports are sent to EPA and State authorities. Waste management personnel should consult the following materials for technical guidance on reporting requirements under the TRI:

- Module 5, "Toxic Release Inventory" of Emergency Planning and Community RightTo-Know Act, U.S. Department of Energy, Office of Environmental Guidance, RCRA/CERCLA Division, EH-231;

1 The Emergency Planning and Community Right-To-Know Act, Section 313 Release Reporting Requirements, U.S. Environmental Protection Agency, EPA 560/4-90022; and

- Toxic Chemical Release Inventory Questions and Answers, U.S. Environmental Protection Agency, EPA 560/4-90-003. 


\section{REFERENCES FOR SUBMODULE 4.1}

1) Emergency Planning and Community Right-To-Know Act, U.S. Department of Energy, Office of Environmental Guidance, RCRA/CERCLA Division, EH-231.

2) Emergency Planning and Community Right-to-Know Act (EPCRA), U.S. Department of Energy, Office of Environmental Guidance, RCRA/ CERCLA Division, DOE/EH-0181P, March 1991.

3) Emergency Planning and Community Right-to-Know Act of 1986 Questions and Answers, U.S. Department of Energy, Office of Environmental Guidance, RCRA/CERCLA Division, June 1, 1989.

4) Environmental Protection, Safety, and Health Protection Information Reporting Requirements, U.S. Department of Energy, DOE Order 5484.1, February 24, 1981.

5) Federal Environmental Reporting Requirements, U.S. Department of Energy, Office of Environmental Guidance, RCRA/CERCLA Division, May 1990.

6) The Emergency Planning and Community Right-To-Know Act, Section 313 Release Reporting Requirements, U.S. Environmental Protection Agency, EPA 560/4-90-022.

7) Emergency and Hazardous Chemical Inventory Forms and Community Rightto-Know Reporting Requirements; Final Rule, U.S. Environmental Protection Agency, OSWER-081587, October 15, 1987.

8) It's Not Over in October; $A$ Guide for Local Emergency Planning Committees; Implementing the Emergency Planning and Community Right-to-Know Act of 1986, U.S. Environmental Protection Agency, Office of Solid Waste and Emergency Response, OSWER-90-004.

9) Guidance for Federal Facilities on Release Notification Requirements Under CERCLA and SARA Title III, U.S. Environmental Protection Agency, Office of Emergency Remedial Response, EPA 9360.7-06, November 1990.

10) Reporting Requirements for Continuous Releases of Hazardous Substances -$A$ Guide for Facilities and Vessels on Compliance, U.S. Environmental Protection Agency, EPA/540/G-91/003.

11) Reporting Releases of Hazardous Substances, U.S. Department of Energy, Office of Environmental Guidance, RCRA/CERCLA Division, EH-CER001/0490, April 1990.

12) RCRA Contingency Plans and Emergency Procedures, U.S. Department of Energy, Office of Environmental Guidance, RCRA/CERCLA Division, Information Brief, EH-231-006/0991, September 1991. 


\section{REFERENCES FOR SUBMODULE 4.1 (cont)}

13) Extremely Hazardous Substance List and Threshold Planning Quantities; Emergency Planning and Release Notification Requirements; Final Rule, U.S. Environmental Protection Agency, OSWER-042287, April 27, 1987.

14) Toxic Chemical Release Inventory Questions and Answers, U.S. Environmental Protection Agency, EPA 560/4-90-003.

15) Emergency Planning and Community Right-to-Know Act: a Status of State Actions, National Governors Association, April 1988.

16) 1987 Emergency Response Guidebook, Department of Transportation, Office of Hazardous Materials Transportation, DMH-50, September 1987.

17) Hazardous Materials Emergency Planning Guide, National Response Team, NRT-1, March 1987.

18) 40 CFR Part 302 .- Designation, reportable quantities, and notification.

19) 40 CFR 355 - Emergency planning and notification.

20) 40 CFR 372.65 - Chemicals and chemical categories.

21) Preparation of RCRA Contingency Plans, U. S. Department of Energy, Office of Environmental Guidance, RCRA/CERCLA Division, DOE/EH0274, July 1992. 


\section{Module 4: Flowchart}

\section{SUBMODULE 4.2: CONTINGENCY PLANS}

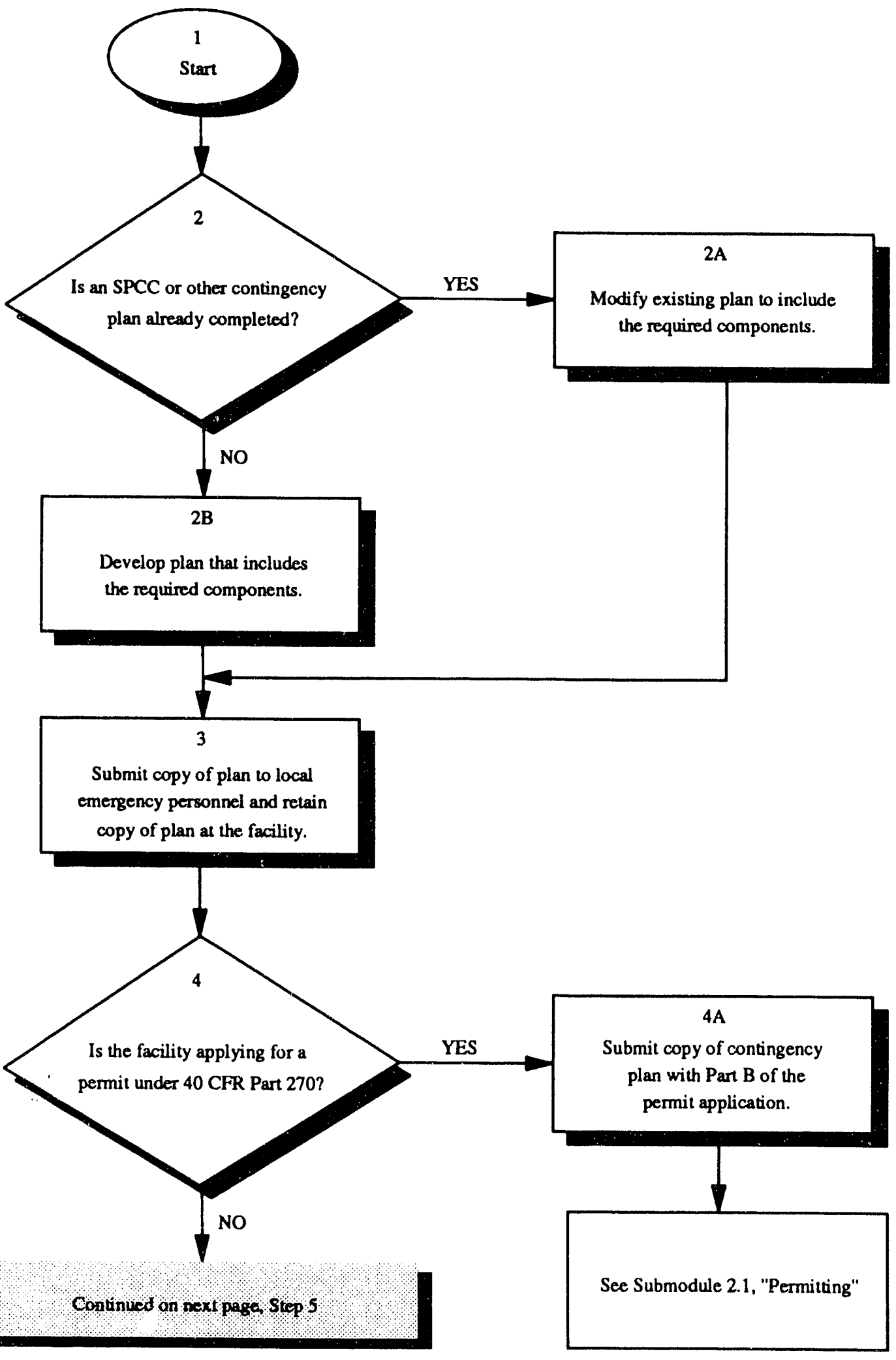




\section{SUBMODULE 4.2 CONTINGENCY PLANS}

Step $1 \quad$ Start.

Step 2 DOE container storage areas for hazardous wastes and radioactive mixed wastes are required to have or be included in a contingency plan. In general, the plan must be designed to minimize threats to human health or the environment from fires, explosions, or any unplanned sudden or non-sudden release of hazardous waste or hazardous waste constituents to air, soil, or surface water (40 CFR 264.51 and 265.51).

Step 2A If waste management personnel have already completed a Spill Prevention, Control, and Countermeasure (SPCC) Plan in accordance with 40 CFR Part 112, or some other emergency or contingency plan, they need only amend the existing plan so that it includes the provisions listed under Step 2B (40 CFR 264.52 and 265.52).

Step 2B If waste management personnel have not already completed an SPCC or other emergency plan, then a contingency plan will have to be developed.

Contingency plans prepared by waste management personnel must contain the following components:

- the actions to be taken in response to any emergencies;

- $\quad$ arrangements with local emergency response personnel (e.g., police departments, fire departments, hospitals, and contractors) to coordinate emergency services;

- the names, addresses, and work and home phone numbers of all persons qualified to serve as emergency coordinator -- one person at the facility must be designated as primary coordinator, while the remaining persons should be listed in the order in which they will assume responsibility;

- a list of all emergency equipment at the container storage area (e.g., fire extinguishers, spill containment equipment, and decontamination equipment), including the location, a physical description, and the capabilities of each item on the list; and

- an evacuation plan for facility personnel, including the signal to be used to begin evacuation, and primary and alternate evacuation routes.

Step 3 Waste management personnel must retain a copy of the contingency plan at the facility. In addition, a copy of the plan must be submitted to all State and local emergency response personnel that may be called upon to provide emergency services (40 CFR 264.53 and 265.53).

Step 4 Submodule 2.3, "Permitting," should be referenced to determine if the facility must apply for a permit.

Step 4A Any facility applying for a permit under 40 CFR Part 270 must submit a copy of the contingency plan with Part B of the permit application. 


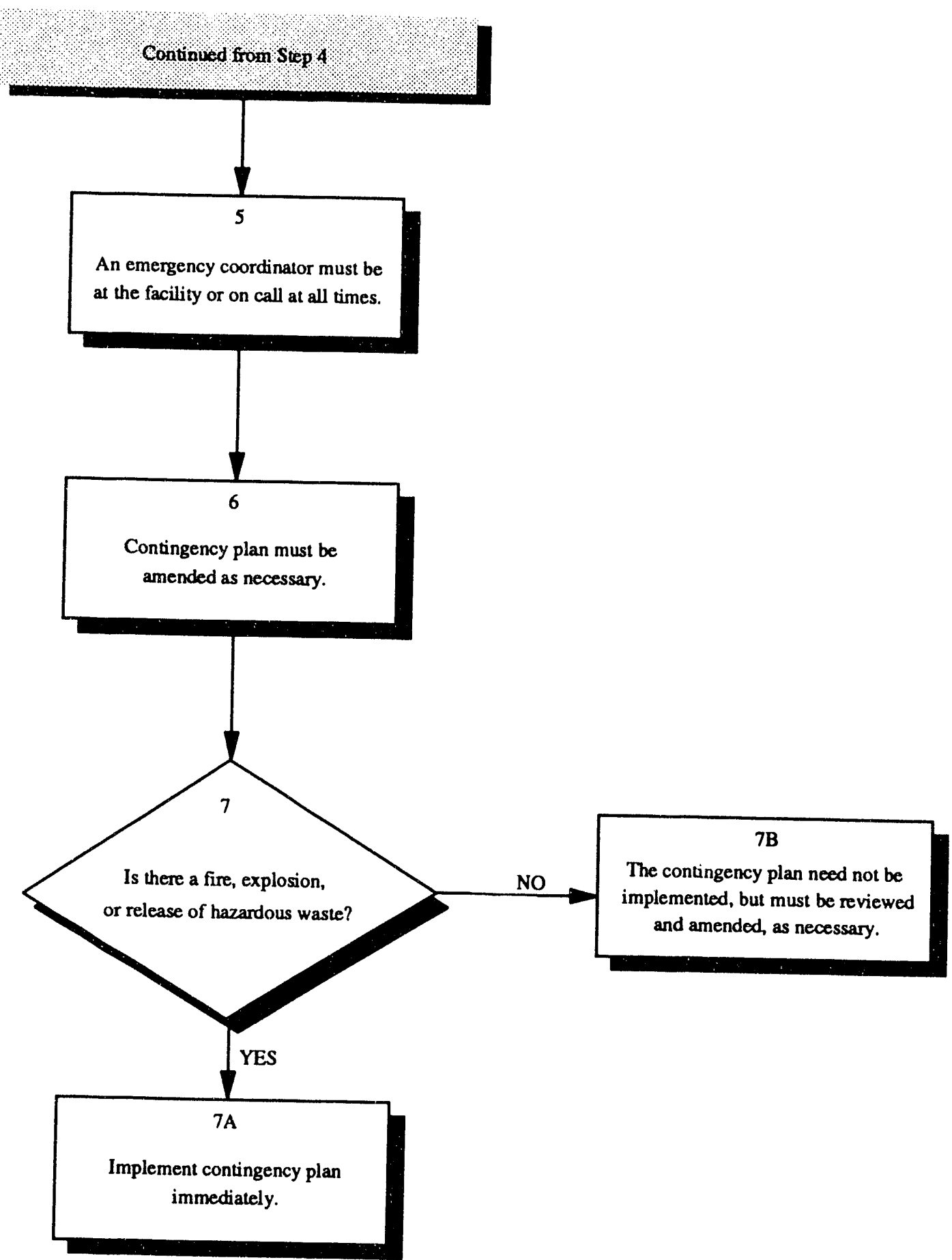


DOE facilities must have an emergency coordinator at the facility or on call at all times. The coordinator must be familiar with the container storage area's contingency plan, all operations and activities at the container storage area, the location and characteristics of all wastes handled, the location of all records in the container storage area, and the container storage area layout. In addition, the coordinator must have the authority to commit the resources needed to carry out the contingency plan.

Step 6 Waste management personnel must review and amend the contingency plan, if necessary, in the event:

- the facility permit is revised;

- the plan fails in an emergency;

- the facility changes in its design, construction, or operating and maintenance procedures in a manner that increases the potential for fires, explosions, or releases;

- the list of emergency coordinators changes; or

- the list of emergency equipment changes.

Step 7 Use of the contingency plan is triggered whenever there is a fire, explosion, or release of hazardous waste or hazardous waste constituent which could threaten human health or the environment.

Step 7A The provisions of the contingency plan must be carried out immediately and in full. If the plan fails, it must be modified (see Step 6).

Step 7B The contingency plan need only be implemented in the event of such an emergency. However, DOE personnel must be prepared to review and modify the plan as per Step 6.

\section{REFERENCES FOR SUBMODULE 4.2}

1) RCRA Contingency Plans and Emergency Procedures, U.S. Department of Energy, Office of Environmental Guidance, RCRA/CERCLA Division, Information Brief, EH-231-006/0991, September 1991.

2) Preparation of RCRA Contingency Plans, U.S. Department of Energy, Office of Environmental Guidance, RCRA/CERCLA Division, DOE/EH-0274, July 1992.

3) 40 CFR 264 Subpart D -- Contingency plan and emergency procedures.

4) 40 CFR Part 112 -- Oil pollution prevention. 


\section{Module 4: Flowchart}

\section{SUBMODULE 4.3: SPILL RESPONSE}

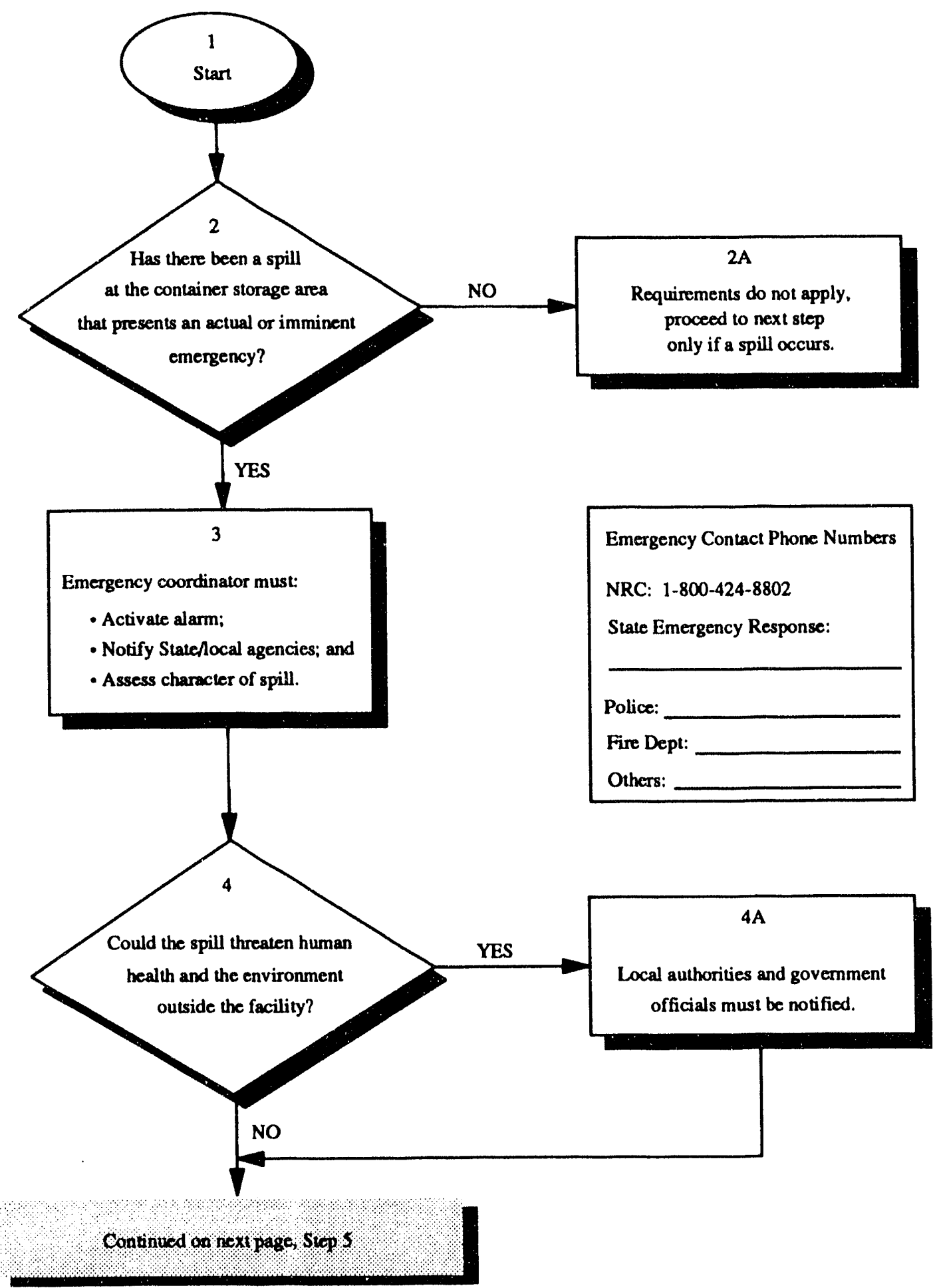


Step 1

Step 2

Step 2A

Step 3

Step 4

Step 4A
Start.

These requirements apply to any DOE container storage area at which a spill of hazardous or radioactive mixed waste that represents an actual or imminent emergency situation occurs (40 CFR 264.56 and 265.56).

Absent a spill, the requirements below do not apply, but may in the future if a spill occurs.

In the event of a spill, the emergency coordinator, or his designee, must immediately:

- activate internal alarms or communication systems to notify all facility personnel;

- notify appropriate State or local agencies with response roles if their help is needed; and

- $\quad$ immediately assess the character, exact source, amount, and areal extent of the spill. This assessment may be done by observation or review of records or manifests, and, if necessary, by chemical analysis. In addition, the emergency coordinator must assess possible hazards to human health or the environment that may result from the spill. This assessment must consider both direct and indirect effects of the release.

Additional notification requirements apply if it is determined during the spill assessment that the spill could threaten human health or the environment outside the property line of the facility.

If the emergency coordinator determines that the spill could threaten human health or the environment outside the property line of the facility, the coordinator must take the following actions:

- notify the appropriate local authorities if the evacuation of local areas may be advisable and assist the authorities in determining if evacuation is advisable; and

- notify the government official designated as the on-scene coordinator for that geographic area or notify the National Response Center (800/424-8802). If radioactive substances are present in the spill, the EPA radiological response coordinator should be notified for evaluation and assistance. The report to the appropriate official must include the name and telephone number of the reporter, name and address of the facility, time and type of incident (e.g., container spill), name and quantity of materials involved, the extent of injuries, and the possible hazards to human health or the environment outside the facility.

For more information on proper notification requirements in the event of release, see Submodule 4.1, "Release Detection and Reporting." 
Conued from S $p \mathrm{P} 4$

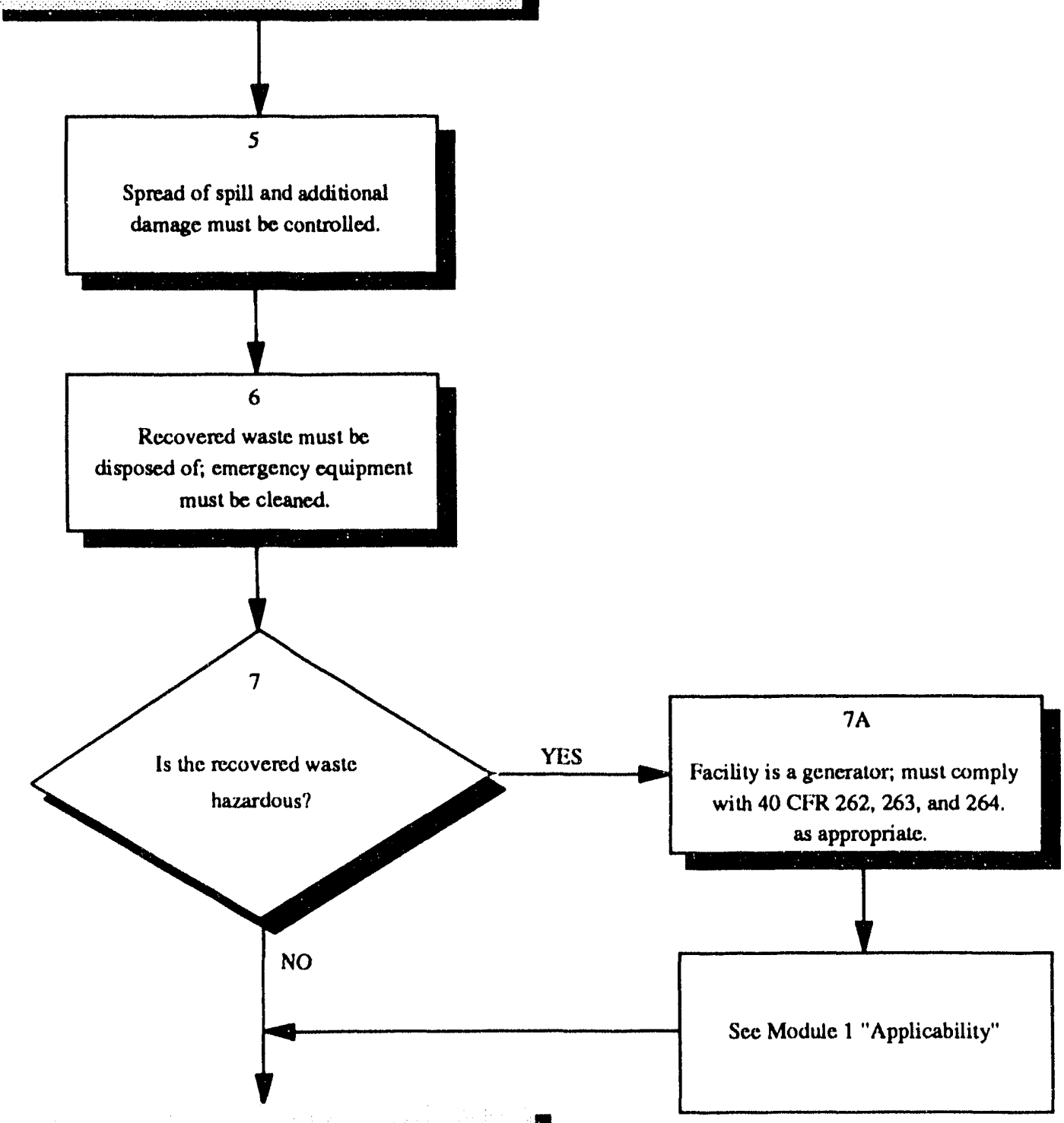

Continued on next page, Step 8 
During the spill and spill cleanup, the emergency coordinator must control the spread of the spill and prevent other damage from occurring to containers that might worsen the threat from the spill. These measures must include, where applicable, stopping processes and operations, collecting and containing release waste, and removing or isolating containers. If operations are stopped during a spill or spill cleanup, the emergency coordinator must monitor for leaks, gas generation, etc. In addition, the emergency coordinator must ensure that no waste incompatible with the released waste are treated, stored, or disposed of until spill cleanup is complete.

Step 6 The emergency coordinator must arrange for treatment, storage, or disposal of recovered waste, contaminated soil or surface water, or any other material resulting from the spill. In addition, all emergency equipment listed in the contingency plan must be cleaned and ready for its intended use before operations resume. Waste management personnel must notify the appropriate EPA Regional Administrator, and appropriate State and local authorities, that the container storage area has complied with the requirements for incompatible wastes and cleanup of emergency equipment (40 CFR 264.50-264.56).

Step 7 If waste management personnel can demonstrate that the recovered material is not a hazardous waste, then the container storage area is not subject to hazardous waste generator requirements.

Step 7A Unless waste management personnel can demonstrate that the recovered material is not a hazardous waste, the container storage area is considered a generator of hazardous waste and must manage it in accordance with all applicable requirements of 40 CFR Parts 262, 263, and 264. For additional information, waste management personnel should consult Module 1, "Applicability." 


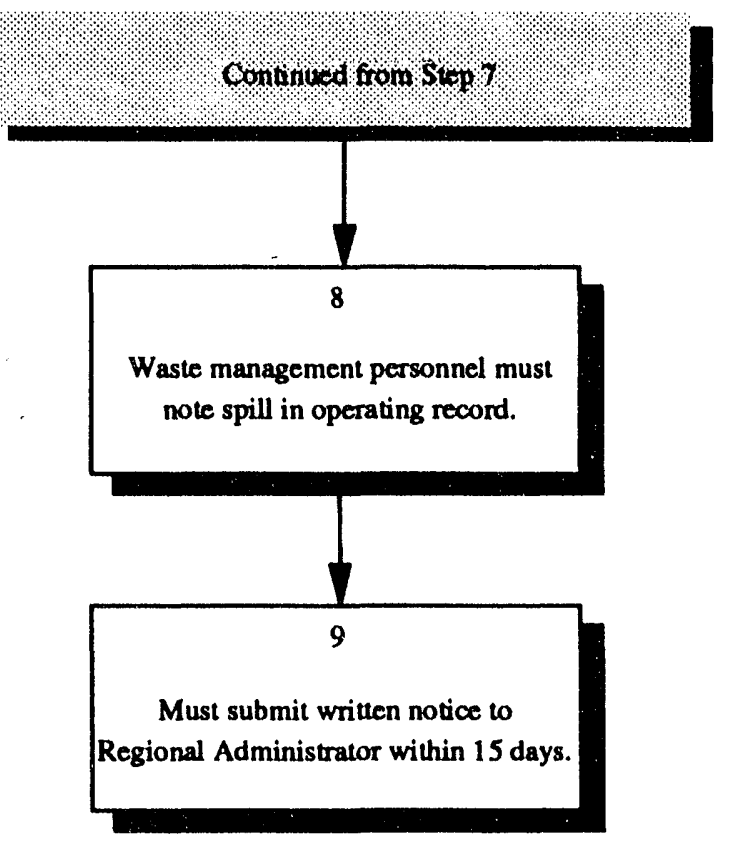


Step 8

Step 9
Waste management personnel must note in the operating record the time, date, and details of any container spill requiring implementation of the contingency plan.

A written report must be submitted to the Regional Administrator or State Director within 15 days after the spill. The report must include the following information:

- name, address, and telephone number of the waste management personnel responsible for operating the container storage area;

- date and time of the spill;

- name and quantity of materials involved;

- the extent of injuries, if any;

- an assessment of actual or potential hazards to human health or the environment, where this is applicable; and

- estimated quantity and disposition of recovered material that resulted from the spill.

\section{REFERENCES FOR SUBMODULE 4.3}

1) Preparation of RCRA Contingency Plans, U. S. Department of Energy, Office of Environmental Guidance, RCRAVCERCLA Diviston, DOE,EH0274, July 1992.

2) RCRA Contingency Plans and Emergency Procedures, U. S. Department of Energy, Office of Envitonmental Guidance, RCRA/CERCLA Division, Information Brief, EH-231-006/0991, September 1991.

3) Guidance Document for Cleanup of Surface Tank and Drum Sites, Final, U.S Environmental Protection Agency, Office of Emergency Remedial Response, OSWER Directive No. 9380.0-03, May 1985.

4) 40 CFR 264 Subpart D - Contingency plan and emergency procedures.

5) See also references in Submodule 4.1, "Release Detection Reporting." 


\section{Module 4: Flowchart}

\section{SUBMODULE 4.4: CORRECTIVE ACTION}

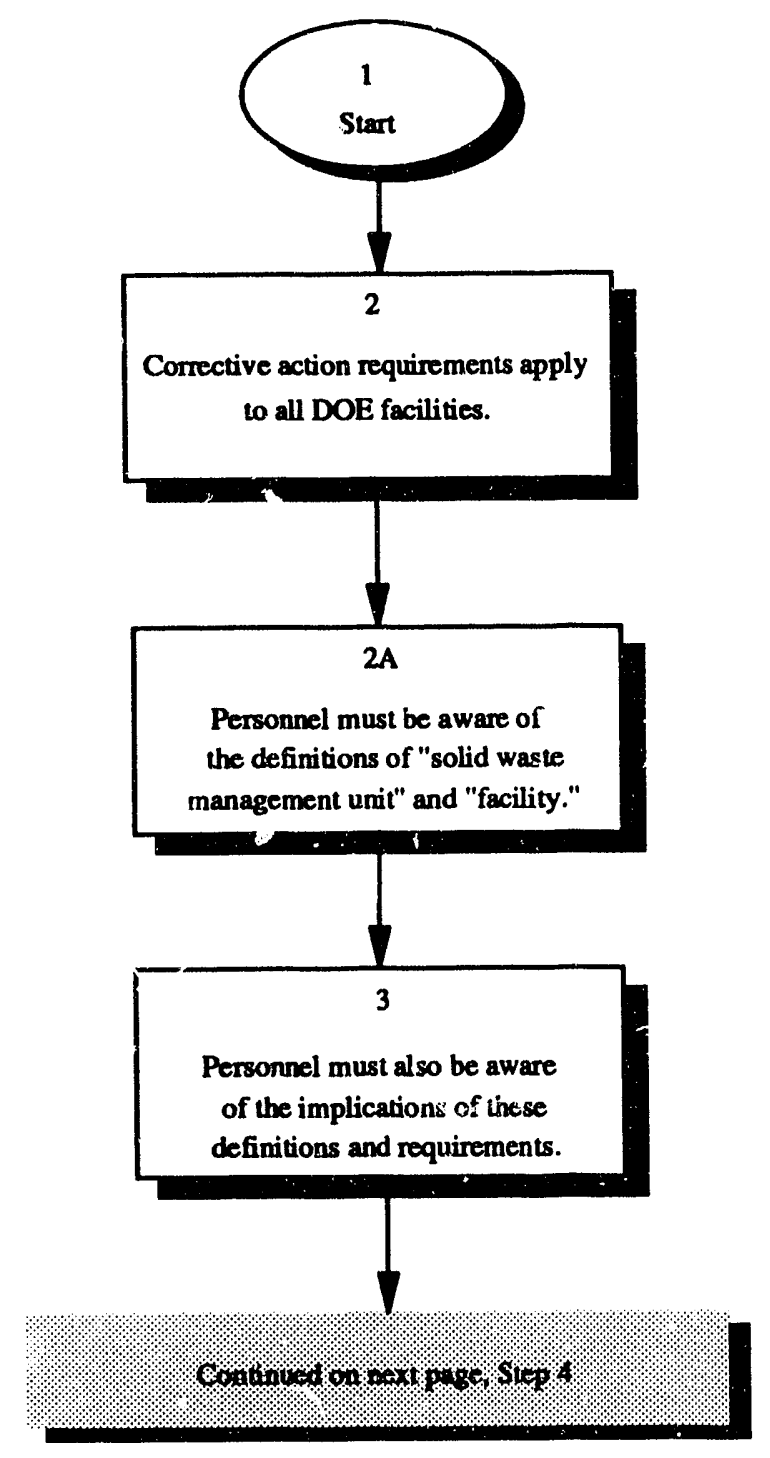


Step $1 \quad$ Start.

Step 2 RCRA corrective action requirements apply to all DOE facilities seeking permits under Subtitle $C$ at which there are releases of hazardous wastes or hazardous constituents from any solid waste management unit (SWMU) at the facility, regardless of when the wastes were placed in the unit (40 CFR 264.101).

Step 2A A SWMU is defined as "any discernible unit at which solid wastes have been placed at any time, irrespective of whether the unit was intended for the management of hazardous or solid waste." Such units include any area of the facility at which solid wastes have been routinely and systematically released (e.g., a loading dock at a container storage area at which spills occur with regularity). In the context of corrective action, a facility is defined as all contiguous property under the control of the owner/operator (DOE) of a facility seeking a permit under Subtitle C (55 FR 30808).

Step 3 The implications for container storage areas at DOE facilities of the corrective action requirement of 40 CFR 264.101 and the definitions of "SWMU" and "facility" are as follows:

- if a single unit within a facility applies for a permit, all the units at the facility may be affected. If waste management personnel operating a container storage area or any SWMU at a DOE facility apply for a permit, DOE may be required to take corrective action to address a release at any SWMU at the facility, even if the unit is inactive or never accepted DOE wastes.

- properties that are not physically in contact may be part of a single facility. The term "contiguous property" in the context of a facility, is broadly defined. In other words, DOE property that is separated by a stream, roadway, high-power transmissicn line, or $\mathrm{C}$ ther such property may be considered contiguous, and is therefore consicered a single facility for the purposes of corrective action.

- $\quad$ corrective action requirc nents apply to both permitted and interim status facilities. EPA is authorize to address corrective action through the permit process pursuant to RCRA s'"ction 3004(u) and 3004(v). Corrective action at interim status facilities may be addressed through a corrective action enforcement order issued pursuant to RCRA Section $3008(\mathrm{~h})$.

- the term "release" is defined broadly to include both hazardous wastes and hazardous constituents. Hazardous wastes include those listed in 40 CFR Part 261 , or any "characteristic" hazardous waste (i.e., ignitible, corrosive, reactir'e, or toxic) as defined in 40 CFR 261.20 through 261.24. Hazardous constituents are listed in 40 CFR Part 261, Appendix XIII, and 40 CFR Part 264, Appendix IX. EPA used this broad definition because of its concern about addressing releases of hazardous constituents (e.g., lead, cadmium) that may have originated from wastes that are not necessarily defined as hazardous under RCRA.

- $\quad$ cleanup requirements at DOE facilities may be implemented under different statutory authorities. Corrective action at DOE facilities may be implemented either under RCRA, CERCLA, or both. State statutes may also apply. The choice of authority for implementing corrective action will generally be determined by negotiating a Federal facility agreement (FFA) in the form of an interagency agreement (IAG). 


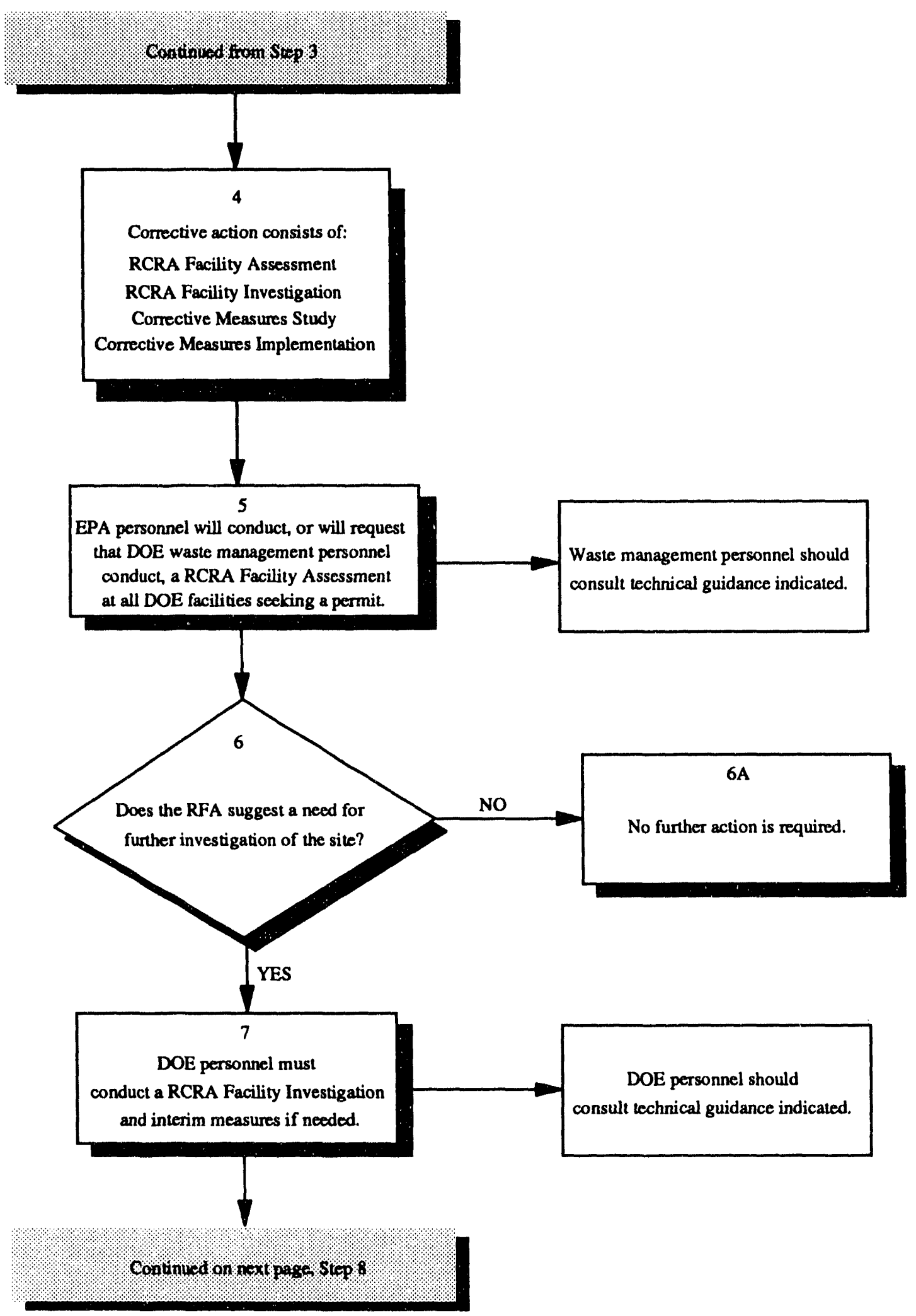


Detailed requirements and procedures for corrective action have not yet been finalized, therefore EPA has been implementing corrective action largely through guidance (see references at the end of this submodule). There are four components to the corrective action process. These components are: RCRA Facility Assessment, RCRA Facility Investigation, Corrective Measures Study, and Corrective Measures Implementation. waste management personnel should also refer to the recently proposed Subpart S (55 FR 30798) corrective action rule for more information.

Step 5

Step 6

A RCRA Facility Assessment (RFA) is performed to determine areas of potential release of hazardous wastes or hazardous constituents at RCRA facilitics and to identify releases or suspected releases needing further investigation. In most cases the RFA will be performed by DOE personnel; however, EPA or State personnel may elect to prepare the RFA based on information provided by DOE personnel and on regular site inspections. Note that a Preliminary Assessment/Site Investigation (PA/SI) conducted under CERCLA may perform the same function as an RFA. Because of its Federal facility standing, in most cases, who conducts the RFA, and under what authority it is conducted, will be determined though an IAG. For additional guidance on conducting RFAs, waste management personnel should consult the following:

- $\quad$ Corrective Action Plan, U. S. Environmental Protection Agency, Office of Waste Programs Enforcement, OSWER 9902.3, November 1986.

- $\quad$ Practical Guide for Assessing and Remediating Contaminated Sites, U. S. Environmental Protection Agency, Office of Solid Waste, May 1989.

- RCRA Facility Assessment Guidance, U. S. Environmental Protection Agency, Office of Solid Waste, October 1986.

If, as a result of the RFA, further investigation is warranted, DOE personnel will conduct a RCRA Facility Investigation (RFI) to verify that a release has occurred and to characterize the nature, extent, and rate of migration of the release.

Step 6A If no further investigation is indicated by the RFA, no further action is required.

Step 7 Depending on the type of release, the RFI will generally involve activities such as soil sampling, ground-water monitoring, and surface water monitoring. If during the course of the RFI, interim corrective measures are determined to be necessary to address an immediate threat, DOE personnel will implement these interim corrective measures. For additional technical guidance on conducting RFIs or interim corrective measures, DOE personnel should consult the following:

- RCRA Facility Investigation Guidance, U.S. Environmental Protection Agency, Office of Solid Waste, OSWER Directive No. 9502.00.6C, July 1987.

- RCRA Corrective Action Interim Measures, Interim Final, U. S. Environmental Protection Agency, Office of Waste Programs Enforcement, Office of Solid Waste, OSWER Directive No. 9902.4, June 1988. 


\section{Conitivud from sup?}

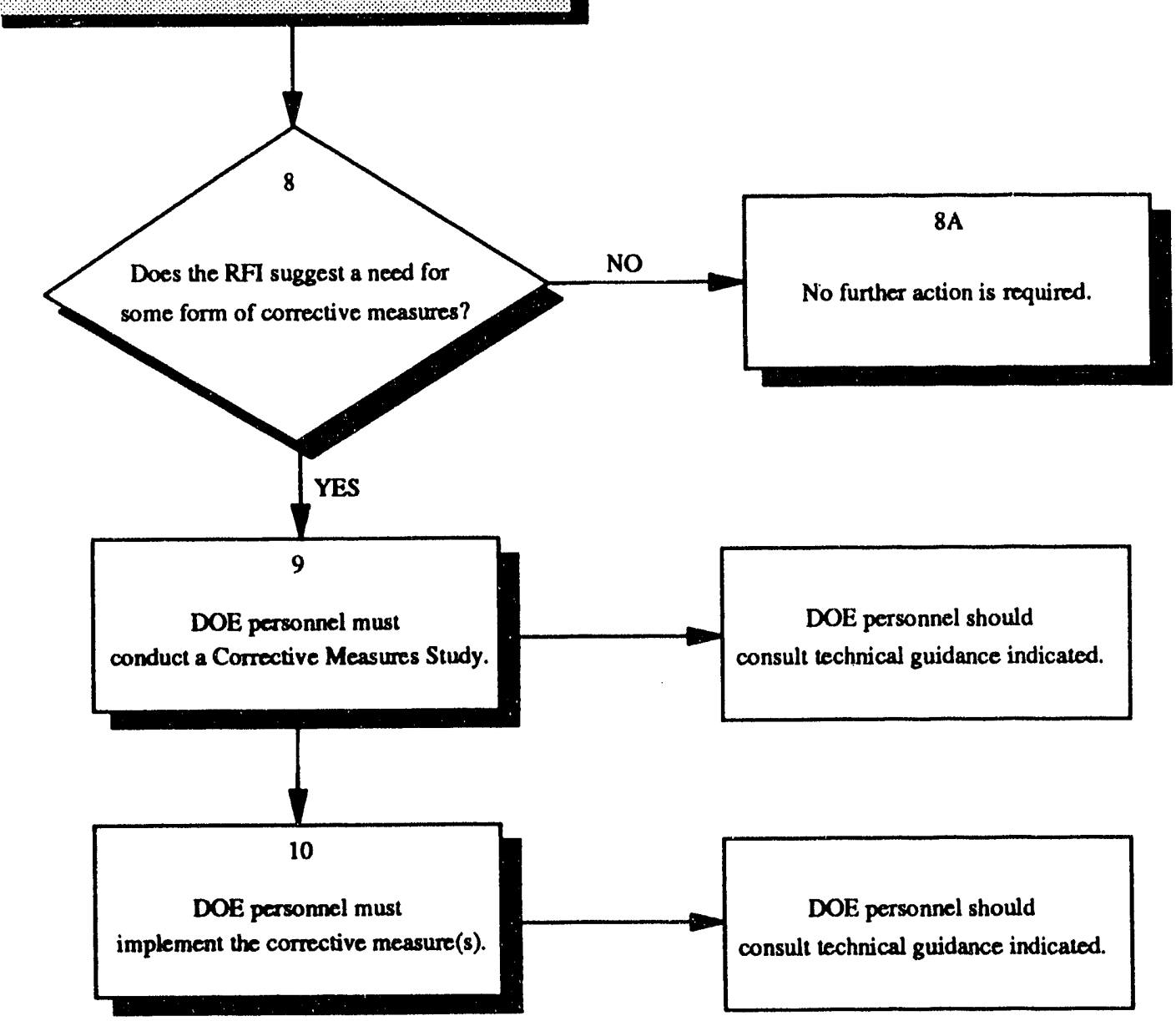


If the RFI determines that some sort of corrective measure is required, DOE personnel will conduct a Corrective Measures Study (CMS).

Step 8A If the RFI does not suggest a need for corrective measures, no further action is required.

Step 9 The purpose of a CMS is to develop and evaluate various corrective measure alternatives and to recommend a final corrective measure or measures. For additional technical guidance on conducting CMSs, DOE personnel should consult the following:

- $\quad$ Corrective Measures for Releases to Ground Water from Solid Waste Management Units, U.S. Environmental Protection Agency, Office of Solid Waste, Draft Final, PB88-185251;

- $\quad$ Corrective Measures for Releases to Soil from Solid Waste Management Units, U.S. Environmental Protection Agency, Office of Solid Waste, PB88-185277, August 1985;

- $\quad$ Corrective Measures for Releases to Surface Water, U.S. Environmental Protection Agency, Office of Solid Waste, Draft Final, PB88-185251; and

- $\quad$ Technical Guidance for Corrective Measures: Determining Appropriate Technology and Response for Air Releases, U.S. Environmental Protection Agency, Office of Solid Waste, PB88-185269, March 1985.

Step 10 The final step in the corrective action process is the Corrective Measures Implementation (CMI). The objective of the CMI is to design, construct, operate, maintain, and monitor the performance of the corrective measure or measures selected as a result of the CMS. It is conceivable that one of the options considered in the CMS will be a "do nothing" option; however, in nearly every case, a CMS will eventually lead to some sort of corrective measures being implemented. For additional technical guidance on implementing corrective measures, DOE personnel should consult the guidance manuals listed above in Step 9 as well as the following publication.

- Remedial Action at Waste Disposal Sites, U.S. Environmental Protection Agency EPA/625/6-85/006, June 1985. 


\section{REFERENCES FOR SUBMODULE 4.4}

1) Corrective Action Plan, U.S. Environmental Protection Agency, Office of Waste Programs Enforcement, OSWER 9902.3, November 1986.

2) Corrective Measures for Releases to Ground Water from Solid Waste Management Units, U.S. Environmental Protection Agency, Office of Solid Waste, Draft Final, PB 88-185251.

3) Corrective Measure for Releases to Soil from Solid Waste Management Units, U.S. Environmental Protection Agency, Office of Solid Waste, PB88. 185277. August 1985.

4) Corrective Measure for Releases to Surface Water, U.S. Environmental Protection Agency, Office of Solid Waste, Draft Final, PB88-185251.

5) RCRA Facitity Assessment Guidance, U. S. Environmental Protection Agency, Office of Solid Waste, October 1986.

6) RCRA Comective Action Interim Measures, Interim Final, U.S.

Environmental Protection Agency, Office of Waste Programs Enforcement, Office of Solid Waste, OSWER Directive No. 9902.4, June 1988.

7) RCRA Facility Investigation (RFI) Guidance, U,S. Environmental Protection Agency, Office of Solid Waste, OSWER Directive No. $9502.00 .6 \mathrm{C}$, July 1987.

8) Technical Guidance for Corrective Measures: Determining Appropriate Technology and Response for Air Releases, U.S. Environmental Protection Agency, Office of Solid Waste, PB88-185269, March 1985.

9) 40 CFR 264.100 - Corrective action program.

10) 40 CFR 264.101 - Corrective action for solid waste management units.

11) 40 CFR 264 Subpart S (proposed) - Corrective action.

12) RCRA Corrective Action Program Guide (Interim), U. S. Department of Energy, Office of Environmental Guidance, RCRA/CERCLA Division, DOE/EH-0323, May 1993. 


\section{MODULE 5}

\section{CLOSURE}

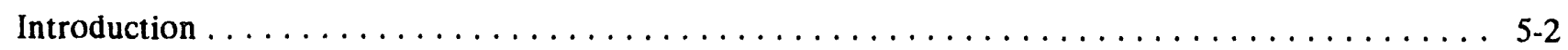

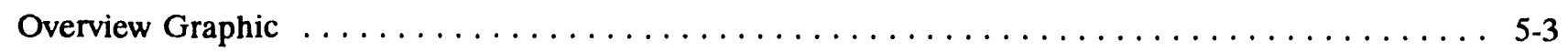

Module 5 - Closure of RCRA Container Storage Areas $\ldots \ldots \ldots \ldots \ldots \ldots \ldots \ldots \ldots \ldots$ 


\section{Introduction to Module 5: Closure}

This module provides guidance on closure requirements for hazardous and radioactive mixed waste container storage areas at DOE facilities. The regulatory requirements for container storage areas at both interim status and permitted facilities have remained unchanged since 1981. When the Subpart I regulations were promulgated on May 19,1980, no specific closure standards were promulgated for permitted or interim status container storage facilities. In 1981 (46 FR 2831), EPA stated that the closure requirements found in Part 265, Subpart G, were applicable to interim status container storage facilities. To clarify their position and to be consistent with the existing closure requirements of tanks (Subpart J), EPA promulgated a closure standard applicable to permitted container storage areas in Part 264. As of April 1992, EPA has not incorporated the same specific requirements in Part 265.

Waste management personnel should use this module to:

- ensure that a closure plan has been prepared and that it contains all of the necessary elements;

- determine when they must begin closure of a container storage area and when removal of inventory and final closure must be completed; and

- certify, when required, that closure is conducted in accordance with the approved closure plan.

The following flowchart and accompanying narrative discussion guides you step-by-step through the applicable closure requirements for container storage areas. 


\title{
OVERVIEW OF MODULE 5: CLOSURE
}

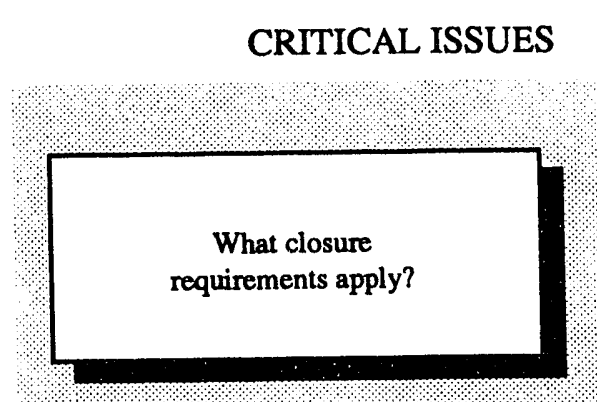

\author{
SUBMODULES CONTAINING GUIDANCE \\ ON CRITICAL ISSUES
}

MODULE 5 


\section{Module 5: Flowchart}

MODULE 5: CLOSURE OF CONTAINER STORAGE AREAS

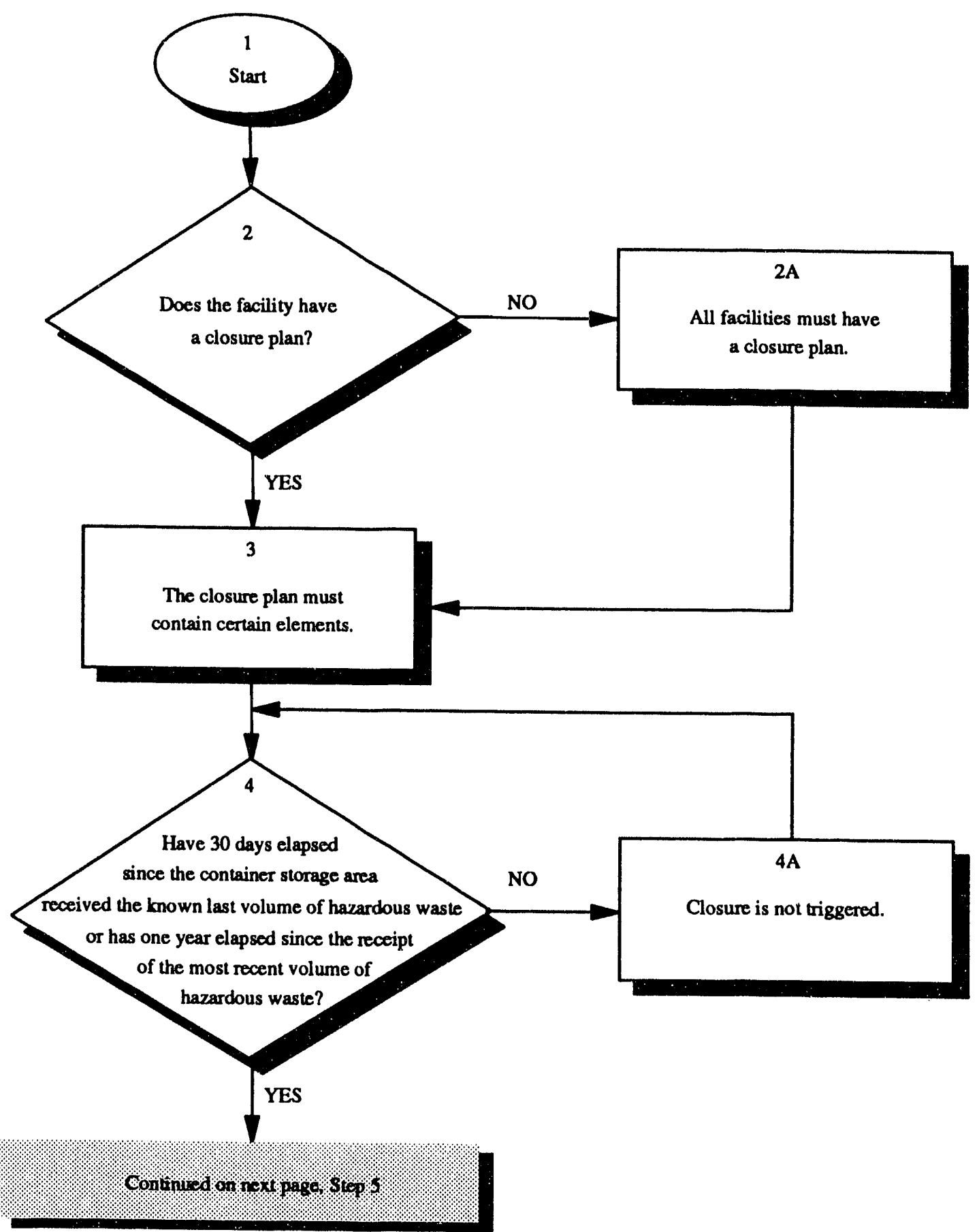




\section{MODULE 5: CLOSURE OF RCRA CONTAINER STORAGE AREAS}

Step $1 \quad$ Start.

Step 2 A closure plan is a detailed description of the activities necessary to close the container storage area at any time during its active life. A closure plan must be submitted as part of the RCRA Part B permit application.

Step 2A All permitted and interim status container storage areas must have a written closure plan as part of their operating requirements.

Step 3 The regulations do not specify any required format for a closure plan; however, at a minimum, a closure plan should include the following elements (40 CFR 264.112 and 265.112):

- a detailed description of the container storage area (e.g., location, size, containment system design, security systems);

- a description of other units and facility activities if the container storage area is only one component of a larger treatment, storage, and disposal facility;

- $\quad$ estimates of the maximum number of containers and other hazardous wastes in the container storage area to be removed at closure;

- $\quad$ procedures for removing or decontaminating hazardous waste residues, waste inventory pads, pallets, contaminated containment system components, equipment, structures, subsoils, and groundwater, etc.;

- a schedule of closure activities (including the expected year of closure for interim status facilities without approved closure plans); and

- $\quad \lambda$ description of activities to be conducted to certify closure in accordance with the closure plan (40 CFR 264.115 and 265.115).

For additional details on the preparation of closure plans, see the references at the end of this submodule.

Step 4 The date on which waste management personnel expect to begin closure of a container storage area is defined as either (40 CFR 264.112 (d) and 265.112 (d)):

- $\quad 30$ days after the container storage area receives the known last volume of hazardous or radioactive mixed waste; or

- $\quad$ if there is a reasonable probability that the unit will receive additional hazardous or radioactive mixed waste, one year after the receipt of the most recent volume of such waste. If waste management personnel can demonstrate to the Regional Administrator or State Director that the container storage area has additional capacity to receive waste and that steps have been taken to protect human health and the environment, the container storage area may obtain an extension of the one-year limit.

Step 4A If the conditions outlined in Step 4 are not met, closure is not triggered. 

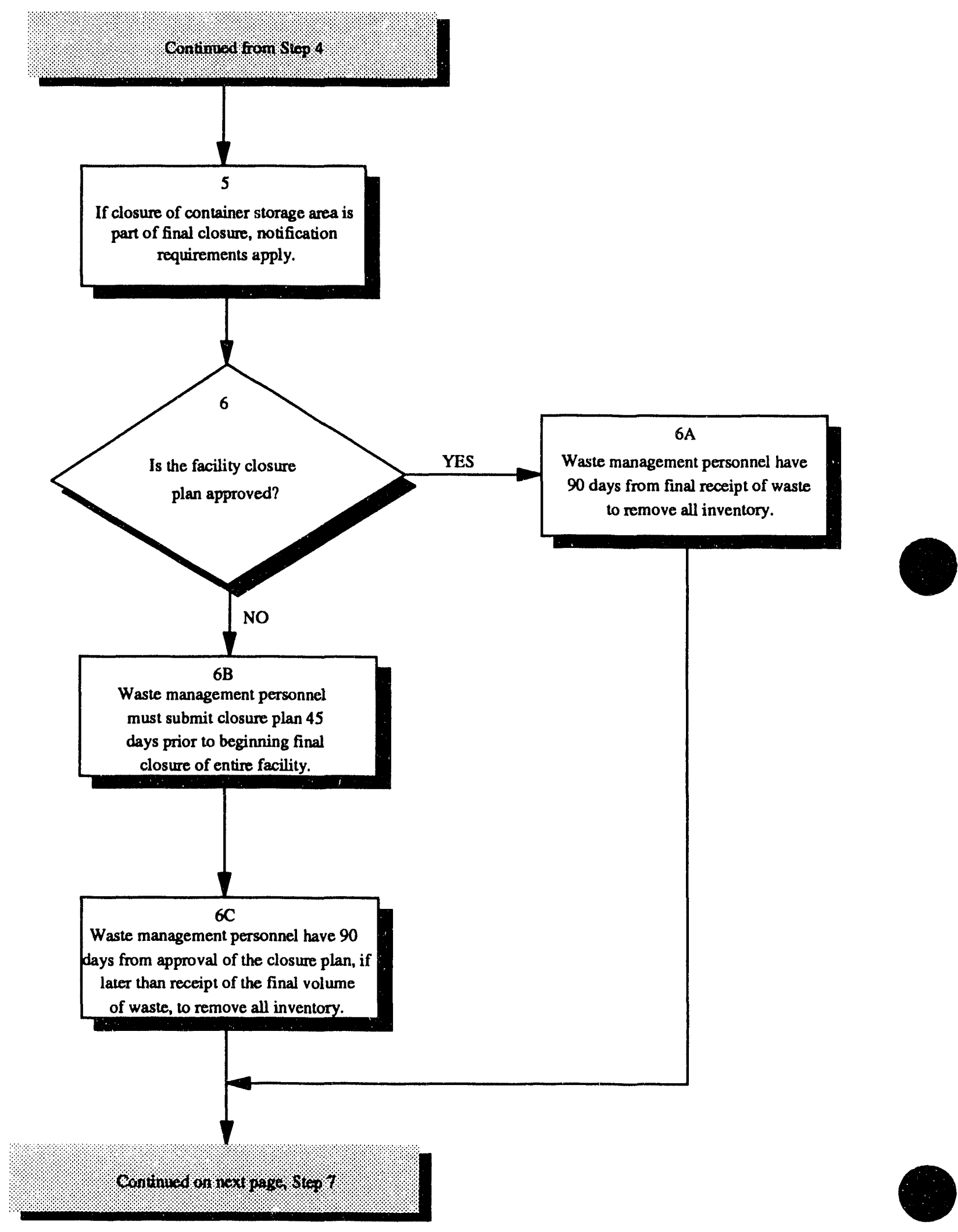
Step 5

Step 6

Step 6A

Step 6B

Step 6C
If closure of the container storage area is part of final closure of a larger facility, waste management personnel must notify the Regional Administrator or State Director 45 days before the day they intend to begin final closure of the facility that contains the container storage area. If the other portions of the facility will continue to operate after closure of the container storage area, waste management personnel may begin closure of the container storage area (i.e., remove hazardous wastes and decontaminated or dismantle equipment) without any notification; however, all activities must be undertaken in accordance with the approved closure plan.

The deadline for removing the inventory of hazardous waste from the container storage is dependent upon whether the facility has an approved closure plan.

If the closure plan for the container storage area has already been approved, waste management personnel have 90 days from the final receipt of hazardous or radioactive mixed waste to complete removal of all hazardous waste inventory from the container storage area. This generally involves sending all containers and their contents off-site; however, if the containers are to be reused or recycled, waste management personnel may empty the containers, stabilize the waste, and handle it separately from the containers. (See also step 7A below for a discussion of possible extensions to this deadline.)

If the container storage area is operating under interim status and does not have an approved closure plan, waste management personnel must submit the closure plan 45 days prior to the beginning of final closure of the entire facility. If other portions of the facility will continue to operate after closure of the container storage area within the facility, waste management personnel are not required to submit a closure plan.

If the closure plan has not been approved by the time the final volume of waste has been received, waste management personnel have 90 days from the approval of the closure plan to remove all inventory from the facility. However, if the facility is not yet undergoing final closure and does not yet have an approved closure plan, it may be prudent to initiate closure activities and dispose of hazardous or radioactive mixed waste inventory prior to obtaining closure plan approval. This generally involves sending all containers and their contents off-site. In some cases, however, waste management personnel may empty the containers, stabilize the waste, and handle it separately from the containers. (See also step 7A below for a discussion of possible extensions to this deadline.) 


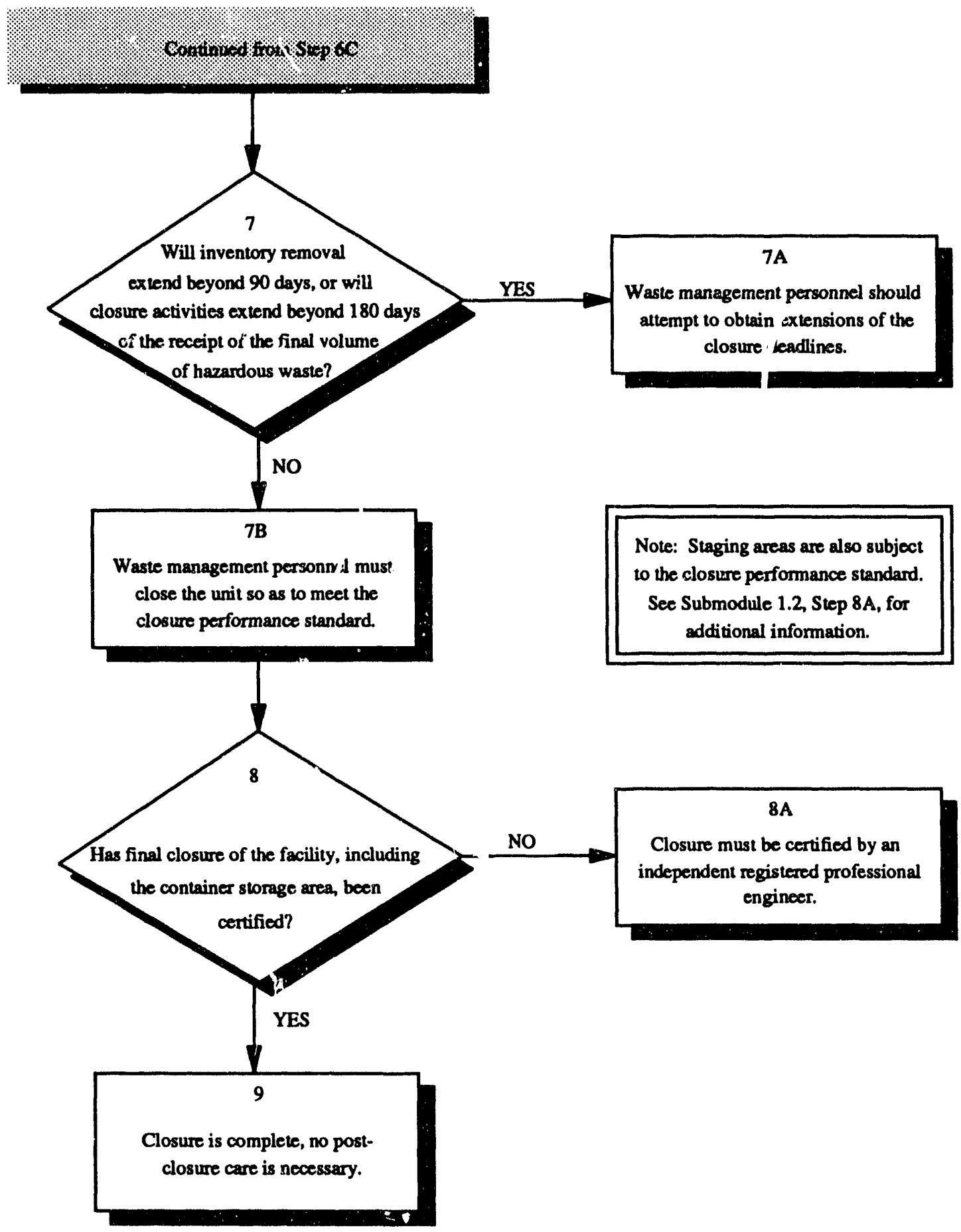


All contaminated containment system components (e.g., bases, structures, and equipment), soils, and subsoils, must be either removed or decontaminated within 180 days of the receipt of the final volume of hazardous or radioactive mixed waste. For interim status facilities without approved closure plans, these deadlines begin upon approval of the closure plan, if that is later than the final receipt of waste (40 CFR 265.113 (b)).

Step 7A These closure deadlines may be extended if waste management personnel can demonstrate that:

- the closure activities will of necessity take longer than the allowable time to complete; or

- the hazardous container storage area has the capacity to receive additional hazardous wastes; and

- there is reasonable likelihood that operation of the container storage area will recommence within one year; and

- $\quad$ closure of the container storage area would be incompatible with continued operation of the site.

If, at the time waste management personnel are developing a clo iure plan, they anticipate that they will need to exceed the 90 - or 180-day deadline(s), they should include in the closure plan a justification for an extension of the deadline(s).

Step 7B The container storage area must be closed in such a manner that it meets the closure performance standard of 40 CFR 264.111 or 265.111. Proper clc sure will minimize the need for further maintenance as well as control, minimize, or eliminate releases from the unit after closure. Waste management personnel must repeatedly clean, wash, or rinse facility structures and equipment uni'. monitoring samples of the last rinse water satisfy the closure performance standard. Residuals resulting from this activity should be treated as hazardous wastes unless waste management personnel can demonstrate that they are not hazardous waste. The regulations also require owners or operators to decontaminate all contaminated equipment, tools, clothing, supplies, etc., involved in operating, maintaining, and closing the unit.

If bases and other container system structures or equipment cannot be decontaminated, they must be removed. Soils underlying the container storage area should be tested at this point to determine the extent of contamination. Any soils that have been determined to contain contaminants in excess of the exposure limits specified in the closure plan must be removed. For more detailed information on how to conduct (losure activities at container storage areas, waste management personnel should consult the references at the end of this submodule.

NOTE: Staging areas at which wastes are accumulated or stored for less than 90 days are subject to the interim status closure performance standard (40 CFR 265.111) and other requirements. See Submodule 1.2, Step $8 A$ for more information on these requirements.

Step 8 Following completion of final closure of a facility, waste management personnel must certify that closure activities have been conducted in accordance with the approved closure plan. If a container storage area has been closed, but other portions of the facility remain in operation, closure certification of the container storage area is not required until final closure. 
The certification must be conducted and signed by an independent registered professional engineer. EPA defines an independent engineer as one who is not a direct employee (i.e., not on the payroll) of DOE or its operating contractor. The closure certification must be sent, by registered mail, to the Regional Administrator or State Director within 60 days of the completion of final closure of the entire facility. Supporting documentation of the certification must be made available to the Regional Administrator or State Director upon request.

Step 9 Upon successful completion and certification of closure of the cortainer storage area, no post-closure care is required. If DOE cannot certify closure, waste management personnel must apply for a post-closure permit and conduct post-closure care.

Post-closire care is unlikely to apply to containers or container storage areas because all container storage areas must be clean closed (40 CFR 264.178). Any releases from containers or container storage areas that preclude clean closure must be addressed through corrective action (see Submodule 4.4, "Corrective Action").

\section{REFERENCES FOR MODULE 5}

1) Closure of Hazardous and Mixed Radioactive Waste Management Units at DOE Facilities, U.S. Department of Energy, Office of Environmental Guidance, RCRA/CERCLA Division, DOE/EGD-RCRA-002/0690, June 1990.

2) Final Report/Guidance Manual: Cost Estimates for Closure and Post-Closure Plans (Subparts $G$ and $H$ ) Volume I - Treatment and Storage Facilities and Volume II - Unit Costs, U.S. Environmental Protection Agency, OSWER Directive No. 9476.00-6, November 1987.

3) Guidance on Stabilization and Closure of U.S. DOE Mixed and Low Level Radioactive Waste Disposal Facilities, U.S. Department of Energy, DOE/LLW-82, June 1990.

4) Guide for Decontaminating Buildings, Structures, and Equipment at Superfund Sites, U.S. Environmental Protection Agency, EPA/600/2-85-028, 1985.

5) Handbook: Remedial Action at Waste Disposal Sites (Revised), U.S. Environmental Protection Agency, EPA/625/6-85-006, October 1985.

6) RCRA Guidance Manual for Subpart G Closure and Post-Closure Care Standards and Subpart H Cost Estimating Requirements, U.S. Environmental Protection Agency, EPA/580-SW-87-010, January 1987.

7) 40 CFR 264 and 265 Subpart G -- Closure and post-closure.

8) 40 CFR 264.178 -. Closure of container storage areas.

9) 40 CFR 265.113 (b) -- Closure; time allowed for closure. 
All contaminated containment system components (e.g., bases, structures, and equipment), soils, and subsoils, must be either removed or decontaminated within 180 days of the receipt of the final volume of hazardous or radioactive mixed waste. For interim status facilities without approved closure plans, these deadlines begin upon approval of the closure plan, if that is later than the final receipt of waste (40 CFR 265.113 (b)).

Step 7A

These closure deadlines may be extended if waste management personnel can demonstrate that:

- the closure activities will of necessity take longer than the allowable time to complete; or

- the hazardous container storage area has the capacity to receive additional hazardous wastes; and

- there is reasonable likelihood that operation of the container storage area will recommence within one year; and

- closure of the container storage area would be incompatible with continued operation of the site.

If, at the time waste management personnel are developing a closure plan, they anticipate that they will need to exceed the 90 - or 180 -day deadline(s), they should include in the closure plan a justification for an extension of the deadline(s).

Step 7B The container storage area must be closed in such a manner that it meets the closure performance standard of 40 CFR 264.111 or 265.111. Proper closure will minimize the need for further maintenance as well as control, minimize, or eliminate releases from the unit after closure. Waste management personnel must repeatedly clean, wash, or rinse facility structures and equipment until monitoring samples of the last rinse water satisfy the closure performance standard. Residuals resulting from this activity should be treated as hazardous wastes unless waste management personnel can demonstrate that they are not hazardous waste. The regulations also require owners or operators to decontaminate all contaminated equipment, tools, clothing, supplies, etc., involved in operating, maintaining, and closing the unit.

If bases and other container system structures or equipment cannot be decontaminated, they must be removed. Soils underlying the container storage area should be tested at this point to determine the extent of contamination. Any soils that have been determined to contain contaminants in excess of the exposure limits specified in the closure plan must be removed. For more detailed information on how to conduct closure activities at container storage areas, waste management personnel should consult the references at the end of this submodule.

NOTE: Staging areas at which wastes are accumulated or stored for less than 90 days are subject to the interim status closure performance standard (40 CFR 265.111) and other requirements. See Submodule 1.2, Step 8 A for more information on these requirements.

Step 8 Following completion of final closure of a facility, waste management personnel must certify that closure activities have been conducted in accordance with the approved closure plan. If a container storage area has been closed, but other portions of the facility remain in operation, ciosure certification of the container storage area is not required until final closure. 
The certification must be conducted and signed by an independent registered professional engineer. EPA defines an independent engineer as one who is not a direct employee (i.e., not on the payroll) of DOE or its operating contractor. The closure certification must be sent, by registered mail, to the Regional Administrator or State Director within 60 days of the completion of final closure of the entire facility. Supporting documentation of the certification must be made available to the Regional Administrator or State Director upon request.

Step 9

Upon successful completion and certification of closure of the container storage area, no post-closure care is required. If DOE cannot certify closure, waste management personnel must apply for a post-closure permit and conduct post-closure care.

Post-closure care is unlikely to apply to containers or container storage areas because ail container storage areas must be clean closed (40 CFR 264.178). Any releases from containers or container storage areas that preclude clean closure must be addressed through corrective action (see Submodule 4.4, "Corrective Action").

\section{REFERENCES FOR MODULE 5}

1) Closure of Hazardous and Mixed Radioactive Waste Management Units at DOE Facilities, U.S. Department of Energy, Office of Environmental Guidance, RCRA/CERCLA Division, DOE/EGD-RCRA-002/0690, June 1990.

2) Final Report/Guidance Manual: Cost Estimates for Closure and Post-Closure Plans (Subparts $G$ and H) Voiume I - Treatment and Storage Facilities and Volume II - Unit Costs, U.S. Environmental Protection Agency, OSWER Directive No. 9476.00-6, November 1987.

3) Guidance on Stabilization and Closure of U.S. DOE Mixed and Low Level Radioactive Waste Disposal Facilities, U.S. Department of Energy, DOE/LLW-82, June 1990.

4) Guide for Decontaminating Buildings, Structures, and Equipment at Superfund Sites, U.S. Environmental Protection Agency, EPA/600/2-85-028, 1985.

5) Handbook: Remedial Action at Waste Disposal Sites (Revised), U.S. Environmental Protection Agency, EPA/625/6-85-006, October 1985.

6) RCRA Guidance Manual for Subpart G Closure and Post-Closure Care Standards and Subpart H Cost Estimating Requirements, U.S. Environmental Protection Agency, EPA/580-SW-87-010, January 1987.

7) 40 CFR 264 and 265 Subpart G -- Closure and post-closure.

8) 40 CFR 264.178 -- Closure of container storage areas.

9) 40 CFR 265.113 (b) -- Closure; time allowed for closure. 


\section{ATTACHMENT A}

\section{RCRA CONTAINER REGULATIONS}


[Title]

[Seal]

(2) The following is an example of the certification of acknowledgement which must accompany the trust agreement for a trust fund as specified in $\$ \$ 264.147(j)$ or $265.147(j)$ of this chapter. State requirements may differ on the proper content of this acknowledgement.

State of

County of

On this [date], before me personally came [owner or operator] to me known, who, being by me duly sworn, did depose and say that she/he resides at [address], that she/he is [title] of [corporation], the corporation described in and which executed the above instrument; that she/he knows the seal of said corporation; that the seal affixed to such instrument is such corporate seal; that it was so affixed by order of the Board of Directors of said corporation, and that she/he signed her/his name thereto by like order.

[Signature of Notary Public]

[Approved by the Office of Management and Budget under control number 2000-0445, for paragraphs (g), (i), and (j)]

[47 FR 15059, Apr. 7, 1982, as amended at 47 FR 16556, Apr. 16, 1982; 47 FR 17989, Apr. 27, 1982; 47 FR 19995, May 10, 1982; 47 FR 28627, July 1, 1982; 51 FR 16450 , May 2, 1986; 51 FR 25354, July 11, 1986; S2 FR 44320 , Nov. 18, 1987]

\section{Subpart I-Use and Management of Containers}

Source: 46 FR 2866, Jan. 12, 1981, unless otherwise noted.

\section{$\$ 264.170$ Applicability.}

The regulations in this subpart apply to owners and operators of all hazardous waste facilities that store containers of hazardous waste, except as \$264.1 provides otherwise.

[Comment: Under \$261.7 and \$261.33(c), if a hazandous waste is emptied from a container the residue remaining in the container is not considered a hazardous waste if the container is "empty" as defined in \$261.7. In that event, management of the container is exempt from the requirements of this subpart.]

\section{$\$ 264.171$ Condition of containers.}

If a container holding hazardous waste is not in good condition (e.g., severe rusting, apparent structural defects) or if it begins to leak, the owner or operator must transfer the hazardous waste from this container to a container that is in good condition or manage the waste in some other way that complies with the requirements of this part.

\section{\$264.172 Compatibility of waste with containers.}

The owner or operator must use a container made of or lined with materials which will not react with, and are otherwise compatible with, the hazardous waste to be stored, so that the ability of the container to contain the waste is not impaired.

\section{\$264.173 Management of containers.}

(a) A container holding hazardous waste must always be closed during storage, except when it is necessary to add or remove waste.

(b) A container holding hazardous waste must not be opened, handled, or stored in a manner which may rupture the container or cause it to leak.

[Comment: Reuse of containers in transportation is governed by U.S. Department of Transportation regulations including those set forth in 49 CFR 173.28.]

\section{\$264.174 Inspections.}

At least weekly, the owner or operator must inspect areas where containers are stored, looking for leaking containers and for deterioration of containers and the containment system caused by corrosion or other factors.

[Comment: See 8\$264.15(c) and 264.171 for remedial action required if deterioration or leaks are detected.]

\section{$\$ 264.175$ Containment.}

(a) Container storage areas must have a containment system that is designed and operated in accordance with paragraph (b) of this section, except as otherwise provided by paragraph (c) of this section.

(b) A containment system must be designed and operated as follows:

(1) A base must underlie the containers which is free of cracks or gaps and is sufficiently impervious to contain leaks, spills, and accumulated precipitation until the collected material is detected and removed;

(2) The base must be sloped or the containment system must be otherwise designed and operated to drain and remove liquids resulting from leaks, spills, or precipitation, unless the containers are elevated or are otherwise protected from contact with accumulated liquids;

(3) The containment system must have sufficient capacity to contain $10 \%$ of the volume of containers or the volume of the largest container, whichever is greater. 
Containers that do not contain free liquids need not be considered in this determination;

(4) Run-on into the containment system must be prevented unless the collection system has sufficient excess capacity in addition to that required in paragraph (b)(3) of this section to contain any run-on which might enter the system; and

(5) Spilled or leaked waste and accumulated precipitation must be removed from the sump or collection area in as timely a manner as is necessary to prevent overflow of the collection system.

[Comment: If the collected material is a hazardous waste under Part 261 of this Chapter, it must be managed as a hazardous waste in accordance with all applicable requirements of Parts 262 through 266 of this chapter. If the collected material is discharged through a point source to waters of the United States, it is subject to the requirements of section $\mathbf{4 0 2}$ of the Clean Water Act, as amended.]

(c) Storage areas that store containers holding only wastes that do not contain free liquids need not have a containment system defined by paragraph (b) of this section, except as provided by paragraph (d) of this section or provided that:

(1) The storage area is sloped or is otherwise designed and operated to drain and remove liquid resulting from precipitation, or

(2) The containers are elevated or are otherwise protected from contact with accumulated liquid.

(d) Storage areas that store containers holding the wastes listed below that do not contain free liquids must have a containment system defined by paragraph (b) of this section:

(1) FO20, FO21, FO22, FO23, FO26, and FO27.

(2) [Reserved]

[46 FR 55112, Nov. 6, 1981, as amended at 50 FR 2003 . Jan. 14, 1985]

\subsection{Special requirements for} ignitable or reactive waste.

Containers holding ignitable or reactive waste must be located at least 15 meters (50 feet) from the facility's property line.

[Comment: See \$264.17(a) for additional requirements.]

\section{\$264.177 Special requirements for incompatible wastes}

(a) Incompatible wastes, or incompatible wastes and materials (see Appendix V for examples), must not be placed in the same container, unless $\$ 264.17(b)$ is complied with. (b) Hazardous waste must not be placed in an unwashed container that previously held an incompatible waste or material.

[Comment: As required by \$264.13, the waste analysis plan must include analyses needed to comply with 8264.177. Also, 8264.17(c) requires wastes analyses, trial tests or other documentation to assure compliance with $\$ 264.17$ (b). As required by $\$ 264.73$, the owner or operator must place the results of each waste analysis and trial test, and any documented information, in the operating record of the facility.]

(c) A storage container holding a hazardous waste that is incompatible with any waste or other materials stored nearby in other containers, piles, open tanks, or surface impoundments must be separated from the other materials or protected from them by means of a dike, berm, wall, or other device.

[Comment: The purpose of this section is to prevent fires, explosions, gaseous emission, leaching, or other discharge of hazardous waste or hazardous waste constituents which could result from the mixing of incompatible wastes or materials if containers break or leak.]

\section{\$264.178 Closure.}

At closure, all hazardous waste and hazardous waste residues must be removed from the containment system. Remaining containers, liners, bases, and soil containing or contaminated with hazardous waste or hazardous waste residues must be decontaminated or removed.

[Comment: At closure, as throughout the operating period, uniess the owner or operator can demonstnte in accordance with 8261.3(d) of this chapter that the solid waste removed from the containment system is not a hazandous waste, the owner or operator becomes a generator of hazandous waste and must manage it in sccordance with all applicable requirements of Parts 262 through 266 of this chapter].

\section{Subpart J-Tank Systems}

Source: 51 FR 25472, July 14, 1986, unless otherwise noted.

\section{$\$ 264.190$ Applicability.}

The requirements of this subpart apply to owners and operators of facilities that use tank systems for storing or treating hazardous waste except as otherwise provided in paragraphs (a), (b), and (c) of this section or in \$264.1 of this part.

(a) Tank systems that are used to store or treat hazardous waste which contains no free liquids and are situated inside a building with an impermeable floor are exempted from the requirements in \$264.193. To demonstrate the absence or presence of free liquids in the stored/treated waste, EPA Method 9095 
consider other factors as he deems appropriate. The owner or operator must submit to the Regional Administrator evidence of the establishment of the mechanism together with a letter requesting that the State-required mechanism be considered acceptable for meeting the requirements of this subpart. The submission must include the following information: The facility's EPA Identification Number, name, and address, and the amount of funds for closure or post-closure care or liability coverage assured by the mechanism. The Regional Administrator will notify the owner or operator of his determination regarding the mechanism's acceptability in lieu of financial mechanisms specified in this subpart. The Regional Administrator may require the owner or operator to submit additional information as is deemed necessary to make this determination. Pending this determination, the owner or operator will be deemed to be in compliance with the requirements of $\$ 265.143, \S 265.145$, or $\$ 265.147$, as applicable.

(b) If a State-required mechanism is found acceptable as specified in paragraph (a) of this section except for the amount of funds available, the owner or operator may satisfy the requirements of this subpart by increasing the funds available through the State-required mechanism or using additional financial mechanisms as specified in this subpart. The amount of funds available through the State and Federal mechanisms must at least equal the amount required by this subpart.

\subsection{State assumption of responsibility.}

(a) If a State either assumes legal responsibility for an owner's or operator's compliance with the closure, post-closure care, or liability requirements of this part or assures that funds will be available from State sources to cover those requirements, the owner or operator will be in compliance with the requirements of $\$ 265.143, \$ 265.145$, or $\$ 265.147$ if the Regional Administrator determines that the State's assumption of responsibility is at least equivalent to the financial mechanisms specified in this subpart. The Regional Administrator will evaluate the equivalency of State guarantees principally in terms of (1) certainty of the availability of funds for the required closure or post-closure care activities or liability coverage and (2) the amount of funds that will be made available. The Regional Administrator may also consider other factors as he deems appropriate. The owner or operator must submit to the Regional Administrator a letter from the State describing the nature of the State's assumption of responsibility together with a letter from the owner or operator requesting that the State's assumption of responsibility be considered acceptable for meeting the requirements of this subpart. The letter from the State must include, or have attached to it. the following information: The facility's EPA Identification Number, name, and address, and the amount of funds for closure or post-closure care or liability coverage that are guaranteed by the State. The Regional Administrator will notify the owner or operator of his determination regarding the acceptability of the State's guarantee in lieu of financial mechanisms specified in this subpart. The Regional Administrator may require the owner or operator to submit additional information as is deemed necessary to make this determination. Pending this determination, the owner or operator will be deemed to be in compliance with the requirements of $\$ \$ 265.143,265.145$, or 265.147, as applicable.

(b) If a State's assumption of responsibility is found acceptable as specified in paragraph (a) of this section except for the amount of funds available, the owner or operator may satisfy the requirements of this subpart by use of both the State's assurance and additional financial mechanisms as specified in this subpart. The amount of funds available through the State and Federal mechanisms must at least equal the amount required by this subpart.

\section{Subpart I-Use and Management of Containers}

\section{$\$ 265.170$ Applicability.}

The regulations in this subpart apply to owners and operators of all hazardous waste facilities that store containers of hazardous waste, except as \$265.1 provides otherwise.

\subsection{Condition of containers.}

If a container holding hazardous waste is not in good condition, or if it begins to leak, the owner or operator must transfer the hazardous waste from this container to a container that is in good condition, or manage the waste in some other way that complies with the requirements of this part. 


\section{\$265.172 Compatibility of waste with container.}

The owner or operator must use a container made of or lined with materials which will not react with, and are otherwise compatible with, the hazardous waste to be stored, so that the ability of the container to contain the waste is not impaired.

\section{\$265.173 Management of containers.}

(a) A container holding hazardous waste must always be closed during storage, except when it is necessary to add or remove waste.

(b) A container holding hazardous waste must not be opened, handled, or stored in a manner which may rupture the container or cause it to leak.

[Comment: Re-use of containers in transportation is governed by U.S. Department of Transportation regulations, including those set forth in $49 \mathrm{CFR}$ 173.28.] [45 FR 33232, May 19, 1980, as amended at 45 FR 78529. Nov. 25, 1980]

\section{$\$ 265.174$ Inspections.}

The owner or operator must inspect areas where containers are stored, at least weekly, looking for leaks and for deterioration caused by corrosion or other factors.

[Comment: See \$265.171 for remedial action required if deterioration or leaks are detected.]

\section{$\$ 265.175$ [Reserved]}

\section{$\$ 265.176$ Special requirements for ignitable or reactive waste.}

Containers holding ignitable or reactive waste must be located at least 15 meters (50 feet) from the facility's property line.

[Comment: See \$265.17(a) for additional requirements.]

\section{$\$ 265.177$ Special requirements for incompatible wastes.}

(a) Incompatible wastes, or incompatible wastes and materials, (see Appendix $V$ for examples) must not be placed in the same container, unless $\$ 265.17(b)$ is complied with.

(b) Hazardous waste must not be placed in an unwashed container that previously held an incompatible waste or material (see Appendix V for examples), unless $\$ 265.17$ (b) is complied with.

(c) A storage container holding a hazardous waste that is incompatible with any waste or other materials stored nearby in other containers, piles, open tanks, or surface impoundments must be separated from the other materials or protected from them by means of a dike, berm, wall, or other device.

[Comment: The purpose of this is to prevent fires, explosions, gaseous emissions, leaching, or other discharge of hazardous waste or hazardous waste constituents which could result from the mixing of incompatible wastes or materials if containers break or leak.]

\section{Subpart J-Tank Systems}

Source: 51 FR 25479, July 14, 1986, unless otherwise noted.

\subsection{Applicability.}

The requirements of this subpart apply to owners and operators of facilities that use tank systems for storing or treating hazardous waste except as otherwise provided in paragraphs (a), (b), and (c) of this section or in \$265.1 of this part.

(a) Tank systems that are used to store or treat hazardous waste which contains no free liquids and that are situated inside a building with an impermeable floor are exempted from the requirements of $\$ 265.193$. To demonstrate the absence or presence of free liquids in the stored/ treated waste, EPA Method 9095 (Paint Filter Liquids Test) as described in "Test Methods for Evaluating Solid Wastes, Physical/Chemical Methods" (EPA Publication No. SW-846) must be used.

(b) Tank systems, including sumps, as defined in $\$ 260.10$, that serve as part of a secondary containment system to collect or contain releases of hazardous wastes are exempted from the requirements in \$265.193(a).

(c) Tanks, sumps, and other collection devices used in conjunction with drip pads, as defined in $\$ 260.10$ of this chapter and regulated under 40 CFR part 265 subpart $W$, must meet the requirements of this subpart.

IInformation collection requirement contained in paragraph (a) was approved by the Office of Management and Budget under control number 2050-0050]

\section{\$265.191 Assessment of existing tank system's integrity.}

(a) For each existing tank system that does not have secondary containment meeting the requirements of $\$ 265.193$, the owner or operator must determine that the tank system is not leaking or is unfit for use. Except as provided in paragraph (c) of this section, the owner or operator must obtain and keep on file at the facility a written assessment reviewed and certified by an independent, qualified, registered professional engineer in

A-5 

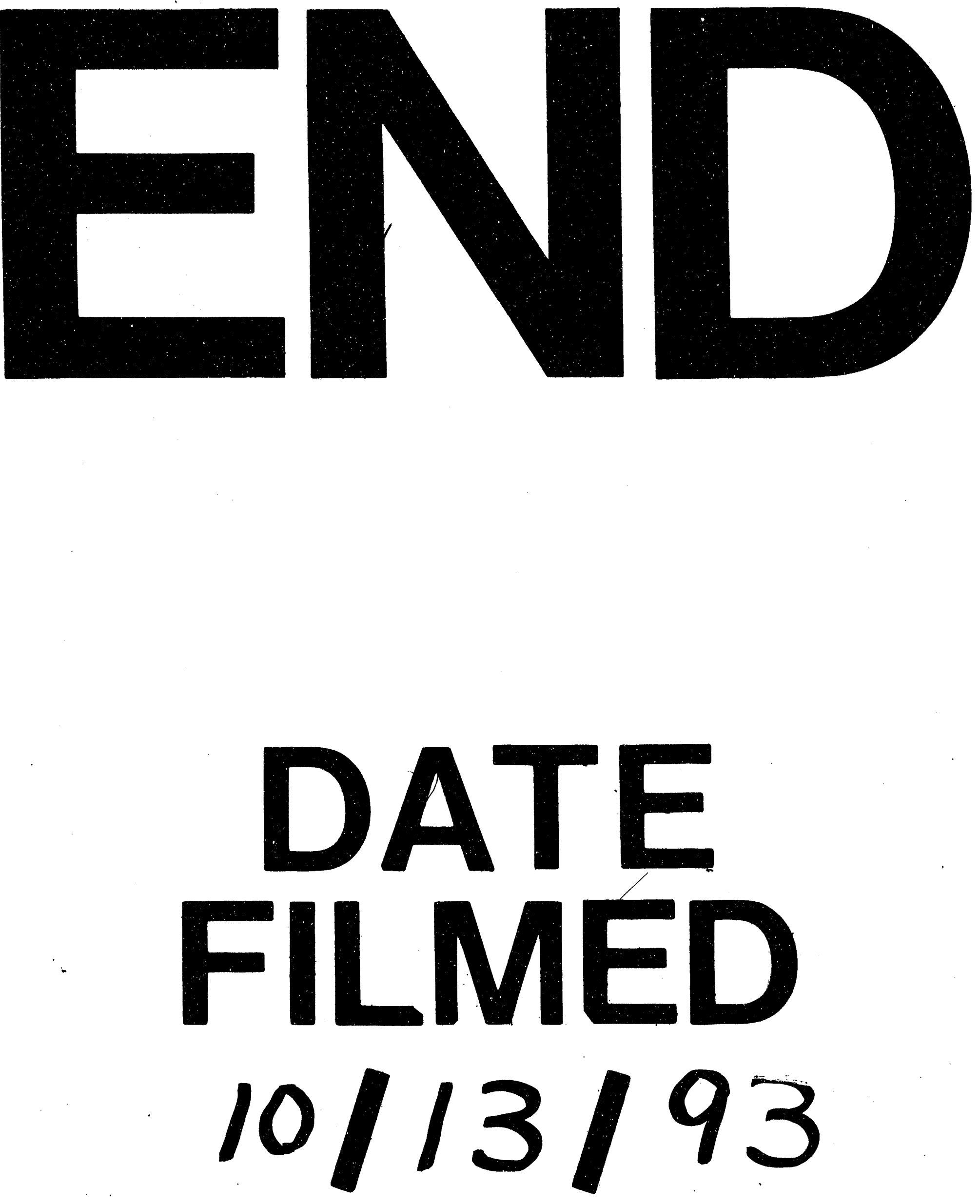

1 
